RODRIGO DE GODOY VASCONCELLOS

\title{
EXTENSÃO DO PERÍODO DE GARANTIA PARA VEÍCULOS POPULARES
}


RODRIGO DE GODOY VASCONCELLOS

\section{EXTENSÃO DO PERÍODO DE GARANTIA PARA VEÍCULOS POPULARES}

Trabalho de Conclusão de Curso apresentado à Escola Politécnica da Universidade de São Paulo para obtenção do título de Mestre Profissional em Engenharia Automotiva.

Área de Concentração:

Engenharia Automotiva

Orientador: Professor Doutor Marcelo

Massarani

São Paulo 
Este exemplar foi revisado e alterado em relação à versão original, sob responsabilidade única do autor e com a anuência de seu orientador.

São Paulo, 27 de abril de 2007.

Assinatura do autor

Assinatura do orientador

FICHA CATALOGRÁFICA

Vasconcellos, Rodrigo de Godoy

Extensão do período de garantia para veículos populares / R.

de G. Vasconcellos. -- ed.rev. -- São Paulo, 2007. $118 \mathrm{p}$.

Trabalho de conclusão de curso (Mestrado Profissionalizante em Engenharia Automotiva) - Escola Politécnica da Universidade de São Paulo.

1.Veículos populares (Garantia) I.Universidade de São Paulo. Escola Politécnica II.t. 
Dedico este trabalho à minha esposa Ingrid, pelos momentos em que não pude the dar a devida atenção. Não menos importantes são os meus pais, Claudete e Oduvaldo, pelo constante incentivo para que os seus filhos sempre continuem estudando. 


\section{AGRADECIMENTOS}

Agradeço ao Professor Doutor Marcelo Massarani, pela motivação, apoio e constante incentivo durante o período de desenvolvimento deste trabalho.

Os meus sinceros agradecimentos ao meu gerente Renato Bibo, pelo suporte prestado durante o meu período de Mestrado.

Finalmente, a todos que colaboraram, direta ou indiretamente, na execução deste trabalho. 


\section{RESUMO}

Desde a criação, na década de 90 , dos veículos populares, cuja característica principal é a utilização de motores até 1.0 litro de capacidade volumétrica, tem influenciado fortemente o mercado de veículos brasileiro, tendo mais 50\% de participação no market share desde o inicio de suas vendas. Diante do atual cenário da Indústria Automotiva Brasileira, este trabalho tem como objetivo estudar a possibilidade de estender o período de garantia em veículos populares para 36 meses como vantagem competitiva de mercado. O modelo proposto, com o suporte de conceitos de confiabilidade e de falhas de produtos, consiste em utilizar os dados de falhas de campo para estimar os gastos em garantia após 36 meses de exposição no campo, o que permite analisar as suas vantagens e desvantagens para a tomada de decisão por parte da empresa. Este estudo recomenda também um plano de validação técnica para a extensão de garantia que consiste em submeter veículos provenientes do campo de provas da empresa a uma quilometragem elevada para verificação da durabilidade e confiabilidade de seus componentes dentro do período de 36 meses de exposição no campo. O plano de implementação da extensão da garantia para veículos populares recomenda a introdução de dois anos de garantia no mercado de forma que o produto seja monitorado quanto ao seu comportamento de falhas e possíveis reclamações dos clientes, gerando informações para que a empresa decida quanto à manutenção do período de garantia para três anos. Finalmente a extensão do período de garantia para veículos populares é possível, desde que todos os níveis da organização estejam comprometidos e que seja feito um planejamento prévio utilizando-se de todos os dados e recursos disponíveis para a tomada de decisão.

Palavras Chave: Garantia. Banco de dados de falhas de campo. Falhas. 


\begin{abstract}
Since their creation in the beginning of 90 decade, the popular vehicles, which main characteristic is the use of engines up to 1.0 liter of volumetric capacity, have strongly influenced the Brazilian market of vehicles, having more than $50 \%$ of participation in the market share since the beginning of their sales. Based on the current scenario of the Brazilian Automotive Industry, this work has the objective of suggesting a model to evaluate the warranty extension for popular vehicles to 36 months as a market competitive advantage. The study, supported by reliability and product failures theoretical concepts, consists of using the field failure data to estimate the warranty cost in 36 months exposure in the field, which allows analyzing its advantages and disadvantages for company decision making. This study also recommends a technical validation plan for warranty extension that consists of submitting vehicles from the company proving ground to high mileages to verify their parts durability and reliability in 36 months of field exposure. The warranty extension implementation plan recommends the implementation of two years warranty in the market, monitoring the failures and customers complaints during this period to generate information for company for decision making to implement the three years warranty. Finally, the warranty extension for popular vehicles is possible since all levels of the organization are committed and a previous plan must be done using all the information and resources available for company decision making.
\end{abstract}

Keywords: Warranty. Field failure data base. Failures 


\section{LISTA DE ILUSTRAÇÕES}

Figura 1 - Tipos de Garantias (Hart, 1996, apud Figueiredo 2005)........................24

Figura 2 - Política de Garantia Pró-Rata (Berke \& Zaino, 1991)............................28

Figura 3 - Política de Garantia Combinada (Berke \& Zaino, 1991)........................28

Figura 4 - Benefícios de Uma Boa Garantia (Wirtz, 1998, apud

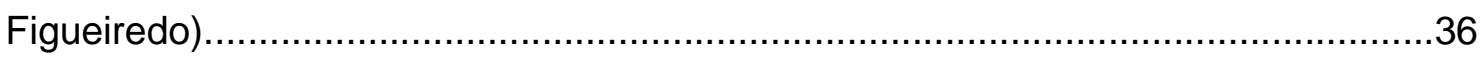

Figura 5 - Fluxo de Desenvolvimento e Implementação de Garantias (Kandampully e

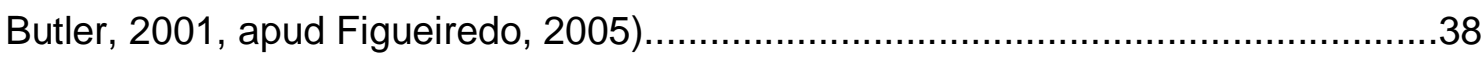

Figura 6 - Confiabilidade e Custos do Ciclo de Vida (Connor, 2001)......................50

Figura 7 - Representação Gráfica da Curva da Banheira (Connor, 2001).................52

Figura 8 - Método de Classificação das Falhas (Blashe, 1991)...............................53

Figura 9 - Valor da Informação Diminui com o Tempo e o Risco Aumenta (Alaverdi e Fathi, 2006)

Figura 10 - Custo de Garantia Acumulado x Unidades Vendidas (Barkai,

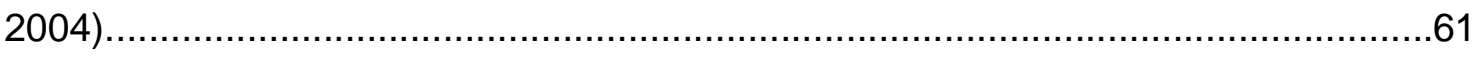

Figura 11 - IPTV 12 MIS x Ano de Fabricação............................................ 75

Figura 12 - Custo de Garantia x Ano de Fabricação.........................................75

Figura 13 - Custo de Garantia x Fator de Conversão........................................85

Figura 14 - Cronograma do Plano de Implementação da Extensão do Período de Garantia Para Veículos Populares........................................................111 


\section{LISTA DE TABELAS}

Tabela 1 - Participação dos Veículos Populares no Mercado Brasileiro (Fonte: Anuário da Indústria Automotiva Brasileira, 2006).............................................14

Tabela 2 - Custo de Garantia por Veículo por Meses de Exposição no Campo (12

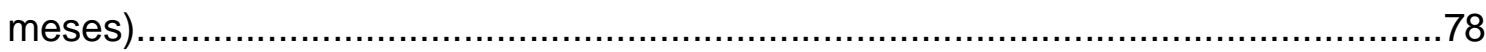

Tabela 3 - Custo de Garantia por Veículo por Meses de Exposição no Campo (8

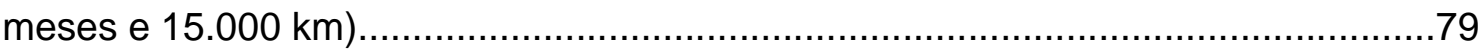

Tabela 4 - Custo de Garantia por Veículo para 8 Meses de Exposição no Campo e $15.000 \mathrm{~km}$ corrigido

Tabela 5 - Custo de Garantia por Veículo para 24 Meses de Exposição no Campo. 81

Tabela 6 - Custo de Garantia por Veículo para 36 Meses de Exposição no Campo. 82

Tabela 7 - Custo de Garantia por Veículo para 12, 24 e 36 Meses de Exposição no Campo. 83

Tabela 8 - Fluxo de Atividades para Execução do Modelo para Extensão do Período de Garantia. .83

Tabela 9 - Dez Maiores Reclamações por Custo. .86

Tabela 10 - Número de Amostras por Probabilidade Binomial (Fonte: La Mothe, 2002) 


\section{LISTA DE ABREVIATURAS E SIGLAS}

$\begin{array}{ll}\text { ANFAVEA } & \text { Associação Nacional dos Fabricantes de Veículos Automotores } \\ \text { CPV } & \text { Custo de Garantia por Veículo } \\ \text { FC } & \text { Fator de Conversão } \\ \text { Gipa } & \text { Grupo Interprofissional de Produtos e Serviços Automóvel } \\ \text { IPI } & \text { Imposto sobre Produtos Industrializados } \\ \text { IPTV } & \text { Incidences per Thousand Vehicles } \\ \text { NIV } & \text { Número de Identificação do Veículo } \\ \text { QAS } & \text { Quality Audit Survey } \\ \text { UM\$ } & \text { Unidades Monetárias }\end{array}$




\title{
LISTA DE SÍMBOLOS
}

\author{
$\mathrm{f}(\mathrm{t}) \quad$ Função densidade de probabilidade \\ $n \quad$ Número de Amostras \\ $p_{a} \quad$ Probabilidade de Aceitação \\ c Número de Falhas Toleráveis \\ $p \quad$ Taxa de Falha Atual \\ $t \quad$ Tempo
}




\section{SUMÁRIO}

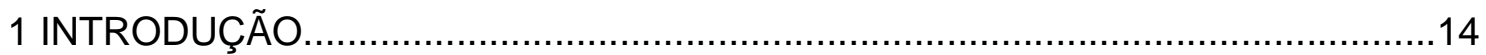

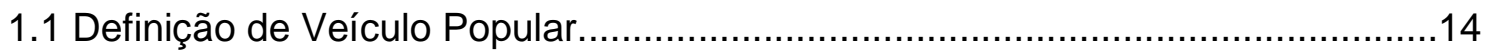

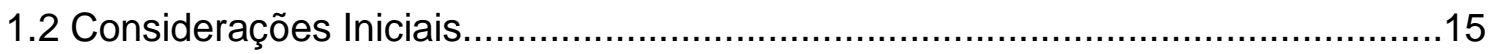

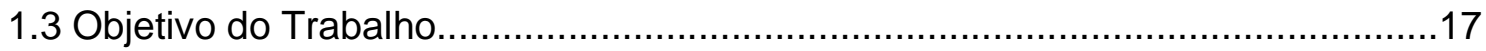

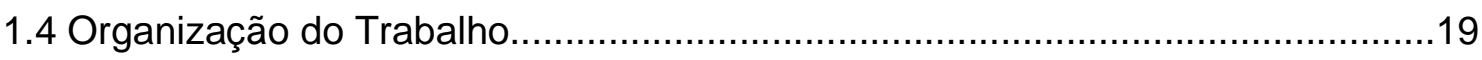

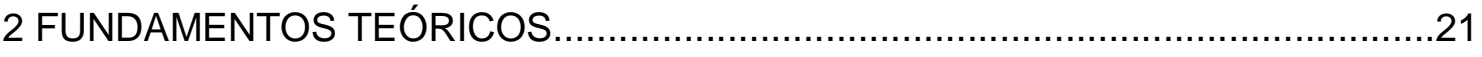

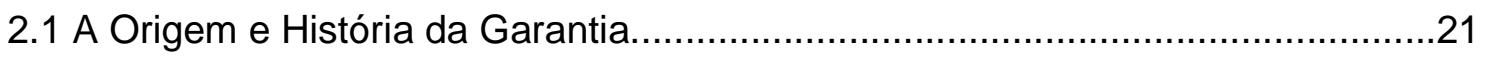

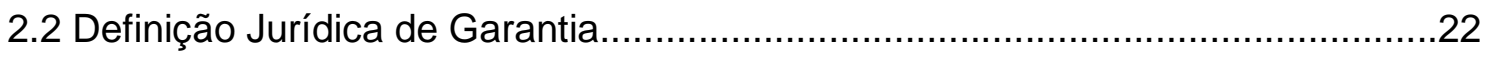

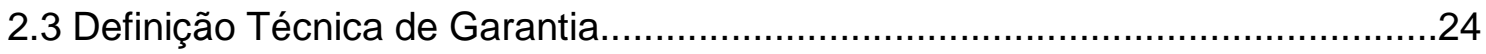

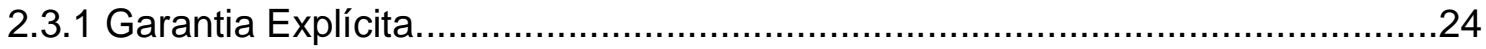

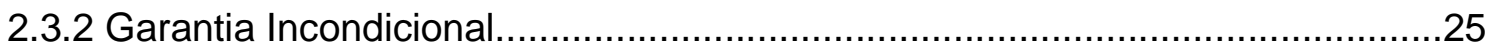

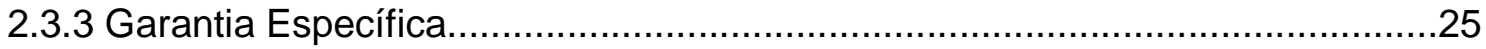

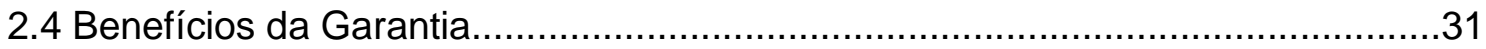

2.4.1 A Garantia como Ferramenta de Marketing ..................................................

2.4.2 A Garantia como Ferramenta da Gestão e Melhoria da Qualidade...................32

2.5 Desenvolvimento e Implementação de uma Garantia..........................................37

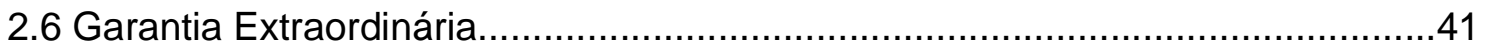

2.7 Definição de Garantia Quanto a Custos..........................................................42

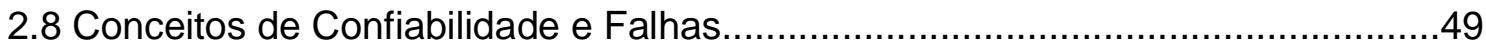

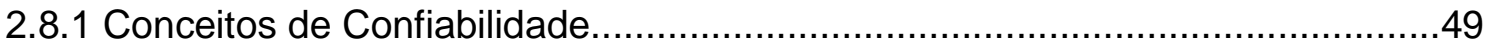

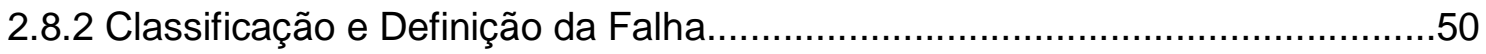

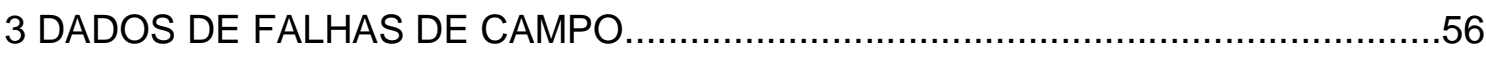

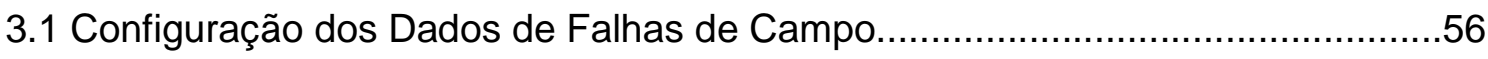

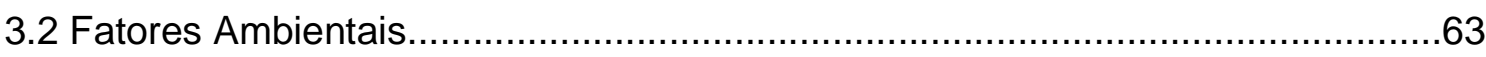

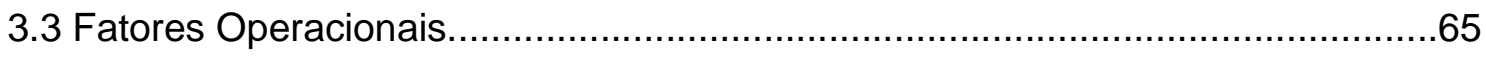

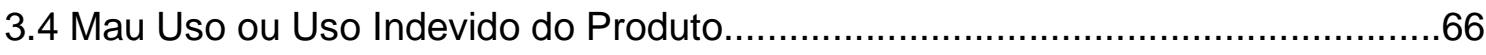

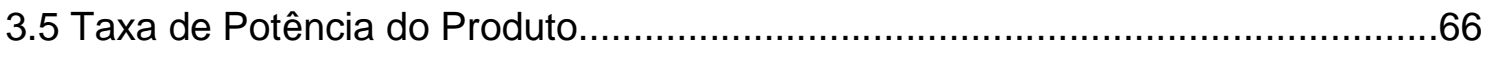

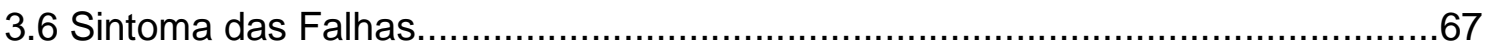

3.7 Diagnóstico Observado Durante o Reparo........................................................67

3.8 Banco de Dados de Falhas de Campo............................................................68 
4 CÁLCULO DO CUSTO DE GARANTIA PARA VEÍCULOS POPULARES APÓS 36

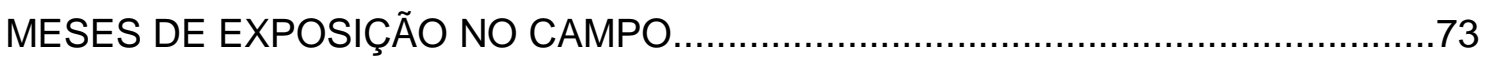

4.1 Determinação do Custo de Garantia no Preço Final do Veículo............................73

4.2 Cálculo do Custo de Garantia Após 24 e 36 Meses de Exposição no Campo. . .77

4.3 Análise Crítica do Método para Cálculo do Custo de Garantia Após 36 Meses de

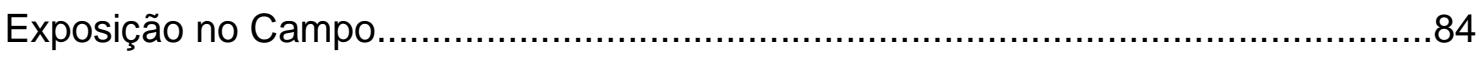

5 PROPOSTA DE IMPLEMENTAÇÃO DA EXTENSÃO DO PERÍOdO DE GARANTIA PARA VEÍCULOS POPULARES. 88

5.1 Plano de Validação Técnica da Extensão do Período de Garantia para Veículos Populares 88

5.1.1 Determinação do Tamanho de Amostra dos Veículos Monitorados. .89

5.1.2 Intervalo para a Inspeção Periódica dos Veículos Monitorados........................91

5.1.3 Definição de Itens a Serem Verificados nas Inspeções Periódicas....................92

5.1.4 Origem dos Veículos que Serão Inspecionados..........................................92

5.1.4.1 Utilização de Veículos Provenientes do Campo de Provas da

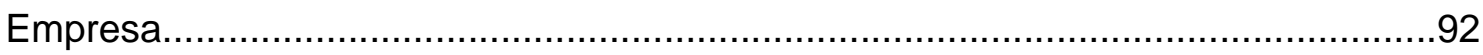

5.1.4.2 Utilização de Veículos Provenientes da Frota da Empresa............................94

5.1.4.3 Utilização de Veículos Provenientes de Frotas de Outras Empresas. .95

5.1.4.4 Utilização de Veículos Provenientes de Frotas de Empresas Locadoras de Veículos. 97

5.1.4.5 Utilização de Veículos de Motoristas de Praça.............................................99

5.1.4.6 Utilização de Veículos de Clientes da Empresa........................................100

5.2 Análise Crítica do Plano de Validação Técnica da Extensão do Período de

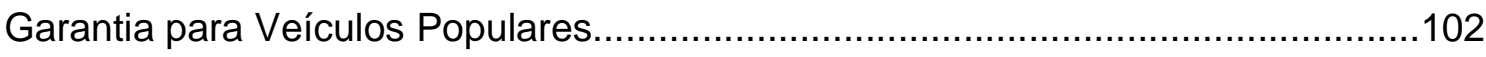

5.3 Plano de Implementação da Extensão do Período de Garantia para Veículos Populares. 104

5.3.1 Primeira Fase - Comunicação e Treinamento...............................................104

5.3.1.1 Comunicação e Treinamento dos Funcionários da Empresa........................105

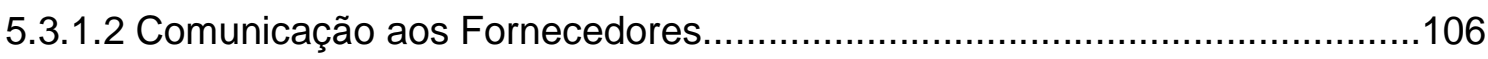

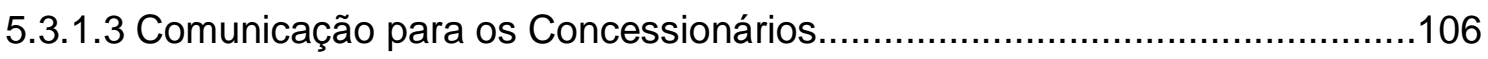

5.3.1.4 Treinamento para os Funcionários dos Concessionários............................106

5.3.1.5 Divulgação e Exposição na Mídia..........................................................107 
5.3.2 Segunda Fase - Vigência da Garantia de Dois Anos.

108

5.3.2.1 Monitoramento das Falhas Ocorridas em Durabilidade Durante o Segundo

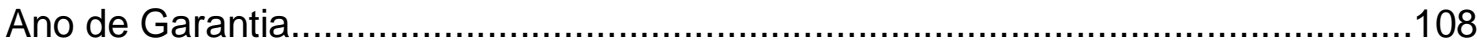

5.3.3 Tomada de Decisão Quanto à Extensão do Período de Garantia Para Três

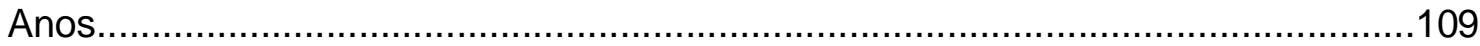

5.3.4 Terceira Fase - Vigência da Garantia de Três Anos......................................109

5.3.4.1 Monitoramento das Falhas Ocorridas Durante o Terceiro Ano de Vigência da Garantia. 110

5.3.5 Tomada de Decisão Quanto à Manutenção do Período de Garantia Para Três Anos 110

6. CONCLUSÕES E CONSIDERAÇÕES FINAIS 112

7. REFERÊNCIAS BIBLIOGRÁFICAS. 116 


\section{INTRODUÇÃO}

\subsection{Definição de Veículo Popular}

O conceito de veículo popular foi criado em 1993, em que o objetivo era oferecer um produto básico para atrair consumidores de menor renda. O projeto teve incentivo do governo, que fixou a alíquota do Imposto sobre Produtos Industrializados (IPI) para veículos populares em $0,1 \%$. Os modelos mais baratos, Fiat Uno e Volkswagen Fusca, custavam naquele ano, aproximadamente $\mathrm{R} \$ 7.200,00$ (cerca de US\$ 7,000.00). Atualmente o IPI do veículo popular é de 9,0\%, ainda inferior ao dos demais modelos, que inicia em 15,0\%. A criação do veículo popular fez com que as vendas da indústria automotiva aumentassem, chegando ao recorde de 1,9 milhões de unidades em 1997. Assim, o mercado de veículos populares é o que responde pela maior fatia de vendas das montadoras nos últimos anos desde a sua criação em 1990, conforme pode ser visto na Tabela 1 logo abaixo, segundo o Anuário da Indústria Automotiva Brasileira (2006), da Associação Nacional dos Fabricantes de Veículos Automotores (ANFAVEA):

\begin{tabular}{cccc}
$\begin{array}{c}\text { Tabela } 1-\text { Participação dos Veículos Populares no Mercado Brasic } \\
\text { Ano de } \\
\text { Produção }\end{array}$ & $\begin{array}{c}\text { Automoveıs } \\
\text { de 1000 cc }\end{array}$ & $\begin{array}{c}\text { Total de } \\
\text { Automóveis }\end{array}$ & $\begin{array}{c}\text { Partıcıpaçāo } \\
\text { (\%) }\end{array}$ \\
\hline 1990 & 23.013 & 532.906 & $4,3 \%$ \\
1991 & 67.299 & 597.892 & $11,3 \%$ \\
1992 & 92.959 & 596.964 & $15,6 \%$ \\
1993 & 243.511 & 903.828 & $26,9 \%$ \\
1994 & 450.925 & 1.127 .673 & $40,0 \%$ \\
1995 & 602.098 & 1.407 .073 & $42,8 \%$ \\
1996 & 703.118 & 1.405 .545 & $50,0 \%$ \\
1997 & 880.119 & 1.569 .727 & $56,1 \%$ \\
1998 & 748.474 & 1.211 .885 & $61,8 \%$ \\
1999 & 625.445 & 1.011 .847 & $61,8 \%$ \\
2000 & 777.604 & 1.176 .774 & $66,1 \%$ \\
2001 & 920.389 & 1.295 .096 & $71,1 \%$ \\
2002 & 820.135 & 1.229 .146 & $66,7 \%$ \\
2003 & 707.430 & 1.118 .603 & $63,2 \%$ \\
2004 & 742.005 & 1.295 .800 & $57,3 \%$ \\
2005 & 757.235 & 1.369 .182 & $55,3 \%$ \\
\hline
\end{tabular}

(Fonte: Anuário da Indústria Automotiva Brasileira 2006) 
Mesmo em meados do ano de 2004, com a introdução dos modelos bicombustíveis, nos quais se permite utilizar álcool ou gasolina, ou ambos em qualquer proporção, não houve mudança neste cenário, uma vez que os populares também foram incluídos na gama de produtos oferecidos com esta nova tecnologia.

\subsection{Considerações Iniciais}

O cliente exige veículos mais robustos e que não apresentem falhas que o façam retornar a concessionária ou oficina autorizada para repará-los. Desta forma, a qualidade dos produtos está diretamente relacionada à satisfação dos clientes, que reconhecem a qualidade de veículo em três conceitos diferentes, aplicados em fases distintas no ciclo de vida de um veículo, segundo General Motors (2005):

Qualidade Percebida: É a qualidade que o consumidor percebe. É como o consumidor sente o produto como um todo, como a primeira impressão sobre aparência, toque, cheiro, etc. Itens como a sensação do tecido dos bancos do veículo e a disponibilidade de espaços para armazenar objetos. Estes são exemplos de detalhes que influenciam a percepção de qualidade pelo consumidor.

Qualidade Inicial: É a qualidade do veículo nos seus primeiros noventa dias de uso, quando o cliente experimenta o carro.

Durabilidade e Confiabilidade: Demonstra quanto o veículo é confiável no decorrer dos anos e após muitos quilômetros rodados. É a credibilidade do produto durante todo o período em que ele permanece com o consumidor.

As montadoras projetam os seus produtos baseados em uma expectativa de vida útil para os mesmos. Durante a fase de desenvolvimento do veículo, o fabricante normalmente prioriza as suas atividades em atingir as especificações de desempenho e objetivos de lançamento dentro do prazo e custos estipulados no início de projeto. Embora a maioria das empresas tenha consciência de que os fatores decisivos para o sucesso de um produto são o encontro do custo para o 
lançamento do veículo e a sua confiabilidade, é sabido que os problemas encontrados fora do período de garantia acabam por afetar a imagem da marca.

Por outro lado, os custos causados pela garantia não são desejados pela empresa e com o agravante de que haverá um cliente insatisfeito que acabará por levar o seu veículo a uma concessionária para que o mesmo seja reparado, gerando custos e danos a imagem da empresa como conseqüência.

Um importante desafio para as empresas fabricantes de veículos é oferecer um produto ao cliente que tenha um alto índice de confiabilidade. Este desafio específico para as empresas envolve projetar produtos com alta confiabilidade em tempos de desenvolvimento cada vez mais reduzidos, com rotineiras iniciativas de redução de custos e com a pressão de marketing para a geração de novos produtos com forte apelo visual.

Diante do mercado competitivo atual, as montadoras de veículos são obrigadas a conceber produtos para o cliente que atendam a voz do mesmo e apresentem simultaneamente alta confiabilidade. Embora não seja um requerimento explícito, o desejo e necessidade por veículos com alta confiabilidade são implícitos em muitos clientes.

Os fatores mais determinantes para a confiabilidade de um produto são as fases em que são atribuídas as especificações de produto e processo. Nestas fases, a confiabilidade pode ser projetada antes mesmo de esperar por resultados finais de testes ou dados de garantia. Normalmente as mudanças neste ponto são mais caras que feitas no momento do projeto do produto.

Nos últimos dez anos, as montadoras de veículos instaladas no território brasileiro melhoraram a qualidade de seus produtos em função do aumento do número de fabricantes instalados no Brasil e também diante da abertura de mercado para veículos importados. Algumas montadoras estenderam o período de garantia em alguns de seus produtos de um para três anos como estratégia de marketing e vantagem competitiva de mercado, como pode ser observado nos recentes exemplos de Chevrolet Vectra, Toyota Corolla e Honda Civic, todos 
reconhecidamente pertencentes ao nicho de mercado de veículos de luxo, em que os seus fabricantes primaram pela robustez e durabilidade durante as fases de projeto e desenvolvimento.

\subsection{Objetivo do Trabalho}

Desde 1990, na ocasião da abertura de mercado para importação de veículos, a indústria automotiva tem sido muito questionada a respeito de problemas de qualidade e como os custos de garantia de seus produtos são gerenciados. Por este motivo as montadoras estão cada vez mais aplicando ferramentas de qualidade nas fases iniciais de projeto dos novos produtos com o objetivo de prever com maior antecedência os problemas que não tenham sido identificados anteriormente. Eventuais atrasos na detecção de problemas podem acarretar em perdas financeiras para as empresas através do custo de garantia, que é um importante indicador de desempenho financeiro. Este indicador é apresentado de forma percentual (\%) sendo calculado da seguinte maneira:

$$
\%=\mathrm{VPR} / \mathrm{VRV}
$$

Onde:

$\%=$ Custo de garantia

VPR = Valor pago pela empresa para reparar veículos;

VRV = Valor recebido nas vendas destes veículos.

Segundo Murad (2005), quanto menor a quantidade de reparos realizados dentro do período de garantia, melhor será este indicador. Isto significa que a qualidade dos seus produtos pode influenciar de maneira positiva ou negativa nos resultados financeiros da empresa. Para os fabricantes fornecerem um determinado prazo de garantia, é necessário conhecer o comportamento e confiabilidade de seus produtos 
com o objetivo que os custos envolvidos com os reparos durante estes prazos oferecidos não tragam prejuízos.

Murad (2005) assinala que no passado muitas empresas tinham grandes margens de lucro ao vender peças de reposição para os seus produtos que apresentavam baixa confiabilidade. Porém, atualmente os veículos atuais são mais confiáveis e a confiabilidade tornou-se um ponto a ser considerado no momento da compra de um veículo e estender o seu período de garantia é somente mais uma forma de mostrar aos clientes a alta confiabilidade de seus produtos.

A habilidade da organização em identificar e reagir rapidamente a novos eventos de falha é primordial no atual cenário de alta competitividade, utilizando de todos os meios possíveis de extrair e integrar dados de todas as fontes possíveis, incluindo a construção de protótipos, utilização de campos de provas, análise dos dados de garantia, programas de ligações telefônicas e reclamações de clientes.

Um dado importante a ser considerado neste estudo é que conforme a Grupo Interprofissional Pesquisas Automóvel (Gipa), um veículo novo comprado nos concessionários das montadoras instaladas no Brasil, normalmente demora três anos na média para ser vendido ou colocado como moeda de troca na compra de um outro veículo.

Diante do cenário de alta competitividade que envolve o mercado automotivo atual e a alta influência das vendas dos veículos populares, como se comportaria um produto da categoria veículos populares quando submetido a um período maior de garantia? As peças que sofreriam falhas seriam as mesmas que sofrem falhas durante o período de um ano de garantia? Os modos de falha verificados para veículos expostos em três anos seriam diferentes dos modos de falhas verificados no primeiro ano de exposição do veículo?

Em função da grande participação dos veículos populares no mercado brasileiro, este trabalho tem como objetivo abordar a extensão do período de garantia nestes produtos como vantagem competitiva no mercado, utilizando a voz do cliente e as informações dos dados de garantia do produto atualmente comercializado pela 
empresa como entrada através do banco de dados de falhas de campo da assistência técnica da montadora. Com estes dados disponíveis, serão utilizados modelos de tomada de decisão para verificar a possibilidade quanto à extensão do período de garantia em veículos populares.

\subsection{Organização do Trabalho}

Este trabalho está organizado em sete capítulos, sendo este o primeiro, apresentando uma breve introdução do tema, assim como as considerações iniciais, objetivo e a organização do trabalho.

O segundo capítulo traz os fundamentos teóricos, baseados nas referências bibliográficas quanto a aspectos gerais sobre o tema da garantia, assim como alguns conceitos de confiabilidade e definições de falhas.

Os fundamentos teóricos dos bancos de dados de falhas de campo são explorados no terceiro capítulo, que também contém uma breve descrição do banco de dados de falhas da empresa.

O quarto capítulo traz o método para cálculo do custo de garantia para veículos populares após 36 meses de exposição no campo, com o detalhamento do custo de garantia no preço final do veículo e o modelo para definição do custo de garantia em 24 e 36 meses de exposição no campo, complementado por uma análise crítica do método proposto.

A proposta de implementação da extensão do período de garantia é descrito no quinto capítulo, com uma análise crítica quanto à viabilidade técnica e financeira, com foco na exeqüibilidade das propostas quanto ao tempo de execução.

O sexto capítulo traz as conclusões e considerações finais, o que permite verificar que a extensão do período de garantia para veículos populares será de grande 
benefício para a empresa, caso esta esteja disposta a assumir os riscos descritos nos capítulos anteriores.

As referências bibliográficas consultadas para o referencial teórico deste trabalho estão descritas no sétimo capítulo. 


\section{FUNDAMENTOS TEÓRICOS}

\subsection{A Origem e História da Garantia}

O conceito de garantia remonta ao início da humanidade, mais precisamente com o início da atividade do comércio, a partir da qual surgiram questões relacionadas à qualidade dos produtos e serviços ofertados. O Código de Hamurabi, conjunto de leis datado do século XX a.C., já abordava o tema, visando regular as relações comerciais e proteger os direitos de compradores e vendedores, assim como diversas outras civilizações posteriores o fizeram, como os hindus, islâmicos, romanos, germânicos, judeus, ingleses e russos (Loomba, 1998 apud Figueiredo, 2005).

Durante a Idade Média, a garantia legal foi codificada por São Tomás e Aquino, com o objetivo de proteger os compradores nas relações comerciais, sistema conhecido como coveat venditor, ou "o vendedor que se acautele". Já a partir do século XVI, a situação se inverteu, tendo o comprador que se acautelar em transações que pudessem lhe trazer prejuízo, o chamado sistema caveat emptor (Hart, 1996, Loomba, 1998 apud Figueiredo, 2005).

Esta situação permaneceu inalterada até a segunda metade do século XIX, quando houve a primeira grande transformação em termos de uso de garantias. As garantias contratuais começaram a ser utilizadas como ferramentas promocionais pelas empresas americanas, se sobressaindo às fracas garantias legais existentes. Isto ocorreu em virtude de um aumento considerável da escala de produção destas companhias e de sua conseqüente busca de aumento de participação no mercado, pois até então atendiam somente a comunidades locais, e a propaganda boca-aboca era a única forma de se determinar a qualidade do produto ou serviço ofertado, sendo necessário formalizar a garantia para conquistar clientes por todo o país (Hart, 1996, Loomba, 1998 apud Figueiredo, 2005). 
Diversos tipos de garantias foram oferecidos aos consumidores, gerando resultados positivos para as companhias. A partir disto, inúmeras empresas entraram no mercado ofertando garantias para aumentarem as suas vendas. Porém, as garantias não eram cumpridas, o que prejudicou sua imagem nos EUA, até a regulamentação desta prática comercial nas décadas de 30 e 40, eliminando as garantias contratuais fracas, pois já estavam cobertas pelas novas garantias legais. Desta forma, apenas as garantias poderosas se mantiveram, funcionando como excelentes ferramentas de marketing para as empresas (Hart, 1996, Loomba, 1998 apud Figueiredo, 2005).

Finalmente, a segunda grande transformação nos termos de garantia ocorreu na década de 60, quando foi verificada a ligação da garantia com a qualidade. Isto ocorreu por surgimento de um elo fraco entre a oferta de uma garantia e a satisfação do cliente. Na verdade, foi o setor de serviços que adotou a ferramenta com maior intensidade na década de 80 , ao reconhecer o diferencial qualitativo através do qual as garantias podem ser utilizadas a favor de significativas vantagens (Hart 1996 apud Figueiredo, 2005).

\subsection{Definição Jurídica de Garantia}

Abordar a garantia de um produto atualmente, representa muito mais do que garantir a qualidade de um artefato ou de política de fidelização do cliente. Trata-se de assegurar e respeitar os direitos do consumidor, respeitando a legislação vigente no Brasil.

No Brasil, a partir de 1988 com a entrada em vigor da Constituição Federal, já havia uma preocupação em assegurar os direitos do consumidor, o que culminou na criação do Código de Proteção e Defesa do Consumidor em 1990, através da Lei noㅡ 8078/90, a qual trouxe em seu bojo diversos itens relacionados diretamente com a garantia, na qualidade, segurança, durabilidade e desempenho de produtos e serviços em geral 
Assim, com a vigência do Código de Proteção e Defesa do Consumidor, os fabricantes e prestadores de serviços passaram a observar seus produtos de maneira a se adequarem ao cumprimento da lei.

Primeiramente, a Lei 8078/90 definiu a pessoa do consumidor como sendo toda pessoa física ou jurídica que adquira ou utilize produto ou serviço como destinatário final. Definiu também como política governamental a garantia dos produtos e serviços com padrões adequados de qualidade, segurança, durabilidade e desempenho.

Desta maneira, a garantia deixou de ser um diferencial na hora da escolha de um veículo para se tornar um item exigido por lei. Tal é a seriedade da abordagem da garantia para fins de assegurar os direitos do consumidor que o Código traz um artigo somente para tratar do assunto, fazendo com o que a garantia deixe de ser uma "benesse" do fabricante para ser um direito do consumidor.

O artigo 26 da Lei elenca o prazo de garantia de um produto durável, aderindo ao prazo concedido pelo produtor, ou seja, é adicionado ao final do prazo contratual. Para o Código, noventa dias é o prazo mínimo que um produto durável deve manterse em perfeito estado de qualidade, segurança e desempenho.

A segurança e desempenho de produtos e serviços é tão importante hoje em dia, que se não observados os critérios legais, responde o fabricante ou produtor, independentemente de culpa, pelos danos causados ao consumidor ao utilizar produtos e serviços.

Assim, deixar de observar a garantia de um produto hoje em dia, é desvalorizar políticas de consumo e o próprio consumidor, arriscando-se a responder judicialmente pelos problemas e defeitos oriundos dos produtos colocados em circulação. 


\subsection{Definição Técnica de Garantia}

A palavra "garantia" em sua acepção no campo das relações comerciais pode ser definida como "compromisso que o vendedor assume de entregar ao comprador a mercadoria sem defeitos" (Michaelis, 2000).

Neste contexto específico de negócios, Adams (1982) apud Figueiredo (2005) define a garantia como uma promessa ou afirmação pelo vendedor com relação à qualidade dos produtos/serviços ou sua adequação para uso específico. Sem garantia, os produtos/serviços são vendidos na condição de o vendedor não possuir responsabilidade por quaisquer falhas ou imperfeições nos produtos/serviços, e de o comprador não possuir o direito de devolvê-los ou cobrar qualquer reparação pelos danos causados.

Quanto aos tipos de garantias, estes são apresentados na Figura 1 a seguir, elaborada com base nas definições de Hart (1998) apud Figueiredo (2005).

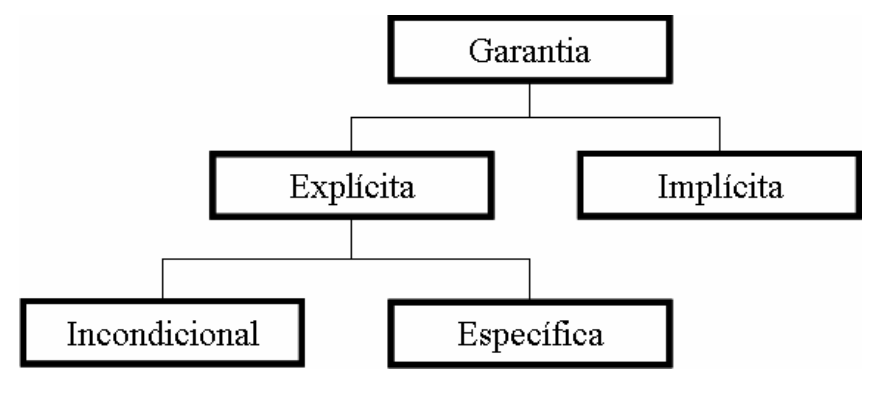

Figura 1 - Tipos de Garantias (Hart, 1996, apud Figueiredo 2005)

\subsubsection{Garantia Explícita}

A garantia explícita pode ser subdividida em dois tipos: A incondicional e a específica. A principal diferença entre ambas está relacionada à cobertura que terão sobre os produtos e serviços. 


\subsubsection{Garantia Incondicional}

A garantia incondicional define a satisfação do cliente como sua missão, sendo a mais ampla de todas as garantias em termos de cobertura, e assim considerada por diversos autores como a garantia mais forte existente (Hart 1996, apud Figueiredo 2005).

Apesar de sua força, a garantia incondicional é mais fácil de ser estabelecida e seu efeito potencial sobre a qualidade é bem maior, pois qualquer falha da companhia, seja em momentos de verdade cruciais ou em fatores sutis, irá levar o cliente a reclamar, possibilitando identificar e corrigir estas falhas, além de compensar o cliente e evitar a sua perda (Hart 1996, apud Figueiredo 2005).

Entretanto, há desvantagens na adoção de uma garantia incondicional de satisfação para uma companhia, como um número bastante elevado de exigências e compensações, muitas vezes por motivos banais e até mesmo fora do controle da companhia, além de reclamações legítimas de clientes que desejam tirar proveito da garantia. Tudo isso acarreta inevitavelmente em casos de garantias que são pagas sob condições excessivas (Hart 1998, apud Figueiredo 2005).

\subsubsection{Garantia Específica}

A garantia específica, também chamada de garantia de desempenho, permite que a empresa defina exatamente quais atributos do produto/serviço deseja incluir em sua cobertura. Assim, a companhia não se sente obrigada a compensar o cliente por falhas que não estejam diretamente relacionadas aos seus produtos, seja qual for o nível de insatisfação do cliente (Hart 1996, apud Figueiredo 2005).

Embora possua uma cobertura menor que a garantia incondicional de satisfação, a garantia específica é também poderosa, pois além de limitar reclamações não razoáveis, foca a atenção do cliente no atributo do produto/serviço que a companhia 
deseja manter em destaque, seja por traduzir o que é mais importante para o cliente, ou pela vantagem competitiva da empresa naquele tributo específico (Hart 1996, apud Figueiredo 2005).

Muitas vezes as empresas não se sentem confortáveis em ofertar uma garantia específica por diversos motivos, como processos sem controle de qualidade, clientes desonestos, falta de habilidade em fornecer explicações ao cliente ou critérios específicos de desempenho influenciados por fatores incontroláveis. Existe a possibilidade de limitar ainda mais o alcance das garantias, mas com isto elas terão menor efeito sobre os clientes e sobre a melhoria da organização. Algumas alternativas possíveis por (Hart 1996, apud Figueiredo 2005):

- Solicitar ao cliente que atenda a determinadas condições, permitindo à empresa oferecer uma garantia normalmente impossível em determinados produtos/serviços;

- Limitar a compensação para cada acionamento da garantia, especialmente nos casos em que o cliente estará satisfeito com uma compensação parcial, como um dos atributos de produto/serviço do qual ele não espera alto desempenho;

- Repor o produto/serviço, ao invés de compensar com recursos financeiros, pois além de ter um custo menor para a empresa, evita que o cliente migre para a concorrência, fazendo com que o mesmo permita uma segunda chance para a companhia. É evidente que há uma possível desvantagem no caso de o cliente se sentir obrigado a usar o mesmo produto/serviço após uma experiência mal sucedida e com isto a garantia perderá a sua força.

A empresa pode ainda trabalhar de forma criativa nas compensações que irá oferecer aos seus clientes. Uma delas é garantir a satisfação dos clientes dos seus clientes, pois este é o interesse dos últimos, transferindo a garantia para os primeiros. Outra possibilidade reside na opção de o cliente escolher, dentre diversas compensações apresentadas pela companhia, àquela que mais lhe interessa (Hart 1996, apud Figueiredo 2005). 
Com relação às garantias contratuais não cobertas pelo Código, já se verifica uma oferta pelas empresas brasileiras, mas ainda não se conhece o seu objetivo, se utilizada apenas como uma ferramenta de marketing ou como uma ferramenta de gestão e melhoria de qualidade.

Segundo Berke \& Zaino (1991), existem os seguintes tipos de garantia:

- Garantia de Substituição Livre: O fabricante paga o custo inteiro de reparo ou substituição se o produto falhar antes de encerrar o prazo de garantia. Esta política de garantia pode ser dividida em:

- Política de Substituição Livre Ordinária: Nesta política o item substituído ou reparado possui garantia igual ao tempo restante da garantia original;

- Política de Substituição Livre Ilimitada: Nesta política a substituição do item leva a uma garantia idêntica à garantia original registrada durante a compra;

- Política Pró-Rata: Nesta política, o custo de substituição ou reparo de um produto para o comprador, depende da idade do produto quando a falha ocorreu. No início desta garantia os custos a serem pagos pelo cliente são nulos e no final ( $\mathrm{t}$ ) o custo é todo pago pelo cliente. Entre este intervalo $\left(\mathrm{t}_{\mathrm{i}}\right)$, os custos são ponderados, uma quantia é desembolsada pelo cliente e outra pelo fabricante. A Figura 2 mostra como funciona este tipo de garantia. 


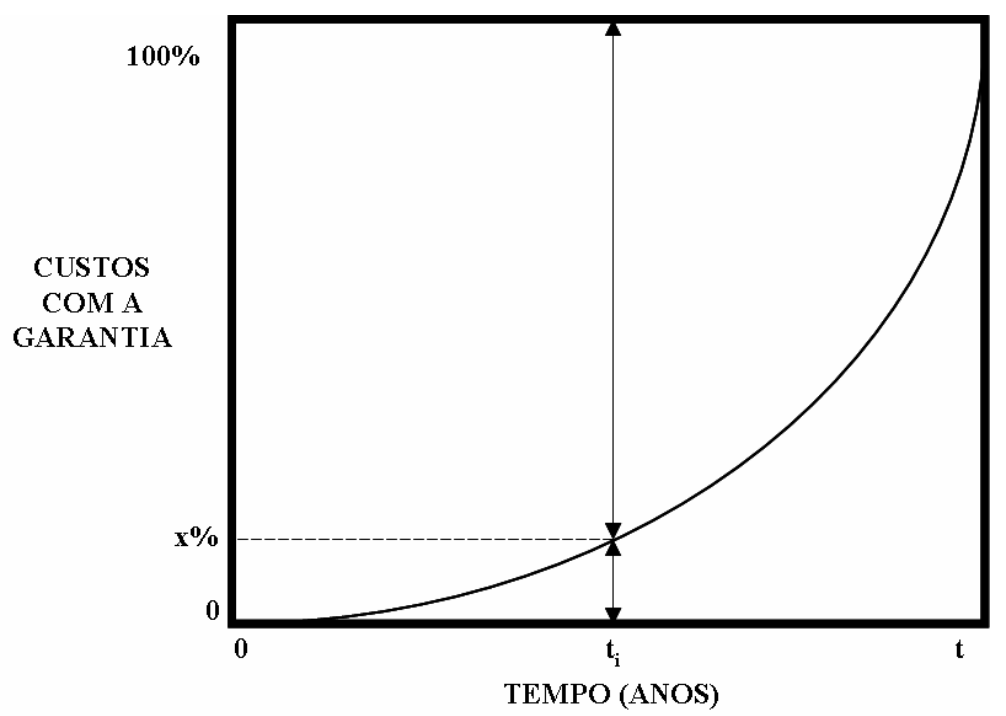

A forma da curva $f(x)$ é uma questão que deve ser pesquisada de forma que satisfaça tanto o cliente como o fabricante.

- Política Combinada: Esta política combina a garantia de substituição livre com a política pró-rata. É evidente que para o comprador é melhor a política de garantia de livre substituição enquanto que para o fabricante é melhor a política pro-rata. Assim uma política que envolva um período inicial de substituição livre seguido por um período pró-rata é um compromisso razoável tanto para o fabricante quanto para o usuário. A Figura 3 mostra como poderia ser esta política combinada.

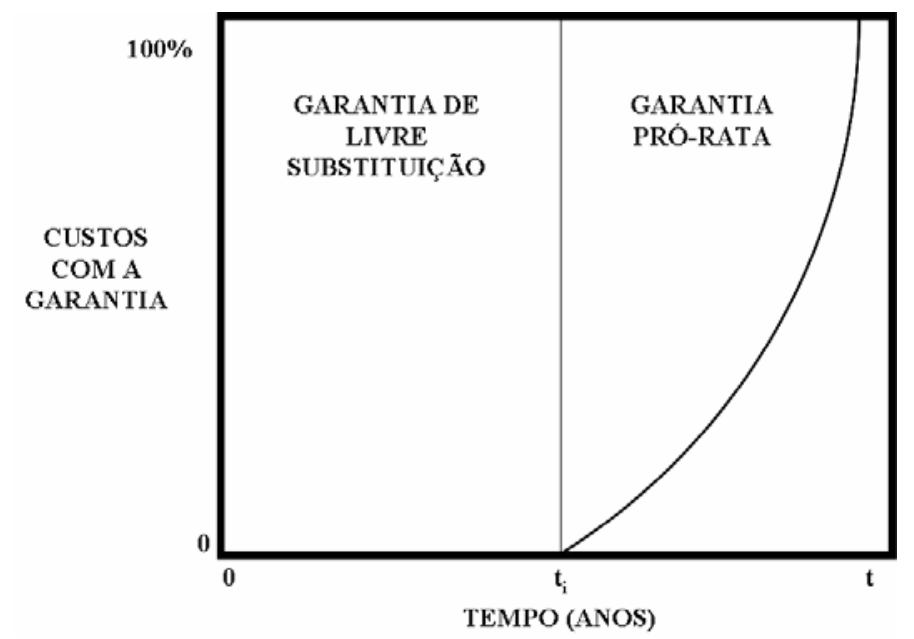

Figura 3 - Política de Garantia Combinada (Berke \& Zaino, 1991) 
A Figura 3 mostra que até o tempo $t_{i}$, o cliente possui uma garantia de livre substituição, ou seja, os custos envolvidos com os reparos são totalmente cobertos pelo fabricante. Após este tempo, os custos são então rateados entre cliente e fabricante.

Tradicionalmente, uma garantia fornece uma restituição em termos de substituição ou reparo livre de gastos para o cliente se o produto não atender às especificações. Segundo Berke \& Zaino (1991), o valor ou a importância de uma garantia depende fortemente do ponto de vista que ela é vista. Os clientes necessitam de garantias para assegurar que o fabricante assuma a responsabilidade do seu produto por um período de tempo especificado. Porém esta especificação não é inteiramente livre para o cliente, visto que o fabricante espera certo número de reclamações dentro do período de garantia e inclui os custos decorrentes destas reclamações dentro do preço do produto.

O prazo de garantia depende totalmente da confiabilidade de um produto, ou seja, se o produto é confiável, um prazo maior de garantia pode ser oferecido. Caso contrário, o fabricante sofrerá com os altos custos com reparos dentro deste período ao mesmo tempo em que grandes períodos de garantia servem como indicadores da confiabilidade de um produto e podem aumentar as vendas. O período de garantia pode ser influenciado pela competição no mercado consumidor.

Atualmente com os produtos comerciais, a competição do mercado está levando a uma concorrência para o aumento dos prazos de garantia, mas quase todos com uma política de substituição livre ordinária.

Alguns tipos de garantias contratuais também não estão relacionados ao objetivo do trabalho, visto que não partem de iniciativa própria da companhia ou quando o cliente é penalizado financeiramente. Estes tipos de garantia e os motivos para exclusão são (Hart 1996, apud Figueiredo 2005);

- Garantias contratuais pelas quais o cliente explicitamente paga a mais: Quando a garantia é oferecida através de uma cobrança adicional, como uma 
espécie de proteção extra ao cliente, este desconfia que a empresa esteja buscando apenas lucrar mais no relacionamento entre ambos;

- Garantias contratuais impostas a uma empresa por um cliente (penalidades por ausência ou falha de desempenho): Uma empresa forçada a alcançar certo nível de desempenho por causa de um contrato, por exemplo, aos requisitos exigidos, com um mínimo de esforço adicional;

- Garantias contratuais oferecidas por terceiros: mesmo que possam ser ou não valiosas para os clientes, têm pouca influência na maneira através da qual a empresa fornecedora do produto/serviço gerencia os seus negócios.

Os fabricantes especificam as garantias dos seus produtos para que as falhas ocorram somente após o final das mesmas. Os fabricantes normalmente utilizam peças e configurações que possuem um período de vida útil limitado. Quando este limite é atingido, os produtos começam a falhar em grande número. Isto gera ao fabricante um mercado repetitivo, assumindo que os clientes retornarão para comprar o mesmo produto ou similar do mesmo fabricante, preterindo assim o produto da concorrência (Robinson \& Okogbaa, 1999).

Segundo Kotler (2000), todas as empresas vendedoras são legalmente responsáveis pela satisfação das expectativas normais ou razoáveis dos compradores. Garantias de funcionamento são declarações feitas pelo fabricante relacionadas ao desempenho do produto. Produtos que estejam na garantia podem ser devolvidos ao fabricante ou encaminhados a uma assistência técnica para que sejam consertados ou trocados ou para que o comprador seja reembolsado. Garantias de funcionamento, tanto as expressas claramente, quanto as implícitas, são legalmente obrigatórias.

Muitas empresas vendedoras oferecem garantias de reposição, que são garantias que o produto pode ser devolvido caso seu desempenho seja insatisfatório. O cliente deve ter acesso a garantias claramente declaradas e fáceis de serem executadas, e a empresa deve promover a reparação com rapidez. Caso contrário os clientes ficarão insatisfeitos, falarão mal da empresa e terão em mãos o necessário para um processo na justiça (Kotler, 2000). 
As garantias são mais eficazes em duas situações. A primeira é quando a empresa ou o produto não é conhecido. Uma garantia de devolução do dinheiro caso o cliente não fique satisfeito proporciona aos clientes certa confiança na compra do produto. $A$ segunda situação é quando a qualidade do produto é superior a da concorrência. A empresa pode ganhar ao garantir um desempenho superior estando ciente de que os concorrentes não conseguem oferecer o mesmo tipo de garantia (Kotler, 2000).

O cliente quando adquire um produto está aceitando que este poderá falhar em algum instante no futuro. Este enfoque é frequentemente acoplado com uma garantia, que pode estar em lei ou não, de forma que ele possa reivindicar de falhas que possam ocorrer dentro de um período especificado (O'Connor, 1988).

\subsection{Benefícios da Garantia}

De acordo com diversos autores, a garantia é uma ferramenta que pode desempenhar papel fundamental para que o processo de gestão e melhoria da qualidade seja efetivamente implementado no longo prazo, além do seu poder como ferramenta de marketing, gerando efeitos de curto prazo nas vendas da companhia (Hart 1996, apud Figueiredo 2005).

Observando estas informações e o histórico referente a garantias, é possível inferir os dois principais motivos que estimulam as empresas a adotarem uma garantia: Utilizarem como uma ferramenta de marketing e/ou gestão da melhoria da qualidade para melhoria da imagem.

\subsubsection{A Garantia como Ferramenta de Marketing}

A principal função da garantia como ferramenta de marketing para as empresas consiste em reduzir a percepção de risco que o cliente tem na ocasião da compra, 
além de sinalizar para este uma melhor qualidade, diferenciar seu produto/serviço da concorrência e aumentar sua intenção de compra (Hart 1996, apud Figueiredo 2005).

Desta forma o cliente será motivado a comprar primeiramente por acreditar que a empresa não irá falhar com o compromisso, além do fato de estar seguro de que se houver uma falha ele não terá prejuízo. Além disso a principal diferença entre a garantia e outras ferramentas de marketing está no fato de que a primeira é um contrato legal que se voltará contra aqueles que a oferecem (Hart 1996, apud Figueiredo 2005).

A garantia também serve como uma forma de recuperação de serviço, ao estimular a reclamação por parte dos clientes com uma compensação (Hart 1996, apud Figueiredo 2005).

Isto ocorre porque considera que o custo de manter um cliente é bem mais baixo que conquistar um novo cliente, e sabendo que aqueles que reclamam são normalmente os clientes mais conscientes, leais e dispostos a falar com outras pessoas sobre o serviço que Ihe foi prestado, a maneira como a empresa atende a estas reclamações tem impacto direto sobre a lealdade dos clientes (Hart 1996, apud Figueiredo 2005).

\subsubsection{A Garantia como Ferramenta da Gestão e Melhoria da Qualidade}

Devido à velocidade de avanço da tecnologia e a influência dos clientes, as empresas tem que ser capazes de oferecer aos clientes produtos com maior qualidade e com menor custo. Entretanto, o fenômeno da globalização acelerou a mudança de perfil de consumo dos clientes. Atualmente, as atrações de um produto dependem não somente de condições tangíveis como preço, funcionabilidade, promoções e estética, mas também de aspectos intangíveis como reputação da empresa, lealdade à marca, experiências de compras anteriores, e serviço ao cliente, etc. (Huang \& Zuo, 2004). 
Entretanto, em um mercado competitivo, as características físicas de um produto não são usualmente os fatores primários entre a escolha entre vários produtos similares. Ao contrário, o serviço de pós-vendas e a manutenção exercem papéis fundamentais não somente em salvaguardar os direitos e interesses dos clientes, mas também por promover aos vendas e a reputação das empresas. Em particular, uma boa política de garantia de serviço e manutenção ajuda a promover a imagem de produtos de alta qualidade e pode tornar-se uma importante arma para o marketing de produtos em mercado altamente competitivo. Entretanto, uma garantia ilimitada para monopolizar o mercado é totalmente irreal, baseado no fato que os custos seriam altos para manter uma política de garantia com tais características (Huang \& Zuo, 2004).

Porém, não é apenas como ferramenta de marketing, como a maioria das empresas pensa, que a garantia gera resultados positivos. A garantia também deve ser adotada sob a perspectiva das operações, considerando sua influência na gestão e melhoria da qualidade de uma companhia. Isto é quase sempre percebido apenas quando a ferramenta já foi implementada (Wirtz 1998, apud Figueiredo 2005).

$\mathrm{Na}$ verdade, se uma empresa não considerar a interdependência entre marketing e operações no momento de ofertar uma garantia, ela pode acabar gerando promessas tão cedo que só depois irá perceber que suas limitações operacionais não permitem atender às promessas já feitas, tendo às vezes que retirar a garantia do mercado para não ir à falência e prejudicando a sua credibilidade (Chatterjee, et al, 2003).

Em casos em que a companhia possui operações deficientes é realmente mais complicado implementar a garantia devido aos custos que seriam incorridos. Este aumento de custos vai depender basicamente dos seguintes aspectos: fraqueza da companhia em desempenho, natureza do setor, e o poder de competição da companhia (Hart 1998, apud Figueiredo 2005).

Por outro lado não se pode deixar de observar os benefícios incorridos na adoção desta ferramenta gerencial em termos de melhoria de qualidade, envolvendo fatores como menor índice de falhas, maior produtividade e maior freqüência de negócios, 
superando de longe todos os custos anteriormente citados (Hart1998, apud Figueiredo 2005).

Hart apud Figueiredo (2005) destaca como principais benefícios para uma empresa que implementa uma garantia, além da força que gera em termos de marketing, os seguintes aspectos relacionados à gestão e melhoria da qualidade:

- Uma garantia força o foco da empresa no cliente: Uma garantia precisa ter sentido para o cliente, ou seja, representar algo que agregue valor a este. Se a empresa não reconhece as necessidades do seu cliente, pode acabar fornecendo garantias sobre atributos do seu produto/serviço que não são importantes para o seu público alvo;

- Uma garantia define padrões claros: Através da adoção de uma garantia, a empresa precisa definir padrões operacionais claros para que aquela promessa seja atendida. Isto força a empresa a definir o papel e a responsabilidade de cada funcionário na entrega do seu produto/serviço. Além disso, a implantação de um mecanismo de compensação financeira gera prejuízos para a organização quando ocorrem erros na entrega do produto, obrigando à gerência a estar atenta com relação à satisfação dos seus clientes, o que faz com que a ferramenta seja levada a sério por todos na empresa;

- Uma garantia gera retroalimentação: Ao fornecer garantias que incentivem o cliente a reclamar, a empresa encontra uma maneira de identificar falhas não verificadas anteriormente, possibilitando a sua correção e gerando um processo de aprendizado para a organização;

- Uma garantia força a empresa a entender porque falhou: Ao desenvolver uma garantia, é necessário compreender o sistema de entrega dos produtos/serviços da organização, com o objetivo de identificar possíveis falhas no processo. Para isto é fundamental conhecer bem aspectos operacionais básicos na operação, como o tempo de processo, a capacidade e o fluxo do mesmo. Deve-se considerar também a capacitação dos funcionários envolvidos, através da contratação e treinamento adequados para as funções especificadas no processo que esteja alinhado com a garantia estabelecida. 
Observando os benefícios apresentados, verifica-se que somente os dois primeiros estão relacionados ao projeto do produto/serviço, enquanto os dois últimos envolvem o gerenciamento de falhas e de pessoal.

Wirtz apud Figueiredo (2005) reuniu os benefícios de uma garantia apresentados anteriormente em modelo para o setor de serviços, modelo este adaptado para a garantia para produtos e apresentado na Figura 4 na página seguinte.

De acordo com a figura, os principais benefícios de uma garantia são reunidos em três grupos: operações e qualidade, comportamento do cliente e desempenho do negócio.

No caso das operações e qualidade, primeiramente a garantia atua no projeto do produto/serviço, ao exigir o foco da empresa nas necessidades do cliente e estimular a compreensão e melhoria dos processos. No que se refere às falhas do produto/serviço e ao gerenciamento da recuperação, a empresa é forçada a entender e reduzir os pontos de falha, além de encorajar tanto a buscar retroalimentação do cliente como a formalizar a recuperação do serviço. E no quesito gerenciamento de pessoal, a empresa é estimulada a contratar e treinar funcionários de acordo com os padrões garantidos, assim como tornar estes mesmos padrões bastante claros para os funcionários. 


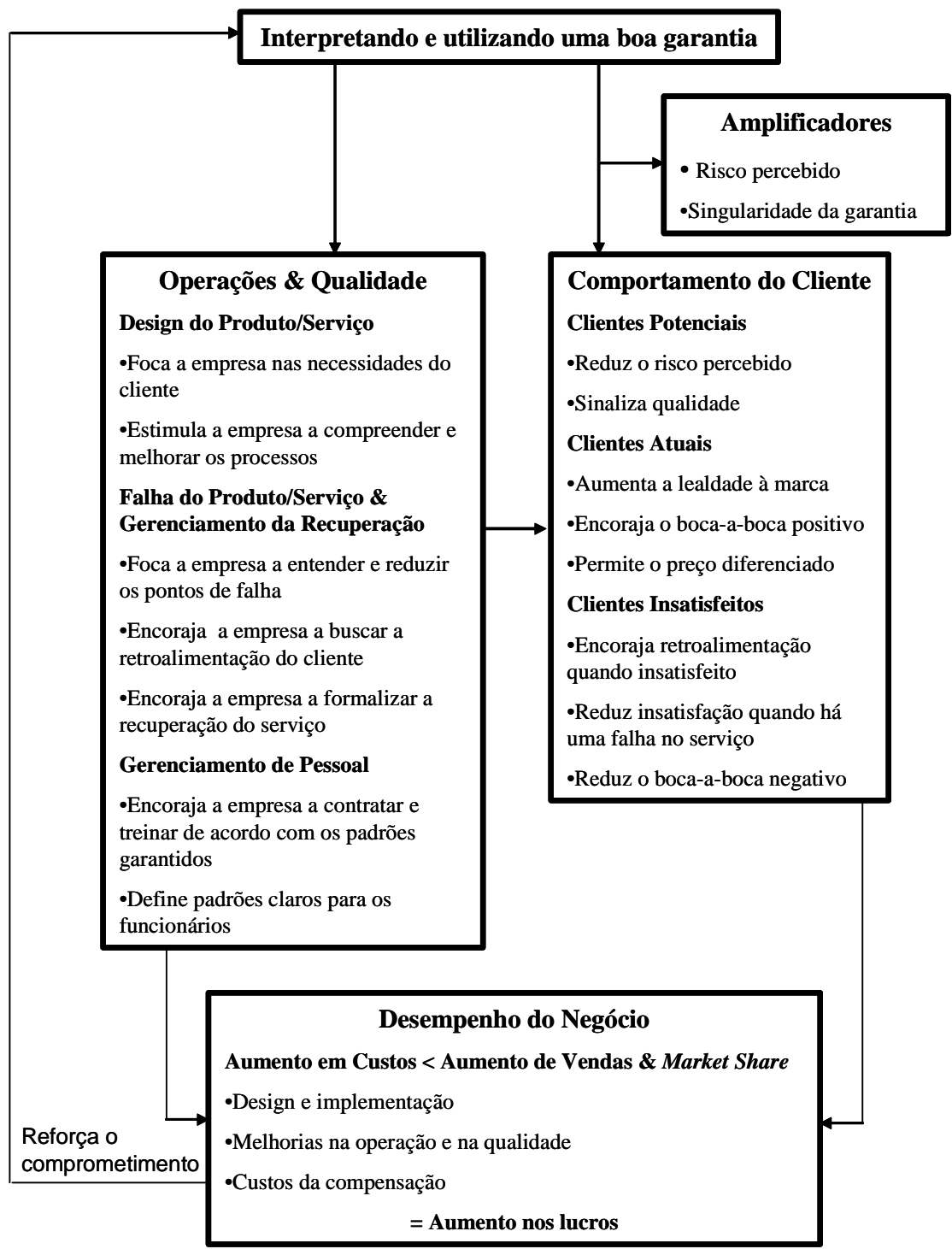

Figura 4 - Benefícios de Uma Boa Garantia (Wirtz, 1998, apud Figueiredo, 2005)

Em termos de impacto no comportamento do consumidor, a garantia atua em três segmentos. Os clientes potenciais são influenciados pela redução da percepção do risco e pela qualidade do produto traduzida através da garantia oferecida. Já os clientes atuais tornam-se mais leais à marca, gerando um boca-a-boca positivo para a empresa e permitindo adotar um preço diferenciado para seus produtos/serviços. Mas no caso dos clientes insatisfeitos, a garantia encoraja a retroalimentação por parte deles, possibilitando reduzir sua insatisfação quando houver uma falha, e gerando uma conseqüente redução do boca-a-boca negativo. 
Ainda como amplificadores do comportamento do cliente estão algumas características do setor que a empresa atua, sendo atribuído a elas o risco percebido pelo cliente quando da aquisição desta categoria de produto/serviço e a singularidade da garantia ofertada pela empresa em relação aos concorrentes do mercado.

Assim, o desempenho do negócio é afetado por todas estas variáveis. Mesmo com um aumento nos custos, referentes ao design e implementação da garantia, melhorias na qualidade e nas operações e compensações, o aumento em vendas e market share compensa, causando aumento nos lucros da empresa.

\subsection{Desenvolvimento e Implementação de uma Garantia}

O processo de desenvolvimento e implementação de uma garantia será apresentado em diversos passos a seguir (Hart 1996, apud Figueiredo 2005):

- Decidindo a adoção da garantia: Antes de iniciar o desenvolvimento de uma garantia é necessário questionar a adequação da ferramenta aos objetivos da empresa, tendo em vista o compromisso que se assume ao tomar a decisão de implementar a garantia;

- Definindo aspectos fundamentais no processo de desenvolvimento e implementação da garantia: Após a decisão pela implementação da garantia, é necessário definir alguns questionamentos importantes no que se refere ao processo de desenvolvimento e implementação da garantia dentro da empresa, com o comprometimento da alta administração com a garantia, um esforço de equipe no desenvolvimento da garantia e o fornecimento de informações pelos clientes.

Visando compreender o processo de desenvolvimento e implementação de uma garantia, Kandampully e Butler apud Figueiredo (2005) elaboraram um fluxo do mecanismo estratégico de desenvolvimento e implementação de garantias em serviço, adaptado para a garantia em produtos e apresentado na Figura 5 a seguir. 


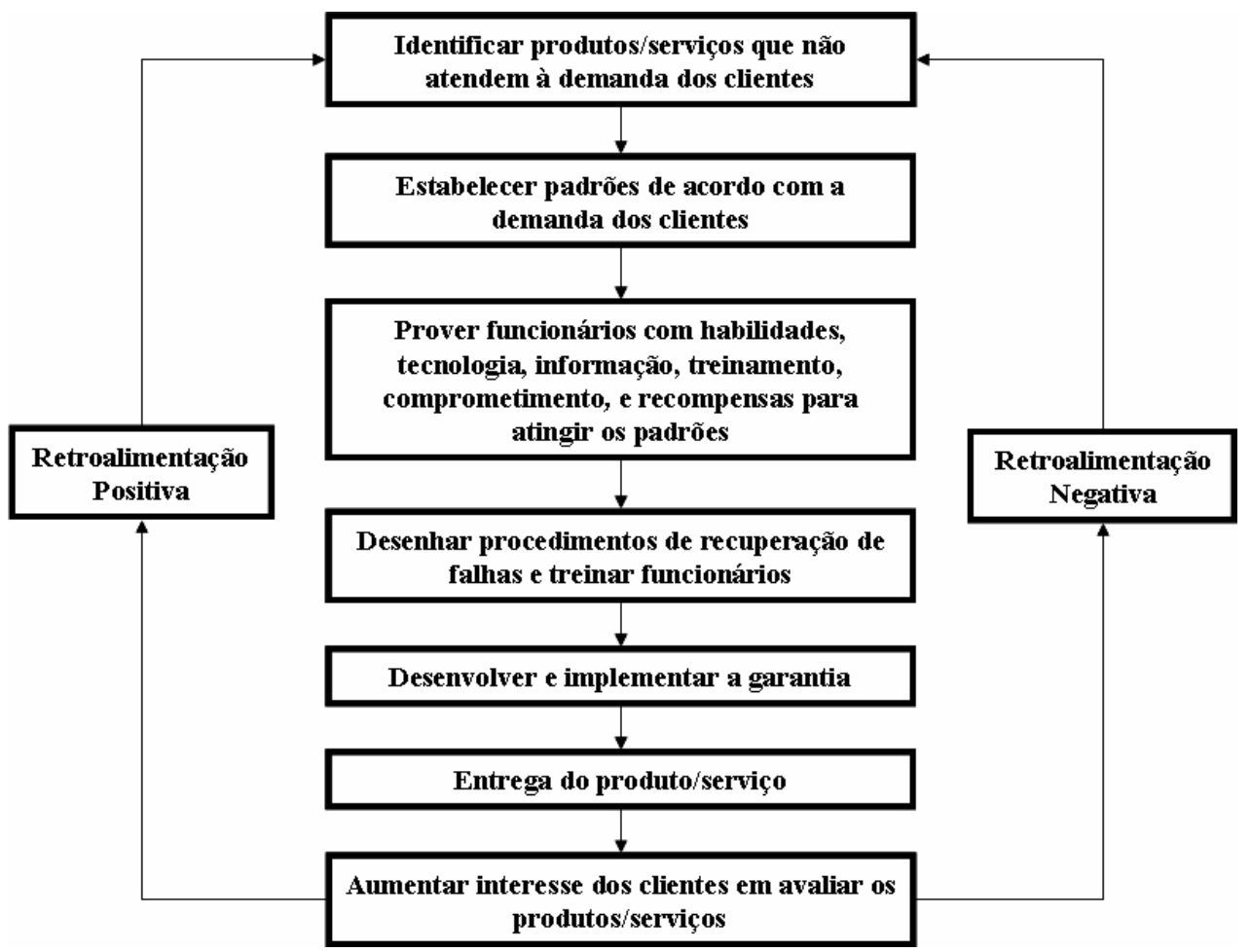

Figura 5 - Fluxo de Desenvolvimento e Implementação de Garantias (Butler e Kandampully, 2001, apud Figueiredo, 2005)

De acordo com a figura acima, o principal objetivo da companhia deve ser a promoção de retroalimentação tanto positiva como negativa por parte dos clientes, permitindo identificar os produtos/serviços que atendem às expectativas dos clientes e aqueles que não atendem. A partir daí, a companhia é capaz de avaliar a sua oferta atual e estabelecer novos padrões de acordo com a demanda dos clientes (Kandampully e Butler 2001, apud Figueiredo 2005).

Quanto mais cedo a empresa realizar esta etapa antes da implementação da garantia, melhor. Esta atitude evitará prejuízos iminentes para a empresa em termos de compensações extras e clientes desacreditados pela promessa de alta qualidade de garantia, além de dissipar qualquer ceticismo dos funcionários com relação ao comprometimento da empresa com a qualidade e consequentemente com a satisfação dos seus clientes (Hart 1996, apud Figueiredo 2005). 
A etapa seguinte consiste em fornecer aos gerentes e funcionários as habilidades, tecnologia, informação, treinamento, comprometimento, motivação e recompensas para alcançar estes padrões (Kandampully e Butler 2001, apud Figueiredo 2005).

Em termos de prover os funcionários com todos estes requisitos, é comum haver falhas na implementação de programas de qualidade quando estes vão descendo da alta administração para os níveis mais baixos da organização, quando os primeiros tentam impor motivação aos últimos. Portanto, antes de implementar a garantia, a empresa deve tentar cultivar nos funcionários atitudes apropriadas e comprometimento com a satisfação do cliente. Em adição, é necessário realizar uma comunicação extensiva do programa de garantia, estimulando a participação dos funcionários através de suas idéias e sugestões, utilizando aquelas que sejam mais apropriadas (Hart 1996, apud Figueiredo 2005).

Uma garantia também não terá êxito se o funcionário da linha de frente não possuir a autonomia e as ferramentas necessárias para tomar decisões que atendam à satisfação do cliente, pois eles serão os primeiros a identificar os problemas, sendo mais fácil solucioná-los. Entretanto, é necessário haver um ambiente em que os funcionários não sejam culpados pelas falhas, e sim que tenham a noção de recompensa de reparar um erro, pois a idéia da garantia não é de punir aqueles que falharam, e sim detectar problemas para correção dos processos (Hart apud Figueiredo 2005).

Estimular os funcionários financeiramente, de acordo com os ganhos que a empresa conquiste com a garantia, é um aspecto importante a ser destacado. Porém o foco da recompensa deve ser no recebimento e resolução de reclamações dos clientes, e não na redução das reclamações, o que poderia levar os funcionários a se sentirem desencorajados ou mesmo ignorar reclamações (Hart 1996, apud Figueiredo 2005).

O próximo passo é fundamental para a companhia, desenhar os procedimentos de recuperação de falhas no caso de não atender às expectativas dos clientes, treinando os funcionários e visando sua adequação a estes procedimentos (Kandampully e Butler 2001, apud Figueiredo 2005). 
A etapa de elaboração de procedimentos de recuperação de falhas é fundamental antes da oferta da garantia, a fim de se permitir que o fluxo de fornecimento de informações funcione de forma eficaz quando da implementação da ferramenta de gestão, fechando o ciclo do sistema de melhoria contínua da qualidade na organização (Hart 1996, apud Figueiredo 2005).

Em seguida vem o processo de desenvolvimento da garantia, permitindo não só à empresa desenvolver seus procedimentos internos, como também reforçar a confiabilidade dos seus produtos/serviços junto aos clientes. Estas ações se tornarão como a vantagem competitiva da empresa: Aumentar as intenções dos clientes em avaliar os produtos/serviços da empresa, além de gerar clientes mais leais (Kandampully e Butler 2001, apud Figueiredo 2005).

As etapas do desenvolvimento da garantia são as seguintes (Hart 1996, apud Figueiredo 2005):

- Escolhendo o tipo da garantia: Em primeiro lugar, é necessário decidir se será adotada uma garantia explícita ou implícita. Se houver a escolha da garantia explícita, é necessário definir também qual das suas opções será a mais indicada, a incondicional ou a específica;

- Definindo a compensação da garantia: A etapa seguinte consiste na escolha da melhor forma de compensação para a garantia ser oferecida. É comum utilizar o reembolso total como compensação da falha, mas nem sempre é a melhor opção, conforme visto anteriormente. Uma compensação sem muito esforço por parte da organização também não pode ser suficiente para estimular a empresa a buscar melhorias constantes na qualidade do seu produto/serviço;

- Definindo limitações à garantia: Com relação ao alcance das garantias, diversas empresas impõem limites, buscando reduzir acionamentos injustificados. Porém estas restrições se traduzem em uma garantia mais fraca e não transmite confiança a seus clientes;

- Questionando a adoção de uma única garantia: Um outro ponto a ser analisado consiste em verificar casos em que a empresa possui diferentes 
tipos de clientes e diversas unidades de negócios, podendo não ser sensato oferecer uma garantia única;

- Apresentando a garantia ao mercado: Com relação à apresentação da garantia ao mercado, é importante aliar o maior impacto mercadológico possível da garantia à certeza de que os clientes estão conscientes da garantia oferecida, de maneira a contatá-los no caso de ficarem insatisfeitos;

- Experimentando a garantia: Antes de oferecer a garantia no mercado, é interessante considerar a idéia de a empresa implementar a garantia apenas em fase de teste, com o objetivo de identificar as possíveis falhas que certamente ocorrerão e se os resultados estão de acordo com o esperado. Desta forma, se a empresa decidir não continuar com a garantia, o impacto será menos prejudicial em relação ao relacionamento com os clientes;

- Mantendo a garantia dinâmica: A garantia, quando em funcionamento, não deve ser necessariamente imutável, podendo ser modificada posteriormente, resolvendo defeitos da garantia original ou aproveitando possíveis novas oportunidades no mercado ou na empresa. Além disso, nem em todos os casos a garantia precisa ser alterada, mas somente alguns aspectos relacionados a ela, como seu mecanismo de acionamento.

\subsection{Garantia Extraordinária}

A garantia extraordinária é definida por Hart apud Figueiredo (2005) como a que promete alta qualidade e satisfação incondicional do cliente, ao apoiar esta promessa com compensações cujo objetivo é resgatar a boa vontade do cliente em manter a sua fidelidade à empresa. Isto força a empresa a mudar radicalmente a sua organização, pois se precisar pagar por suas falhas, a baixa qualidade terá um custo insuportável para a empresa.

Para que uma garantia seja extraordinária, ela deve ir além dos padrões estabelecidos naquele negócio, do que a concorrência está fazendo, do que os clientes poderiam ter imaginado ou até mesmo além do que a empresa acreditou ser possível realizar (Hart 1996, apud Figueiredo 2005). 
Geralmente, a simples oferta de garantia adicional tem pouco impacto em clientes atuais e potenciais. Afinal, certo grau de garantia protetiva é exigido por lei e quase todos os clientes esperam encontrar algum tipo de garantia formal acompanhando virtualmente qualquer produto que comprem. A criação de uma garantia extraordinária vem de um esforço especial por parte da empresa e Hart apud Figueiredo (2005) observa que este esforço pode ser feito de diversas maneiras: Ao dramaticamente estenderem a amplitude ou duração da garantia, ou ao oferecerem uma garantia que vá além da devolução do dinheiro, ou ao oferecerem uma garantia incondicional de satisfação, que permita ao cliente devolver o produto, mesmo que não tenha ocorrido nada errado com ele.

Para Hart apud Figueiredo (2005), a implantação de um programa de garantia extraordinária por parte da empresa, não pode ocorrer de forma exclusiva entre os diversos setores, pois existe a necessidade de se estabelecer formas de garantias internas para que a empresa alcance os objetivos propostos com a implantação em todos os níveis. O maior risco que um programa de garantia extraordinária corre é ser mal preparado ou implantado sem o cuidado necessário, pois o custo das compensações pode ultrapassar os benefícios do mercado.

\subsection{Definição de Garantia quanto a Custos}

O gerenciamento financeiro da garantia é complexo, sendo um processo difícil de ser compreendido. Também ocorre de ser muito rentável para as empresas e serve como o primeiro canal de entrada para as empresas quanto à satisfação dos clientes perante os produtos oferecidos no mercado (Spraker, 2006).

O gerenciamento financeiro da garantia tem ganhado maior visibilidade nos últimos tempos em função de dois novos recentes desenvolvimentos. As condições de concorrência do mercado podem ser o maior incentivo para alguns fabricantes, para outros, o atendimento ao Código de Proteção e Defesa do Consumidor (Spraker, 2006). 
O mercado de manufatura tem sido direcionado para o ponto em que os produtos tem sido produzidos por várias empresas, alguns até mesmo nas mesmas fabricas. Este direcionamento tem forçado as empresas a diferenciarem-se entre elas através dos serviços de pós-vendas entre as organizações. As maiores organizações entendem que para serem bem sucedidas, devem capturar, entender e vincular o retorno de cada cliente para o seu ramo de atuação (ou para o seu plano de negócios). Talvez a maior riqueza de informações e completamente subutilizada, seja o retorno do cliente junto aos programas de garantia, especificamente para a definição das despesas de garantias (Spraker, 2006).

Com o objetivo de se entender o que realmente impacta nas despesas de garantia, é necessário primeiramente para os departamentos financeiros das empresas responderem à pergunta "O que é garantia?" e depois agregar todas as despesas envolvidas (Spraker, 2006).

Desde a definição de que garantia tem influência no resultado financeiro das empresas, ter o diálogo interno de "O que é garantia?" é um valioso exercício para as empresas. Outra possível dúvida é a de que a garantia é dada ou vendida? Alguns podem sugerir que no ambiente de negócios atual, a garantia tem sido vendida. Como os produtos tem sido projetados para reduzir as despesas, não é incomum para as empresas que busquem um diferencial de mercado mudar o mercado no pós-vendas, mais especificamente no que se refere à garantia e garantia estendida (Spraker, 2006).

A definição das despesas de garantia não é simples e requer conhecimento de toda a cadeia de garantia. A cadeia de garantia pode diferir dependendo de muitos fatores, como o tipo de indústria, tamanho da organização e processos de negócios (Spraker, 2006).

Ainda segundo Spraker (2006), as despesas de garantia podem ser divididas em dois componentes: Despesas Diretas e Despesas Indiretas. Assim que divididas em dois componentes, tem-se a composição das despesas em garantia baseadas em duas fontes: 


$$
\mathrm{GDG}=\mathrm{DD}+\mathrm{DI}
$$

Onde:

GDG = Gerenciamento de Despesas em Garantia;

DD = Despesas Diretas;

DI = Despesas Indiretas.

As figuras reportadas para as despesas de garantia são os montantes que incluem ambas as despesas diretas e indiretas. Os termos aqui indicados podem variar de organização para organização e eventualmente podem não ser aplicadas para todos os ramos de atuação no mercado (Spraker, 2006).

Despesas Diretas são os lançamentos financeiros ocorridos quando da atuação direta na entrega, reparo, substituição ou renovação de um produto. Estas despesas podem ser expressas da seguinte forma:

$$
D D=P C 1+P C 2+P C 3
$$

Onde:

DD = Despesas Diretas;

PC1 = Retorno de Material e Processo de Administração de Despesas Transacionais; PC2 = Despesas de Estrutura Física Para Garantia; PC3 = Despesas de Serviços de Reparo, Substituição ou Renovação.

Montando um modelo para associar estas áreas com cada família de produto é possível e desejável. Isto fará com que seja mais fácil de automatizar os lançamentos e mudanças nos respectivos modelos: Despesas de garantia, reservas de garantia, reconhecimento da receita e contratos de serviços.

Assim podemos ter a seguinte composição: 
PC1 = Retorno de Material e Processo de Administração de Despesas Transacionais

- Envio/recebimento da reclamação em garantia;

- Armazenagem/retenção da reclamação em garantia;

- Lançamentos de mão de obra dos empregados diretos (processamento da informação);

- Lançamentos de mão de obra dos empregados terceirizados (processamento da informação);

- Lançamentos de viagens;

- Equipamentos/materiais/ softwares de utilização;

- Despesas adicionais de mão de obra;

- Despesas de treinamento.

PC2 = Despesas de Estrutura Física Para Garantia

- Lançamentos de mão de obra dos empregados diretos (processamento da informação);

- Lançamentos de mão de obra dos empregados terceirizados (processamento da informação);

- Lançamentos de viagens;

- Peças diretas/despesas de material para o reparo/ substituição/renovação;

- Despesas adicionais de mão de obra;

- Despesas de treinamento;

- Equipamentos de teste;

- Despesas de transporte.

PC3 = Despesas de Serviços de Reparo, Substituição/ Renovação

- Lançamentos de mão de obra dos empregados diretos (processamento da informação);

- Lançamentos de mão de obra dos empregados terceirizados (processamento da informação);

- Lançamentos de viagens; 
- Peças diretas / despesas de material para o reparo / substituição / renovação;

- Despesas de mão de obra adicional;

- Despesas de treinamento;

- Equipamentos de teste;

- Despesas de transporte.

As despesas indiretas são os lançamentos ocorridos para o suporte do gerenciamento do produto. As despesas indiretas podem diferir dependendo da organização e pode ser de difícil obtenção quando requerem suposições e entradas manuais no livro-razão.

$$
\mathrm{DI}=\mathrm{SC} 1+\mathrm{SC} 2+\mathrm{SC} 3+\mathrm{SC} 4+\mathrm{SC} 5+\mathrm{SC} 6
$$

Onde:

DI = Despesas Indiretas;

SC1 = Recuperação de despesas (créditos e débitos);

SC2 = Atividades relacionadas a centro de atendimentos de garantia;

SC3 = Inventário relacionado à garantia;

SC4 = Registro de garantia;

SC5 = Despesas do processo de análise de garantia;

SC6 $=$ Despesas de disponibilidade de equipamentos.

Muitas das despesas indiretas são colocadas como parte do volume de entrada no livro razão das empresas e são difíceis de serem automatizados. O enfoque típico para estes tipos de despesas é a divisão em grupos. Isto significa que a razão de uma despesa (por exemplo, o centro de atendimento a clientes) pode ser alocada em diferentes grupos de despesas (garantia, garantia estendida, investigações técnicas, etc.). Por exemplo, SC2 poderia ser calculado manualmente (por exemplo, com a suposição de que $25 \%$ das despesas são dirigidas por chamadas de garantia, então $0,25 \times$ despesa de centro de atendimentos a clientes $=\mathrm{SC} 2$ ), entretanto, é possível automatizar certos passos do processo. 
SC1 = Recuperação de despesas (créditos e débitos)

- Recuperação dos Vendedores: Estas despesas estão associadas com a recuperação financeira das despesas com substituição/reparo de terceiros. Isto pode incluir despesas com disputas judiciais;

- Despesas dos Vendedores com Garantia: Despesas de compra de peças junto a fornecedores;

- Despesas com Vendedores e Fabricantes: Créditos oriundos de compras de componentes com falhas epidêmicas (pode ser consideradas como créditos nas despesas com vendedores);

- Despesas de Recuperação (retorno das despesas): Despesas recuperadas através de auditorias de garantias em oficinas/distribuidores/clientes baseados em pagamentos prévios de reclamações/reparos indevidos.

SC2 = Centro de Atendimento

- Despesas internas ou terceirizadas para suporte técnico dos termos de garantia - Quebra/conserto;

- Despesas internas ou terceirizadas para suporte não técnico (exemplos: Perguntas sobre utilização, aprovações/autorizações);

- Despesas internas ou terceirizadas referentes à comunicação (e-mail, whiteboard, etc.) de suporte ao produto durante o período de garantia;

- Despesas internas ou terceirizadas referentes a desenvolvimento, suporte e manutenção de web durante o período de garantia;

- Despesas de mão de obra adicional para o centro de atendimento ou centros de suporte (aluguéis, locações, pessoal da administração, etc.).

SC3 = Inventário

- Despesas diretas de compras e estocagem de peças dedicadas à substituição em garantia; 
- Despesas por terceirizados de compras e estocagem de peças dedicadas à substituição em garantia;

- Despesas logísticas por fretes, distribuição, gerenciamento de peças e mão de obra adicional associada;

- Despesas de reembolso ao vendedor ou concessionário por suas despesas ao adquirir e estocar peças dedicadas à substituição em garantia;

- Despesas de inventário;

- Gerenciamento e documentação de retorno e obsolescência.

SC4 = Registros de Garantia

- Despesas com tecnologia ou equipe de suporte para registrar denominações de garantia para compras de clientes;

- Despesas com equipe de suporte e administração;

- Despesas com produção e administração de documentos de registros;

- As despesas internas (algumas empresas usam empresas terceirizadas) em obter, manter, validar, e reportar a entrega da informação de produtos seriados.

SC5 = Despesas do Processo de Análise de Garantia

- Lançamentos de mão de obra de empregados diretos (análise das informações);

- Lançamentos de mão de obra dos empregados terceirizados (análise das informações);

- Lançamentos de viagens;

- Software/equipamentos/materiais;

- Gastos adicionais com mão de obra;

- Despesas de treinamento. 
SC6 = Despesas de disponibilidade de equipamentos

- Despesas de disponibilidade de produtos/reciclagem: Despesas associadas em seguir leis governamentais referentes à depreciação, reciclagem ou disponibilidade de equipamentos e produtos.

\subsection{Conceitos de Falhas e Confiabilidade}

\subsubsection{Conceitos de Confiabilidade}

Segundo Martha de Souza (2003), confiabilidade é a probabilidade de um produto, sistema, máquina, ou equipamento operar, dentro das especificações para as quais foi projetado e construído, por um tempo determinado.

Ainda, conforme Martha de Souza (2003), uma outra forma de conceituar confiabilidade é: "a probabilidade de que um sistema ou equipamento sobreviva por um período de tempo específico".

Se uma empresa automotiva aumenta a confiabilidade de seus produtos, ela consequentemente aumentará os custos de projeto ou de produção. O custo total de um veículo não é calculado baseando-se somente no custo de quando o veículo deixa a fábrica, mas sim com todo o custo até o final de seu período de garantia. $\mathrm{Na}$ aprovação de um projeto, todos os gastos esperados e retorno do investimento estão incluídos, inclusive os gastos estimados de garantia durante a vida útil do produto. A Figura 6 conforme O'Connor, (2002), é uma representação teórica da relação custo benefício dos esforços gastos em atividades da análise de confiabilidade. Porém, apesar de seu apelo e uso freqüente, esta figura não reflete totalmente a realidade. Sabe-se que nunca será atingida a confiabilidade perfeita, ou seja, 100\%. 


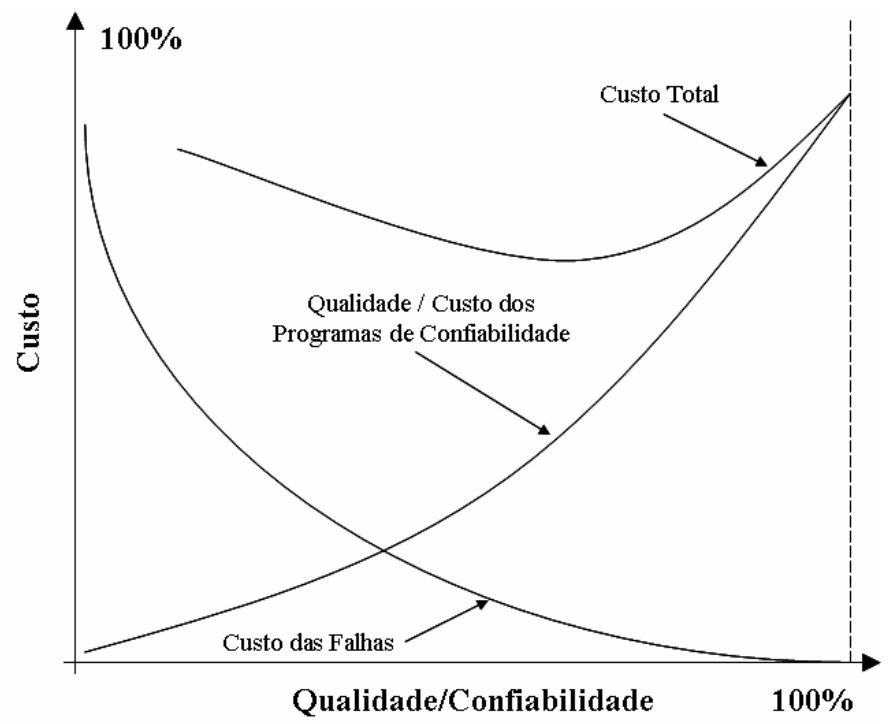

Figura 6 - Confiabilidade e Custos do Ciclo de Vida (Connor, 2002)

\subsubsection{Classificação e Definição da Falha}

Segundo Martha de Souza (2003), a falha de determinado produto causa aumento de custos e inconveniências para o cliente e, em casos específicos, pode comprometer aspectos de segurança dos usuários e da população em geral.

Martha de Souza (2003), afirma que o comportamento de um determinado produto com relação à falha, é mais bem compreendido pelo exame do comportamento da sua taxa de falha.

Esta taxa de falha $\lambda(t)$ pode ser definida em termos da própria confiabilidade como segue:

"Sendo $\lambda(t) \Delta t$, a probabilidade de que o sistema falhará em um tempo $t<\Delta t+$ $\Delta t$, dado que ainda não falhou até o tempo $t=t$, tem-se que $\lambda(t) \Delta t$ é a probabilidade condicional:" 


$$
\lambda(t) \Delta t=\mathrm{P}(\boldsymbol{t}<\Delta t+\Delta t \mid \boldsymbol{t}>t)
$$

Assim, com base na definição de probabilidade condicional, tem-se:

$$
P(\boldsymbol{t}<\Delta t+\Delta t \mid \boldsymbol{t}>t)=\mathrm{P}\{(\boldsymbol{t}>t) \cap(\boldsymbol{t}<\Delta t+\Delta t) / \mathrm{P}(\boldsymbol{t}>t)
$$

Como o numerador de equação (6) é a própria $f(t) \Delta t$ e o denominador é a $R(t)$, vem:

$$
\lambda(t)=f(t) / R(t)
$$

Ou seja, $\lambda(t)$ expressa a taxa de falha instantânea.

Assim:

$f(t)$ : Função densidade de probabilidade falha;

$R(t)$ : Confiabilidade.

A falha prematura é o resultado de defeitos introduzidos durante qualquer fase do processo de manufatura ou na montagem do produto e normalmente está relacionada a algum tipo de erro humano. Falha aleatória é o defeito de componentes submetidos a carregamentos inevitáveis e inesperados e são falhas inerentes ao produto. A falha por desgaste dos mecanismos ocorre como resultado de um uso prolongado e exposição ao meio ambiente queira ocorrer a toda a população que estiver em uso prolongado (Connor, 2002). A Figura 7 mostra a curva da banheira, onde as três classes de falhas estão representadas: 


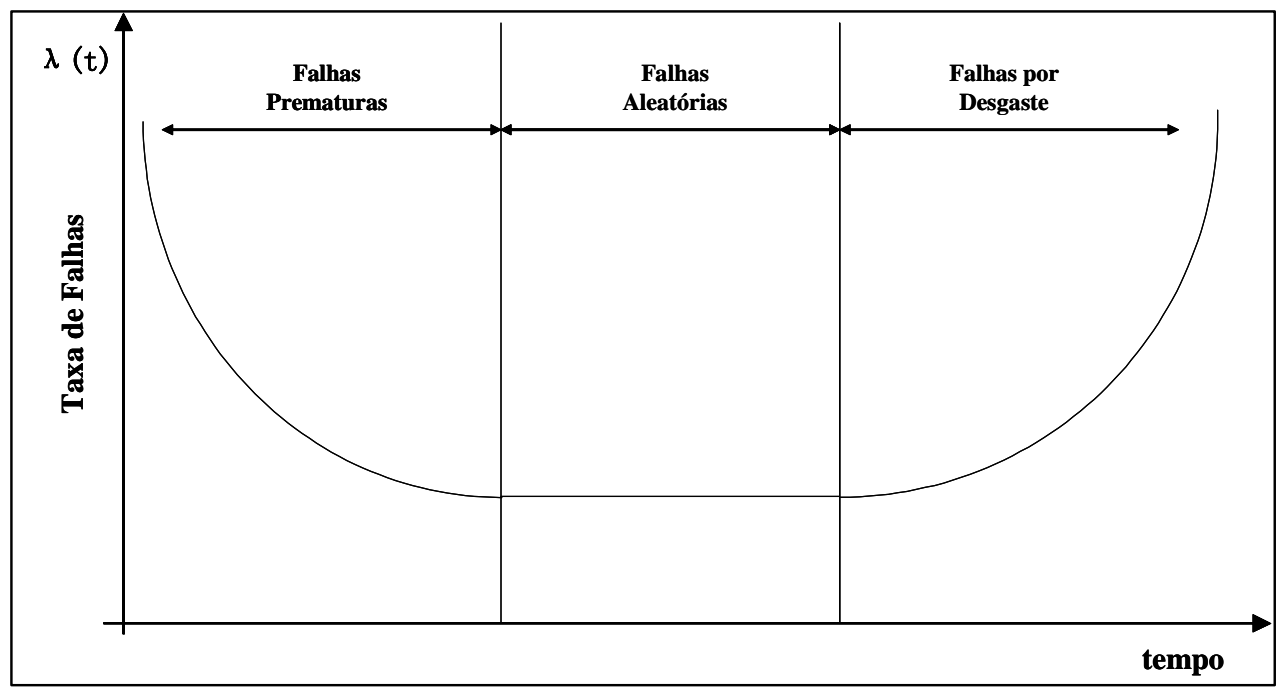

Figura 7 - Representação Gráfica da Curva da Banheira (Connor, 2002)

Sempre dentro do período de garantia, o cliente é protegido caso o produto falhe uma, duas, ou várias vezes, visto que o contrato especifica que o fabricante substituirá ou reparará o produto durante o prazo de garantia. Se o produto falhar muitas vezes, o fabricante sofrerá com altos custos de garantia e o cliente sofrerá com inconveniências causadas pela falta de confiabilidade do produto. Fora do período de garantia, somente o cliente sofrerá, mas em qualquer dos casos, o fabricante sofrerá com danos à imagem da empresa.

Outro fator muito importante é que o fabricante promete reparar ou substituir o produto, apenas se o usuário utilizar o produto conforme os requisitos operacionais indicados normalmente em manuais de produto. Os manuais são uma forma de os fabricantes se protegerem do uso indevido do produto, como em condições operacionais fora das especificações, ou mau uso através de recomendações operacionais ao cliente.

As especificações operacionais recomendadas pelo fabricante podem ser vistas como uma forma de o fabricante se proteger da falta de robustez de seu produto em operar em diversos ambientes e com diversos fatores afetando-o.

A dificuldade em exemplificar critérios de falha é que normalmente a classificação pode ser muito subjetiva e diferentes clientes podem ter diferentes expectativas em 
relação ao desempenho de um determinado produto. Também pode haver uma diversidade entre usuário e fabricante em relação ao que é exatamente um desempenho degradado ou falha (Blashe, 1991).

Defeitos como mudanças na aparência ou uma degradação menor que não afetem a função (desempenho) não são relevantes para a confiabilidade de um produto. Porém, uma degradação percebida é uma indicação de que uma falha poderá ocorrer e, portanto tais incidentes devem ser considerados como falha.

Para a confiabilidade, o defeito é uma característica que não afeta a função desempenho e a falha é uma característica que afeta a função desempenho.

O critério de classificação de falha utilizado por Blashe (1991) é mostrado na Figura 8:

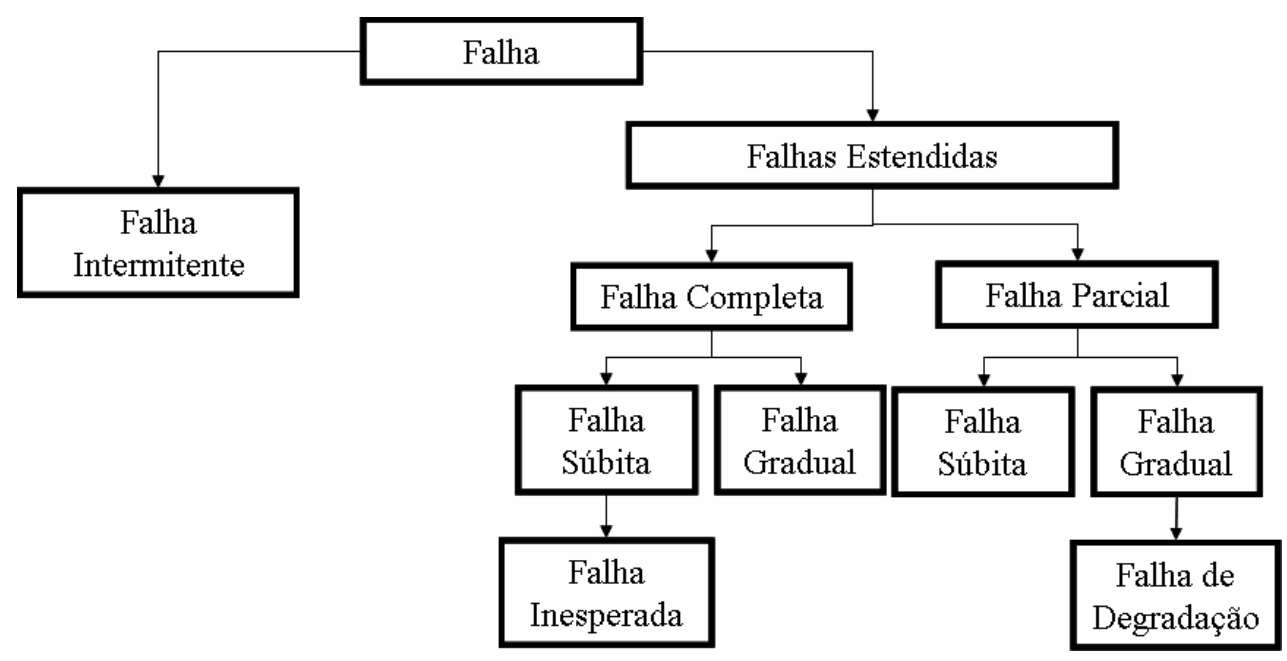

Figura 8 - Método de Classificação das Falhas (Blashe, 1991)

A definição de cada tipo de falha é descrita a seguir:

Falha Intermitente: Falha que resulta na falta de alguma função do produto, apenas por um determinado período de tempo. O componente retorna completamente ao seu estado funcional imediatamente após o evento de falha. 
Falha Estendida: Falha que resulta na ausência de algumas funções, e que perdurará até que as partes falhadas sejam substituídas ou reparadas. As falhas estendidas são divididas em dois tipos:

- Falha Completa: Falha que causa uma falta completa de uma função exigida;

- Falha Parcial: Falha que conduz à ausência de algumas funções, mas não como a falha completa, pois se pode utilizar redundâncias para contornar o problema até que a falha seja corrigida.

Ambas as falhas, completa e parcial ainda podem ser classificadas de acordo com a subtaneidade que ocorreu a falha:

Falha Súbita: Falha que não poderia ser prevenida através de testes e inspeção;

Falha Gradual: Falha que poderia ser prevista através de testes e inspeção;

As falhas ainda podem ser combinadas para atingir a seguinte classificação:

Falhas Inesperadas: Falhas que são ambas súbitas e completas;

Falhas de Degradação: Falhas que são ambas parcial e gradual.

As falhas, além do que fora colocado acima, segundo Blashe (1991) podem ser classificadas como:

Falhas de Desgaste: Falhas atribuídas ao processo normal de desgaste de um equipamento;

Falhas de Mau Uso: Falhas atribuídas à aplicação de tensão de carregamento, além das capacidades especificadas no componente;

Falhas Inerentes a Fragilidade: Falhas devido a erros de projeto, produção ou montagem, que faz com que o componente falhe quando sujeito a tensão de carregamento dentro das capacidades especificadas. 
Uma outra proposta de classificação de falhas é colocada pela norma militar americana MIL-STD-781(1986) que define dois tipos de falha:

Múltiplas Falhas: A ocorrência simultânea de duas ou mais falhas independentes;

Falhas Padrão: A ocorrência de duas ou mais falhas na mesma peça em aplicações idênticas ou equivalentes quando as falhas são causadas pelo mesmo mecanismo básico de falha e as falhas ocorrem a uma taxa que é inconsistente com a taxa de falhas previstas;

Falhas Independentes: Um evento independente do equipamento em teste e quaisquer falhas dependentes causados por meio das quais são consideradas como uma única falha e usada para determinar consentimento contratual com critérios de rejeição e aceitação.

A norma MIL STD-781 define ainda as seguintes categorias de falhas:

Falhas de Projeto do Equipamento: Qualquer falha causada que pode estar relacionada diretamente com o projeto do equipamento, o que significa que o projeto do equipamento causa a falha ou degradação da peça em questão, acarretando na falha do equipamento;

Falhas de Manufatura do Equipamento: Uma falha causada por falta de habilidade da mão de obra ou controle de processo inadequado durante a construção, teste, ou reparo do equipamento antes do início do uso do mesmo;

Falhas de Projeto da Peça: A falha de peças que podem ser relacionadas ao projeto inadequado das mesmas;

Falhas de Manufatura da Peça: Uma falha nas peças causada por falta de habilidade da mão de obra ou controle de processo inadequado durante a montagem, inspeção ou teste inadequado. 


\section{DADOS DE FALHAS DE CAMPO}

\subsection{Configuração dos Dados de Falhas de Campo}

Segundo Colosio; Andrade e Santos (2000), desde o início da comercialização de veículos, as reclamações de campo tem sido uma importante ferramenta para as montadoras de veículos melhorarem a qualidade de seus produtos. Com isto, as diversas áreas que estão envolvidas direta ou indiretamente na fabricação de veículos e componentes precisam aumentar a interatividade e dinamismo para poderem se adequar às constantes variações que ocorrem no volume de produção e perseguir o objetivo de manter a qualidade dos seus produtos e a satisfação dos seus clientes.

Uma das mais importantes fontes de dados de uma montadora é o seu histórico em falhas de campo, pois com estes dados torna-se possível implementar melhorias em seus produtos correntes, planejar quantidades de peças de reposição, tomar dados quanto a um possível recall, assim como definir as suas estratégias de garantia.

Segundo Muttler (1998), há uma ligação entre o rápido avanço da tecnologia e a crescente expectativa do cliente quanto à qualidade de produtos e serviços. A ligação entre o julgamento do cliente de produtos e serviços pode levar um ano ou mais para formação. O comprador de um novo automóvel pode proporcionar uma avaliação mais poderosa da qualidade em um ano ou mais que qualquer outro que o compra no momento em que este está novo.

Alaverdi e Fathi (2006) afirmam que detectar e corrigir falhas de campo e problemas operacionais tradicionalmente não tem sido foco das organizações de manufatura. De fato muitos problemas não são identificados até que o produto não chegue às mãos dos clientes, considerando que uma ação corretiva irreversível poderá levar até 12 meses depois do início das incidências das falhas no produto, como pode ser visto na Figura 9. 


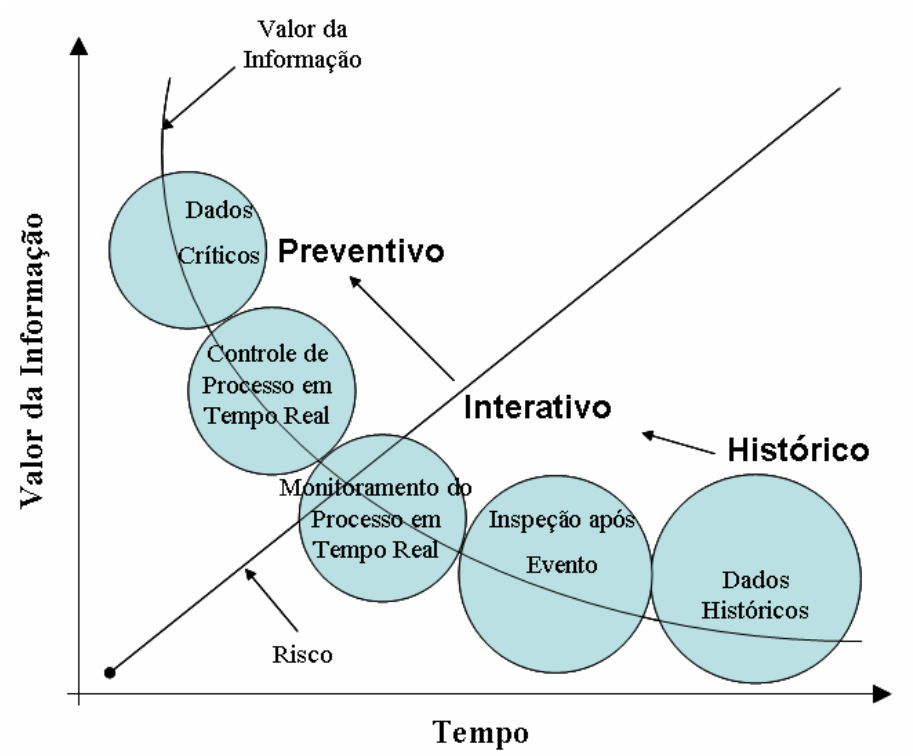

Figura 9 - Valor da Informação Diminui com o Tempo e o Risco Aumenta (Alaverdi e Fathi, 2006)

As organizações de manufatura têm sido forçadas a encontrar uma forma de melhorar qualidade de seus produtos ao mesmo tempo em que tem de reduzir custos de garantia. A resposta para este dilema reside na adoção de uma nova forma para o gerenciamento da garantia. Em oposição à função de gerenciamento da cadeia de suprimentos, as informações sobre garantia devem agora tornar-se um componente crítico no gerenciamento no ciclo de vida do produto. Este deve ser trabalhado simultaneamente com as estratégias de manufatura e suprimentos para promover oportunidades de melhoria da qualidade do produto que resultem no melhor retorno financeiro. Explorando as informações desta maneira, os fabricantes não somente melhorarão a sua habilidade em detectar e reagir diante dos problemas, mas também assegurar que estes problemas não sejam transferidos de um projeto de produto para outros projetos futuros (Alaverdi e Fathi, 2006).

As práticas de gerenciamento de qualidade não fornecem visibilidade suficiente para a qualidade do veículo e sua confiabilidade. Esta distância entre um bom ciclo de vida de um produto e seus problemas acarreta em uma enorme ineficiência no processo de melhoria de um produto na forma de problemas repetitivos e tempo excessivo no entendimento de novos problemas e alto custo de garantia. (Barkai, 2004). 
Os fabricantes e seus fornecedores conseguem as informações pertinentes à operação dos seus veículos, desempenho de reparo e satisfação dos clientes de múltiplas fontes incluindo o programa de ligações telefônicas no momento do lançamento, suporte técnico, administração de garantia, gerenciamento de garantia e grupo de suporte legal. Cada um destes grupos tem uma estrutura operacional e fluxo de trabalho distintos, com uma perspectiva única de seus papéis e responsabilidades e uma variedade muito grande de dados coletados, análises e requerimentos. Dados adicionais vêm de fontes externas como a pesquisa Quality Audit Survey (QAS) e grupos de clientes, que podem ser estendidos a fornecedores e técnicos de pós-vendas (Barkai, 2004).

Por causa de sua grande estrutura, os fabricantes e fornecedores às vezes experimentam algum tipo de atraso em analisar os dados de falhas em campo, chegar a conclusões a implementar ações corretivas. A taxa de penetração de mercado e o volume de mercado, juntamente com o atraso em definir os problemas de campo fazem com que as ações corretivas sejam implementadas depois de um tempo excessivo. (Barkai, 2004).

A maior dificuldade que os fabricantes de veículos estão enfrentando se refere a conduzir uma análise eficiente dos dados de qualidade e reclamações em garantia que possa efetivamente refletir o que está ocorrendo no campo. Os fabricantes e fornecedores codificam as reclamações dos clientes, peças falhadas e ações de reparo de forma que estas informações podem ser agregadas e apresentadas em gráficos de Pareto com estatísticas de falhas e custos de reparo em garantia. Porém, ao contrário do que normalmente pode se imaginar, este tipo de análise não é adequada nestes casos. (Barkai, 2004).

O retorno de campo é uma das etapas mais importantes do programa de confiabilidade, para que o fabricante saiba o que está ocorrendo com o seu produto no campo, pois muitas vezes os problemas são descobertos apenas após o produto ter sido disponibilizado aos clientes, devido à dificuldade de prever todas as falhas que ocorrerão com o mesmo. 
Os problemas podem ser causados por modos de falhas e/ou mecanismos que não foram testados anteriormente e/ou não observados em laboratório. Para tanto, é necessário utilizar um processo de aquisição de dados de campo, conforme Brall (1994):

- Se houver algum problema que possa ser extremamente sério, é importante aprender sobre o mesmo o mais rápido possível;

- Informações de campo devem ser utilizadas como retorno de informações para melhorar produtos futuros ou corrigir erros do mesmo produto. Informações de modos de falha são ricas para sugerir métodos de melhoria de confiabilidade;

- Impressões dos clientes, ambientes e outras condições de uso são importantes para a melhoria da confiabilidade do produto.

Os dados de confiabilidade de campo podem ser obtidos através de contatos com os clientes ou através dos dados gerados durante os prazos de garantia gerados pela assistência técnica da empresa para fornecer a retroalimentação de informações.

Os dados de confiabilidade no campo são importantes para que a empresa tenha as seguintes informações:

- Como o seu produto está se comportando no campo;

- Para implementar ações corretivas em função dos problemas ocorridos no campo e que não foram previstos nas fases anteriores do desenvolvimento do projeto;

- Para evitar incidências futuras dos mesmos modos de falhas em produtos futuros a serem desenvolvidos;

- Para verificar o custo de garantia do produto.

Um sistema de informações de falhas de campo deve ser estruturado em torno de rápidas implementações de ações corretivas e identificação de candidatos a melhorias. Este sistema terá ótimos resultados somente se os dados que chegam à empresa forem completos e precisos, envolvendo todos os fatores importantes necessários para realizar melhorias no produto (Brall,1994). Caso contrário, o 
fabricante efetuará mudanças ou melhorias sem conhecer a causa real do problema. Isto pode levar a mudanças incorretas do produto.

Um outro problema é sobre quem coleta os dados, o que também pode afetar os resultados visto que eles podem ser coletados por funcionários com diferentes conhecimentos, capacidades e motivação. A utilização de formatos padrões e procedimentos pode minimizar os erros, mas não pode por si só melhorar a habilidade dos funcionários entenderem e interpretarem o que está sendo feito. Durante o prazo de vigência de garantia, quem coleta estes dados é a assistência técnica dos concessionários. Esta não informa à empresa todos os dados necessários para que este tome uma ação precisa para corrigir o problema e evitar ocorrências futuras. Isto ocorre pela falta de incentivos e treinamento do fabricante à assistência técnica.

A Indústria Automotiva deveria ter dados de confiabilidade exatos para todos os tipos de falha, a partir do fato de que são milhões de carros disponíveis em uso que poderiam servir como um campo de provas gigante (Wolterec; Junger; Reichart, 2004).

Isto ocorre pelo fato de que nem todas as falhas ocorrem no campo são reportadas aos fabricantes. Em primeiro lugar, muitas falhas não são descobertas nas oficinas dos concessionários. Isto é especialmente verdade para os casos referentes aos veículos mais velhos, que não estão cobertos pelo período de garantia. Mesmo as falhas que são identificadas nas oficinas dos concessionários, às vezes não são reportadas para os fabricantes tampouco para os fornecedores das peças defeituosas. Isto ocorre porque estas oficinas, fornecedores e fabricantes são organizações independentes dos concessionários. O relacionamento entre estas organizações se limita a problemas de garantia e de segurança. Dentro do período de garantia, os sistemas de identificação de problemas de campo são focados exclusivamente no aspecto econômico do custo de garantia. Dados técnicos das falhas não são fornecidos adequadamente para uma análise quantitativa de confiabilidade. 
As informações provenientes dos bancos de dados não são consistentes, atribuindose isto ao fato de que a informação de campo representa somente aqueles veículos que apresentaram falhas em seus componentes ou subsistemas durante o período de garantia. Quase nada se sabe sobre os veículos que não falharam durante o período de garantia. Outra informação necessária para o bom andamento do projeto, é o conhecimento da causa raiz das falhas ocorridas. Somente com uma análise precisa das peças falhadas, pode-se encontrar a causa raiz dos problemas reportados e assim propor mudanças de projeto adequadas para chegar a resultados satisfatórios e confiáveis no campo.

Segundo Barkai (2004), o atraso na detecção de problemas ocasiona dificuldades na análise e solução dos mesmos. Na Figura 10, a rápida detecção, priorização e eficiência na análise do modo de falhas resulta em um número menor de veículos vendidos com problemas.

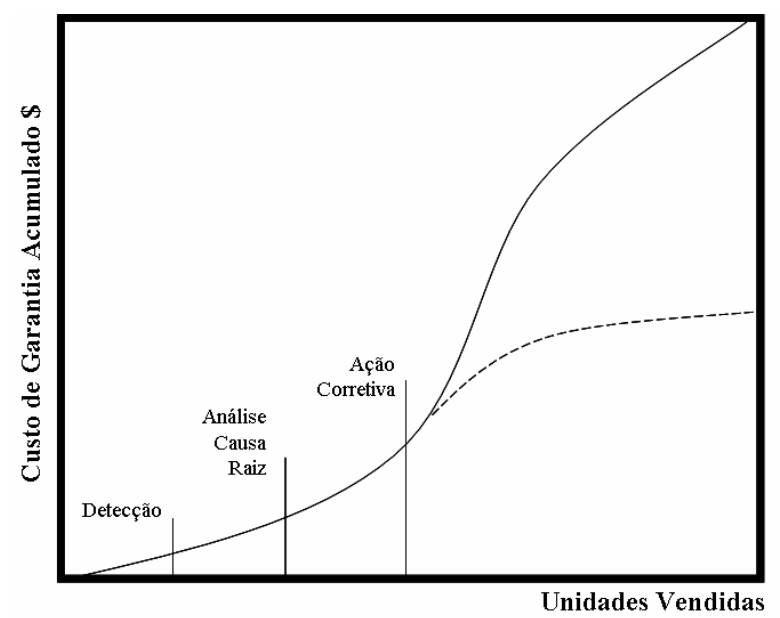

Figura 10 - Custo de Garantia Acumulado x Unidades Vendidas (Barkai, 2004)

Segundo Baxter e Tortorella (1994), na prática, os dados analisados são frequentemente os de campo, que não são sempre reunidos para o propósito de análise estatística e podem estar incompletos. Os fatores que fazem os dados de campo incompletos são:

- Tempo Incompleto de Vida: Normalmente o fabricante coleta os dados de taxa de falha de um veículo, incluindo neste tempo, períodos em que o sistema 
não estava em uso, como o tempo de armazenamento, tempo até o cliente decidir fazer o reparo no produto. Isto causa um mascaramento da verdadeira taxa de falha da peça ou componente.

- Mascaramento: Ao ocorrer uma falha em um sistema, que pode possuir vários subsistemas, e cada subsistema pode conter vários componentes, quando ocorre uma falha, a assistência técnica que faz o reparo, frequentemente substitui um módulo inteiro (subsistema), sem realizar uma análise detalhada do componente danificado contido neste módulo. Com isso, só se conhece os dados do módulo que falhou e não o componente em si e suas causas.

- Ambientes Desconhecidos: A distribuição do tempo de vida de um componente é afetada pelos ambientes em que o componente está operando. A taxa de falha aumenta sob condições adversas de tensão de carregamento, tais como temperatura, altitude, pressão, umidade, etc. Normalmente não se colhe dados sobre o ambiente operacional do componente falhado, apenas se possui conhecimento dos ambientes de um grupo de componentes.

Para Hansen e Thyregod (1991), há várias fontes que causam contaminação dos dados, algumas das quais são citadas a seguir:

- Imprecisão no registro do tempo de ocorrência de falha;

- As falhas não são detectadas instantaneamente;

- Os produtos não são operados continuamente ao longo do tempo.

Estes fatores, caso sejam ignorados, causarão um mascaramento na estimativa dos parâmetros, e no pior caso poderá haver uma estimativa errada nos custos envolvidos com as garantias. Com isto, muita atenção deve ser prestada na modelagem e avaliação destes efeitos.

Outro grande problema com a informação de confiabilidade na indústria automotiva é que as condições de uso para os veículos variam largamente. Isto inclui as mais diferentes condições ambientais de operação assim como as formas como os clientes utilizam os seus veículos. 
Segundo Colosio; Andrade e Santos (2000), os veículos são utilizados sob as mais diversas condições e por este motivo são projetados para as mais severas condições de uso. Entretanto, todos os veículos não estão livres de falhas de seus componentes que afetam negativamente na imagem junto ao cliente.

Para um fabricante de automóveis, segundo Majeske e Herrin (1995), os dados que normalmente são enviados, contém as seguintes informações: número de identificação do veículo, dados do reparo como peças trocadas, a parte que causou a falha (frequentemente é registrado como sendo um subsistema e não o componente), o modo de falha (exemplo: curto circuito na parte elétrica) e subsistema afetado pela falha (exemplo: ignição, luzes, etc.).

Embora estes dados sejam importantes para o fabricante avaliar as garantias oferecidas e os custos envolvidos, para fazer melhorias no produto ele necessita conhecer outros dados como fatores de tensão de carregamento ambiental, fatores operacionais, sintomas das falhas, diagnóstico observado durante o reparo, e os índices de medição de confiabilidade, para que ele possa fazer uma ação corretiva no sistema baseada em dados confiáveis. Estes fatores serão abordados nos itens seguintes.

\subsection{Fatores Ambientais}

Segundo Murad (2005), é necessário se preocupar com dois fatores quando se lida com ambiente de trabalho dos componentes de um veículo. Primeiramente o projeto deve ser realizado considerando a influência que o ambiente tem sobre o mesmo durante as fases de testes, estocagem, instalação e uso dos componentes.

Nesta condição o fabricante deve avaliar a severidade necessária e por quanto tempo o seu produto deve operar. Esta avaliação deve considerar todas as condições possíveis (temperatura, pressão, altitude em relação ao nível do mar, vibrações, etc.) que podem impactar no produto, assim como a sua vida útil, segurança e confiabilidade (Murad, 2005). 
A indústria automotiva procura reproduzir todas estas condições testando os seus veículos em diversas partes do país, mesmo antes do seu lançamento no mercado, incluindo nestas situações, por exemplo, a utilização de combustíveis com os mais diferentes níveis de qualidade, visto que esta é uma preocupação em comum entre todos os clientes e a indústria.

As condições ambientais devem ser revisadas periodicamente e documentadas propriamente, visto que qualquer mudança na conduta dos clientes deve ser verificada dentro destas avaliações.

O fabricante deverá conhecer todas as possíveis condições ambientais em que o produto será utilizado para que as melhorias possam ser feitas quanto ao procedimento de previsão da confiabilidade realizada nas fases anteriores do projeto, e para aumentar a robustez do seu produto para que ele possa operar em uma grande variedade de condições ambientais.

Um outro fator importante é que um teste simulando todos os fatores ambientais interagindo ao mesmo tempo, como ocorre com o produto durante o seu uso, é difícil de realizar. Portanto, dados de fatores ambientais ocorridos no campo são importantes, onde o uso real é o verdadeiro teste.

Os principais fatores ambientais que afetam a maioria dos produtos são (O'Connor, 1988):

- Vibração;

- Temperatura;

- Umidade;

- Ambiente corrosivo;

- Alta intensidade de ruído;

- Altitude;

- Poeira;

- Fungos; 
- Poluição industrial;

- Idade do lubrificante ou contaminação deste;

- Neve;

- Geada;

- Sereno;

- Orvalho;

- Outros.

Embora estes sejam os principais fatores que afetam a confiabilidade de um produto, o fabricante deve descobrir outros fatores que são exclusivos de um determinado produto. Por exemplo, para automóveis, outros fatores ambientais que podem influenciar a confiabilidade são estradas sem pavimentação, ruas de calçamento, buracos, redutores de velocidade e outros. Alguns destes fatores somente serão observados durante o reparo do produto, como a presença de poeira, fungos, condição de fluidos e etc.

\subsection{Fatores Operacionais}

Fatores operacionais são todos aqueles que se relacionam com o uso do produto. Os fabricantes normalmente fornecem juntamente com o mesmo as especificações técnicas relacionadas, como por exemplo, velocidade, potência, voltagem, e também fazem recomendações de como o usuário deve operá-lo.

O exemplo mais adequado para a limitação da garantia de veículos se refere a citação nos manuais dos veículos que serão utilizados para trabalho remunerado ou produção, em que estará sendo submetido a condições de operação mais severas. 


\subsection{Mau Uso ou Uso Indevido do Produto}

Entre os fatores operacionais do produto, um dos elementos mais críticos é o mau uso ou uso indevido por parte do cliente. O uso indevido ocorre quando o usuário não segue as especificações e recomendações dadas pelo fabricante, que normalmente estão em catálogos, em manuais, ou escritas no próprio produto.

Estas especificações dadas em manuais podem também ser vistas como uma forma de o fabricante se proteger quanto à falta de robustez do seu produto, ou quanto ao mau entendimento de como o usuário operará o seu produto.

Durante o prazo de vigência da garantia, a maior dificuldade para o fabricante é conseguir provar que a falha ocorreu devido ao mau uso, visto que ele não tem controle nenhum de como o usuário opera ou usa o produto. Além disso, ele só poderá dizer que a falha ocorreu devido ao uso indevido se as recomendações estavam claramente especificadas nos manuais.

Para um automóvel, as revisões periódicas que são obrigatórias para o cliente ter direito às garantias são uma forma de o fabricante manter o controle sobre as recomendações fornecidas nos manuais, como troca de óleo e filtros em períodos pré-determinados, e também quanto ao uso inadequado, negligência ou até mesmo um acidente.

\subsection{Taxa de Potência do Produto}

Um outro fator operacional importante a ser considerado é a taxa de potência. Ela está influenciada com a potência utilizada pelo usuário para operar um produto. Normalmente os produtos são oferecidos com certa potência a serem operados. Se o usuário opera o produto com a mesma potência, isto pode causar também durante a garantia, uma quantidade maior de falhas do que aquele produto utilizado a uma taxa de potência menor. 


\subsection{Sintoma das Falhas}

O sintoma das falhas é um dado importante para o fabricante. O sintoma está diretamente relacionado com todo o comportamento da falha, até que o cliente solicite o atendimento da assistência técnica, para que esta procure entender o problema que o cliente está reportando.

\subsection{Diagnóstico Observado Durante o Reparo}

Muitas informações só são percebidas e podem ser registradas antes ou durante o reparo. Informações antes do reparo são informações superficiais que incluem vazamentos observados, oxidações, poeira, trincas, etc. Durante o reparo, outras informações importantes sobre a situação encontrada também são importantes e devem ser registradas. A justificativa para coletar tais informações é que após o reparo muitas destas não poderão mais ser observadas ou já foram adulteradas durante o reparo.

Para o estudo de confiabilidade de um veículo utilizando-se de dados provenientes de um banco de dados de falhas de campo, inúmeras variáveis que podem afetar negativamente devem ser consideradas antes de se iniciar este estudo.

Para isso, conhecer plenamente o produto e participar ativamente da fase de desenvolvimento é fundamental para que se conheça o modo de falhas durante o período em que o veículo estará sendo utilizado por seus clientes.

É evidente que alguns riscos podem ser controlados com maior facilidade e outros com maior dificuldade, porém é necessária sempre uma análise detalhada dos dados e peças falhadas, assim como também tentar se possível entrar em contato com o cliente para conseguir informações que nem sempre estão dispostas nos bancos de dados preenchidos pelos concessionários. 
O método utilizado para análise dos dados de garantia é apenas parte do programa de confiabilidade. Os dados de falhas de campo são sem dúvida a melhor fonte de informação de garantia, refletindo o desempenho dos veículos e obtendo assim as informações de uso apropriado e de ambiente de operação.

\subsection{Banco de Dados de Falhas de Campo}

Cada veículo fabricado sai da linha de montagem da fábrica com um Número de Identificação do Veículo (NIV). Este número fornece todas as características necessárias para a rastreabilidade do veículo, como código do fabricante, versão, tipo de carroceria, código do motor, ano modelo, local em que foi fabricado. No momento em que o veículo é vendido pela concessionária, a mesma registra a notificação de venda na empresa, que considera o veículo oficialmente em exposição no campo.

No momento em que o veículo entra na concessionária com uma reclamação de seu proprietário, a concessionária realiza o reparo e efetua uma solicitação de pagamento correspondente ao serviço realizado. As informações que seguem referem-se ao NIV, quilometragem em que foi reclamado o problema, código de defeito e data da reclamação. O reparo de cada componente do veículo recebe então um código de mão de obra padronizado previamente estabelecido, que é posteriormente lançado no sistema para documentar a ocorrência da reclamação do cliente em relação ao seu veículo. Esta informação é complementada como quilometragem acumulada, data de produção do veículo, data de reclamação, concessionária, código do defeito, e outros. Estes dados permitem uma completa rastreabilidade por parte do departamento de qualidade da empresa através de diversos relatórios que proporcionam focar as ações necessárias para melhorar a qualidade do produto que está sendo vendido no mercado.

A empresa recebe estes dados de toda a rede de concessionários no território nacional, que mede o desempenho da qualidade através das incidências por mil 
unidades vendidas, índice que é denominado Incidences per Thousand Vehicles (IPTV). Este índice foi criado pelas empresas automotivas americanas.

Uma ocorrência é documentada quando o cliente procura a concessionária com uma reclamação pertinente a uma falha de funcionamento dentro dos seguintes subsistemas do veículo.

- A - Pintura;

- B - Carroçaria externa;

- C - Carroçaria interna;

- D - Ar condicionado, ventilação e aquecimento;

- E - Suspensão, direção e rodas;

- $\mathrm{F}$ - Eixo traseiro;

- $\mathrm{H}$ - Freios;

- J-Motor;

- K - Transmissão;

- L - Sistema de alimentação e escapamento;

- N - Sistema elétrico;

- $\mathrm{R}$ - Acessórios.

Barkai (2004) afirma que mecanismos de falha em veículos são complexos e muitos sistemas, subsistemas e componentes falham em mais de um modo. A complexidade das tecnologias dos sistemas automotivos e o número de subsistemas comprados previnem os fabricantes de antecipar cada modo de falha, limitando a habilidade em criar uma lista completa com os tipos de reclamação e códigos de falha.

Em adição, a informação sobre os códigos de falha é altamente dinâmica. Assim como as modificações dos fornecedores são implementadas e as informações provenientes são dinâmicas como o desaparecimento de alguns modos de falha já conhecidos e o aparecimento de novos, acarretando assim na necessidade de criação de novos códigos de modos de falha (Barkai, 2004). 
Como resultado de falhas similares identificadas em diferentes códigos de falhas, acarretando em intermináveis análises de diferentes códigos nas análises de garantia (Barkai 2004).

Os códigos também exibem limitações em reunir informações suficientes para a análise de qualidade e de causa raiz. Muitas falhas envolvem uma cadeia de eventos e múltiplas peças para um único código ou mesmo múltiplos códigos que uma estrutura hierárquica possa eventualmente não capturar. No contexto de uma reclamação de cliente, as condições e modos de falha, os passos conduzidos para os técnicos reproduzirem as falhas e solucionar o problema nunca são codificados e não estão disponíveis para futuras análises (Barkai 2004).

Os códigos de falhas preenchidos pelos concessionários no sistema de garantia da empresa são:

- $1 \mathrm{~A}$ - Empenado;

- 1B - Falha de Fundição;

- 1C-Compressão;

- 1D - Quebrado;

- 1E - Queimado;

- $1 F$ - Depósito de Carvão;

- $1 \mathrm{G}$ - Lascado;

- $1 \mathrm{H}$ - Obstruído/Restrito/Bloqueado;

- $1 \mathrm{~J}$ - Danificado;

- $1 \mathrm{~K}$ - Trincado;

- $1 \mathrm{~L}$ - Cortado;

- 1M - Amassado/Dentilhado;

- $1 \mathrm{~N}$ - Rebarbas;

- 1P - Descarregada;

- $1 R$ - Não Corresponde;

- 1W - Condensação/Umidade;

- $1 Y$ - Objetos Estranhos;

- 2C - Espelhado; 
- $2 \mathrm{E}$ - Folga Excessiva;

- $2 \mathrm{~F}$ - Folga Muito Apertada;

- $2 \mathrm{G}$ - Corte Incorreto;

- $2 \mathrm{H}$ - Instalação Incorreta;

- $2 \mathrm{~J}$ - Assentamento Incorreto;

- 2K - Vedação Incorreta;

- 2L - Pressão Incorreta;

- $2 \mathrm{~N}$ - Lubrificação Insuficiente;

- 2P - Vedação Insuficiente;

- $2 \mathrm{~S}$ - Enrugado;

- $2 \mathrm{~T}$ - Torque Incorreto;

- $2 \mathrm{~W}-$ Solto.

Assim é possível a empresa verificar no banco de dados as informações de veículos reclamados com seus respectivos NIV's, mês de produção e mês da reclamação, código interno da concessionária que realizou o reparo, modo de falha e o custo total do reparo. Estes dados são de fundamental importância, pois identificam qual a quilometragem e o tempo de exposição do veículo no campo quando ocorreu a falha neste.

Os dados de confiabilidade de campo são muito importantes para que o fabricante saiba:

- Como está se comportando o seu produto no campo;

- Para propor ações corretivas em função de problemas ocorridos no campo e que não foram preditos nas fases anteriores do ciclo de vida (projeto, testes, produção, etc.);

- Para evitar ocorrências futuras das mesmas falhas em outros produtos;

- Para evitar gastos indesejados com garantias;

- Melhoria contínua do produto. 
Existe a imagem de que os dados de campo podem ter somente um valor histórico e não há o reconhecimento sobre a importância de se ter o evento falha e saber qual componente foi trocado para recuperar a falha, relatados em um formulário dos concessionários. O banco de dados, deve ainda identificar o tempo até a falha e o tempo de reparo. Esta investigação pode ser realizada pelo serviço técnico com a colaboração do usuário, com o objetivo de detectar os modos de falha do produto quando operando no campo, através da análise do componente retornado, determinando-se a causa raiz da falha. Esta descoberta pode ter um impacto significante na melhoria de qualidade do mesmo ou futuros projetos. 


\section{CÁLCULO DO CUSTO DE GARANTIA PARA VEÍCULOS POPULARES APÓS 36 MESES DE EXPOSIÇÃO NO CAMPO}

\subsection{Determinação do Custo de Garantia no Preço Final do Veículo}

Como já mencionado anteriormente, o custo de garantia é de fundamental importância para os resultados da empresa, porque depende do valor a ser pago por esta aos concessionários que repararem os veículos que estão dentro do período de garantia. O indicador é assim obtido pela razão deste custo pela receita obtida pela venda destes veículos. O custo de garantia é o valor máximo dentro da composição do custo do veículo que a empresa poderá pagar para os concessionários para que não tenha prejuízo em cada unidade vendida.

Durante a fase de desenvolvimento de um novo produto, o fabricante normalmente foca primeiramente em alcançar as especificações de desempenho e os custos de lançamento. Embora como já mencionado anteriormente, a confiabilidade de um veículo é uma grande preocupação por parte dos fabricantes, na fase inicial do projeto, os projetistas muitas vezes trabalham muito distantes dos dados de garantia (Nasser; Dey; Tryon, 2002).

Assim que o mercado para um novo produto é identificado, um objetivo inicial de custos para o lançamento deste produto é estabelecido baseado nas projeções de margem de contribuição e lucros. Equipes individuais de desenvolvimento de produto são formadas para cada nível de desenvolvimento de componentes. Desta forma, cada equipe desenvolve projetos conceituais baseados nos objetivos de custos determinados pelos gerentes de projeto. Se cada time de desenvolvimento respeitar os custos determinados a eles no início do projeto, o produto será lançado dentro dos objetivos de custos para o lançamento do mesmo, atingindo assim a projeção inicial para margem de contribuição e lucros (Nasser; Dey; Tryon, 2002).

Os departamentos de finanças e planejamento de pós-vendas das empresas começam a trabalhar em avançado na determinação dos custos dos novos produtos 
antes destes serem lançados no mercado. O custo final de um veículo é composto pelas seguintes atividades ligadas a seu projeto e produção:

- Custos de projeto;

- Custos de validação;

- Custos de manufatura;

- Custos de peças compradas;

- Custos de logística;

- Custos de melhoria de qualidade;

- Custos de garantia.

Normalmente o custo de garantia de um novo veículo a ser produzido é projetado com base no histórico de produtos correntes da empresa que tenham semelhanças no seu conteúdo técnico e o seu desempenho atual quanto a qualidade e índice de reparos na rede de concessionários.

Outro fator importante que deve ser considerado é o grau de melhorias de qualidade que é introduzido no novo veículo na ocasião do seu lançamento, o que permite projetar uma redução no custo de garantia do novo produto comparado com o produto similar já presente no mercado.

Para melhor compreensão pode-se fazer um exemplo hipotético nas Figuras 11 e 12 a seguir, onde é possível verificar a quantidade de melhorias de qualidade introduzidas no produto atual desde o ano modelo 2004, em que havia uma taxa de falhas de aproximadamente 2300 IPTV em 12 meses de exposição no campo, que representa o período total previsto de garantia, acarretando um custo de garantia de 167,05 Unidades Monetárias (UM\$) por veículo. Com todas as melhorias de qualidade implementadas no produto no período subseqüente é possível verificar uma redução da taxa de falhas para o índice 816 IPTV para o ano modelo 2006, o que representa um custo de garantia na ordem de UM\$ 84,55 por veículo. 


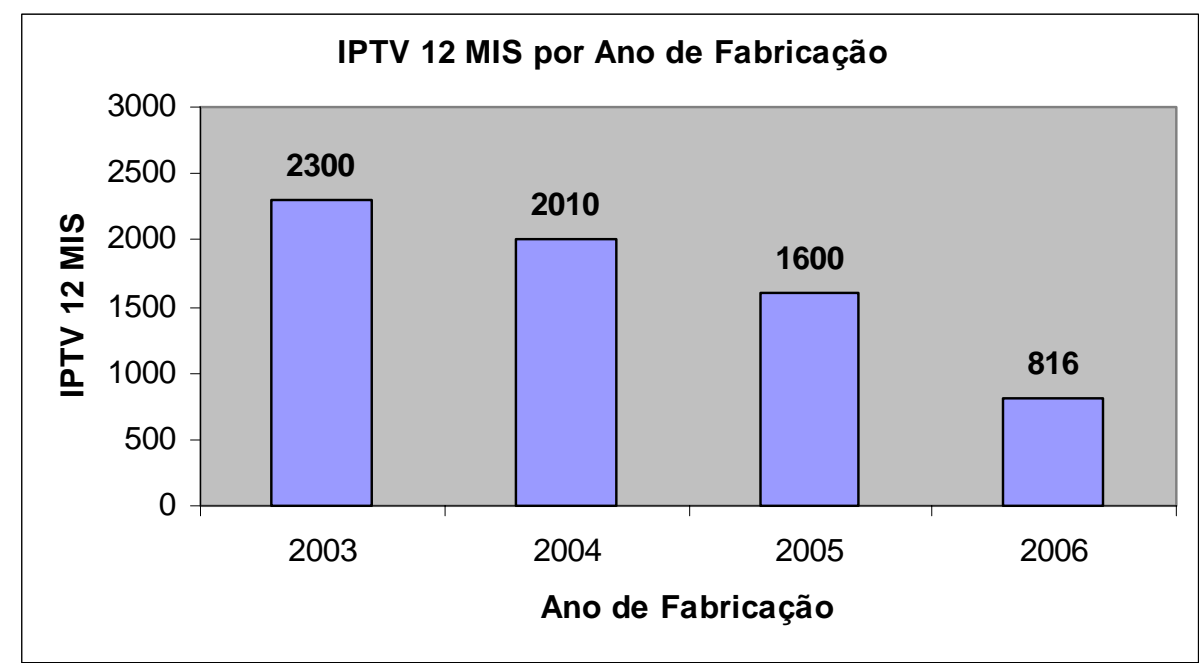

Figura 11 - IPTV 12 MIS x Ano de Fabricação

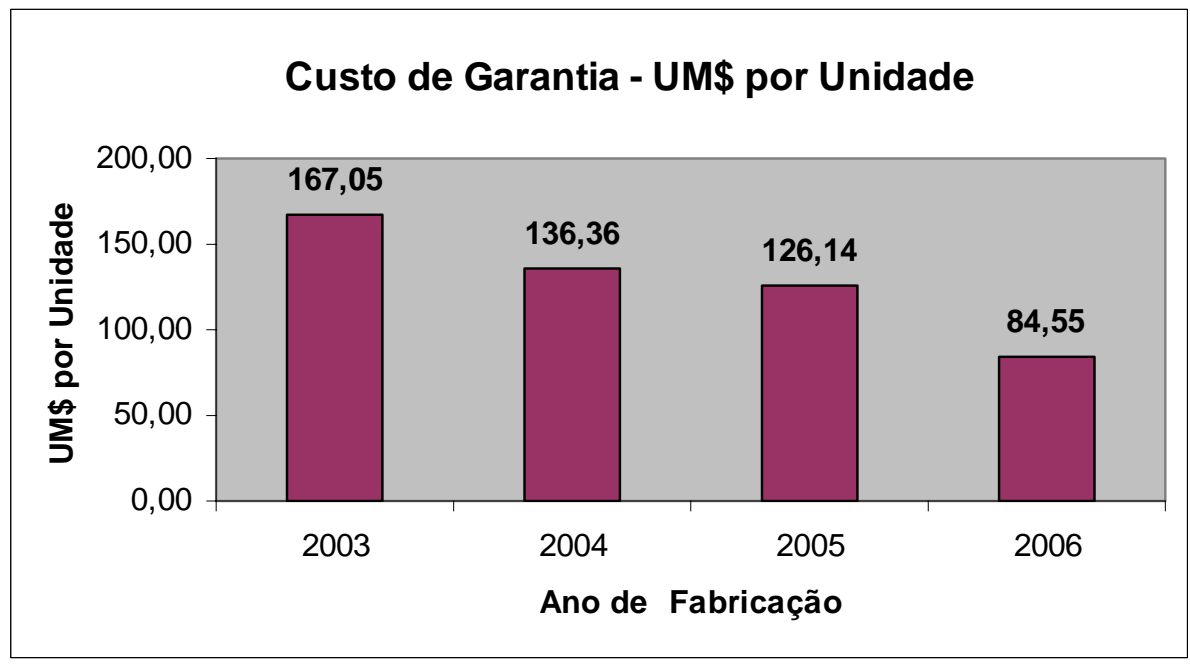

Figura 12 - Custo de Garantia x Ano de Fabricação

Assim o que se pode deduzir é que quanto maior o grau de melhorias de qualidade a serem introduzidas no novo produto, os clientes retornarão menos vezes aos concessionários para reclamar de problemas com os produtos, o que permite concluir que o retorno financeiro do produto será maior para a empresa, o que resulta também em mais uma vantagem competitiva no mercado.

Por outro lado, os grupos de engenharia do valor e redução de custos têm uma importante contribuição para a diminuição do custo final do veículo, com a 
nacionalização de itens importados e comunização de componentes entre várias plataformas de veículos.

Segundo Ventura e Varin (2002), a crescente pressão pela otimização de custos e o cenário de alta competitividade na Indústria Automotiva tem forçado as empresas a adotarem novas estratégias para gerenciar os negócios e consequentemente aumentar as margens de contribuição.

Ventura e Varin (2002) afirmam que a redução de custos não deveria ser decidida apenas pelo menor custo por peça oferecido. É óbvio que deve haver uma procura pelo menor preço, mas esta deve ser baseada em um processo de redução de custos robusto, melhoria da qualidade, aplicação de materiais de fácil obtenção e melhorias de processo.

Com esta finalidade, os grupos de engenharia do valor e redução de custos devem ser compostos por representantes das seguintes áreas, que terão a responsabilidade de suportar as decisões referentes à otimização dos produtos com o suporte das ferramentas de Engenharia do Valor (Ventura; Varin, 2002):

- Engenharia do produto;

- Fornecedores;

- Manufatura;

- Logística;

- Qualidade;

- Finanças;

- Compras.

O principal objetivo do processo da Engenharia do Valor é verificar os materiais que podem ser utilizados, processos alternativos, mudanças de projeto e nacionalização de componentes para ajustar o produto final às necessidades do mercado consumidor (Ventura; Varin , 2002).

A Engenharia do Valor é baseada nos seguintes princípios (Ventura; Varin, 2002): 
- Aumentar a margem de contribuição;

- Aumentar a competitividade no mercado;

- Evitar a deterioração da expectativa dos clientes;

- Evitar a deterioração dos custos de garantia;

- Trabalho em equipe entre todos os departamentos da empresa;

- Prover o intercambio entre peças de diferentes plataformas de veículos.

Segundo Ventura e Varin (2002), os principais objetivos da Engenharia do Valor são:

- Identificar, desenvolver e principalmente implementar oportunidades de redução de custos;

- Coordenar a certificação e validação de todas as oportunidades;

- Atingir os objetivos de redução de custos dentro do prazo programado;

- Desenvolver sistemas e componentes com fornecedores locais.

Baseando-se nos princípios e objetivos das atividades de Engenharia do Valor é possível concluir que o custo de garantia é diretamente influenciado pelas iniciativas descritas, podendo resultar positivamente em uma redução de custo no valor final do veículo, proporcionando um aumento na proporção destinada ao custo de garantia. Porém o efeito oposto poderá ser notado na eventualidade de um componente que tenha sofrido uma mudança por redução de custo mostrar-se inapropriado ou ter um desempenho abaixo do esperado, acarretando assim no aumento do custo de garantia e uma diminuição na satisfação dos clientes.

\subsection{Cálculo do Custo de Garantia Após 24 e 36 Meses de Exposição no Campo}

Os bancos de dados de falhas das montadoras de veículos normalmente apresentam os dados de reclamações dos seus clientes em visitas aos concessionários durante o período em que vigora a garantia de seus produtos. Quase todos os clientes deixam de procurar os serviços dos concessionários após o 
término do primeiro ano de garantia do veículo e consequentemente torna-se difícil a determinação do Custo de Garantia por Veículo (CPV) após este período, como determina o estudo em questão. Assim, torna-se necessária a adoção de um modelo para cálculo e previsão do custo de garantia por veículo ao final de 24 e 36 meses de exposição respectivamente.

O banco de dados de falhas de campo da empresa fornece o custo de garantia por veículo por mês de produção. O primeiro passo para o cálculo do custo de garantia por veículo é obter os valores de custo de garantia por veículo após 12 meses de exposição no campo. Para que se tenha total confiabilidade na obtenção destes dados, para este estudo serão considerados os valores de custo de garantia por veículo no período de produção entre setembro de 2004 e agosto de 2005, por considerar que na época em que foi desenvolvido o presente estudo, os veículos produzidos neste período reconhecidamente já tenham sido expostos no campo por 12 meses. Os dados dispostos na Tabela 2 abaixo se referem aos valores de custo de garantia por veículo, considerando as unidades produzidas entre setembro de 2004 e agosto de 2005, vendidos somente ao mercado brasileiro, excluindo os valores gastos pelos concessionários em veículos que sofreram recalls e atendimentos especiais nos concessionários. Estes critérios serão extensivos a todos os indicadores utilizados neste estudo:

Tabela 2 - Custo de Garantia por Veículo por Meses de Exposição no Campo (12 meses)

\begin{tabular}{|l|c|c|c|c|c|c|c|c|c|c|c|c|c|}
\hline Mês de & \multicolumn{10}{|c|}{ Meses em Exposição no Campo } \\
\cline { 2 - 14 } \\
\cline { 2 - 13 } & 0 & 1 & 2 & 3 & 4 & 5 & 6 & 7 & 8 & 9 & 10 & 11 & 12 \\
\hline set/04 & 1,20 & 6,70 & 12,74 & 18,60 & 24,93 & 31,20 & 39,80 & 49,50 & 59,66 & 70,67 & 81,68 & 94,81 & 115,04 \\
\hline out/04 & 0,17 & 3,55 & 8,04 & 13,28 & 18,84 & 25,33 & 33,92 & 43,16 & 52,37 & 62,72 & 73,59 & 84,73 & 101,01 \\
\hline nov/04 & 0,48 & 4,69 & 10,97 & 16,85 & 25,26 & 33,40 & 40,99 & 51,63 & 63,79 & 76,46 & 89,78 & 103,88 & 121,01 \\
\hline dez/04 & 1,09 & 7,80 & 13,51 & 19,73 & 25,49 & 32,74 & 41,86 & 51,50 & 62,49 & 73,57 & 86,49 & 98,13 & 118,72 \\
\hline jan/05 & 0,97 & 6,24 & 11,14 & 15,66 & 22,51 & 30,94 & 42,52 & 54,48 & 66,50 & 80,07 & 92,63 & 106,21 & 124,00 \\
\hline fev/05 & 0,53 & 6,86 & 13,30 & 19,52 & 27,62 & 37,70 & 50,89 & 65,09 & 79,70 & 93,01 & 106,16 & 123,29 & 148,42 \\
\hline mar/05 & 0,73 & 6,15 & 12,09 & 17,14 & 24,32 & 33,30 & 42,67 & 54,25 & 65,19 & 75,95 & 88,51 & 103,16 & 122,58 \\
\hline abr/05 & 0,69 & 5,59 & 12,16 & 20,30 & 28,28 & 37,52 & 47,45 & 59,68 & 72,27 & 84,94 & 98,65 & 111,69 & 129,23 \\
\hline mai/05 & 0,07 & 4,13 & 9,34 & 14,73 & 22,14 & 29,96 & 40,79 & 49,52 & 61,18 & 75,75 & 88,49 & 102,12 & 122,74 \\
\hline jun/05 & 0,64 & 6,52 & 12,66 & 19,87 & 27,46 & 33,86 & 42,92 & 53,30 & 63,10 & 73,87 & 83,49 & 94,55 & 115,55 \\
\hline jul/05 & 1,01 & 7,94 & 14,77 & 22,95 & 31,37 & 40,34 & 50,42 & 60,72 & 72,80 & 84,71 & 96,36 & 108,36 & 127,61 \\
\hline ago/05 & 1,11 & 9,04 & 18,58 & 27,72 & 36,76 & 48,76 & 59,45 & 73,71 & 87,27 & 99,31 & 112,93 & 127,40 & 148,01 \\
\hline Média & 0,73 & 6,32 & 12,57 & 19,06 & 26,48 & 34,91 & 44,76 & 55,87 & 67,55 & 79,55 & 91,91 & 105,25 & 124,84 \\
\hline
\end{tabular}

Em função da possibilidade do custo de garantia por veículo ser composto por atendimentos em que os problemas reclamados pelos clientes sejam de natureza prematura, é necessário obter do banco de dados um novo valor de custo de garantia para veículos que tenham falhado após o período em que as falhas são 
prematuras. Para a obtenção deste valor será obtido o custo de garantia por veículo da mesma forma para aqueles com 12 meses de exposição no campo como demonstrado anteriormente, porém agora com uma restrição no banco de dados para que determine o valor de custo de garantia para aqueles veículos que tenham atingido simultaneamente 8 meses de exposição no campo e que tenham quilometragem mínima de $15.000 \mathrm{~km}$, quilometragem esta que excede a quilometragem media anual de $12.800 \mathrm{~km}$ que o motorista brasileiro percorre segundo dados de pesquisa da Gipa (2006). Estes dados obtidos do banco de dados de falhas de campo estão representados na Tabela 3:

Tabela 3 - Custo de Garantia por Veículo por Meses de Exposição no Campo (8 meses e 15.000 km)

\begin{tabular}{|l|c|c|c|c|c|c|c|c|c|}
\hline \multirow{2}{*}{$\begin{array}{c}\text { Mês de } \\
\text { Produção }\end{array}$} & \multicolumn{10}{|c|}{ Meses em Exposição no Campo } \\
\cline { 2 - 11 } & 0 & 1 & 2 & 3 & 4 & 5 & 6 & 7 & 8 \\
\hline set/04 & 0,00 & 0,00 & 0,00 & 0,02 & 0,18 & 0,51 & 1,37 & 2,72 & 4,65 \\
\hline out/04 & 0,00 & 0,00 & 0,00 & 0,05 & 0,30 & 0,63 & 1,42 & 2,82 & 4,72 \\
\hline nov/04 & 0,00 & 0,00 & 0,02 & 0,10 & 0,23 & 0,61 & 1,32 & 2,97 & 5,53 \\
\hline dez/04 & 0,00 & 0,02 & 0,02 & 0,07 & 0,13 & 0,40 & 1,14 & 2,26 & 3,99 \\
\hline jan/05 & 0,00 & 0,00 & 0,00 & 0,05 & 0,33 & 1,27 & 3,10 & 5,30 & 8,05 \\
\hline fev/05 & 0,00 & 0,00 & 0,00 & 0,05 & 0,43 & 1,52 & 3,02 & 5,33 & 8,46 \\
\hline mar/05 & 0,00 & 0,00 & 0,02 & 0,03 & 0,36 & 0,97 & 2,05 & 4,17 & 6,32 \\
\hline abr/05 & 0,00 & 0,00 & 0,02 & 0,08 & 0,28 & 1,12 & 2,43 & 4,70 & 7,36 \\
\hline mai/05 & 0,00 & 0,00 & 0,00 & 0,10 & 0,45 & 1,12 & 2,48 & 3,93 & 6,17 \\
\hline jun/05 & 0,00 & 0,00 & 0,00 & 0,18 & 0,58 & 1,19 & 2,23 & 3,93 & 5,36 \\
\hline jul/05 & 0,00 & 0,00 & 0,02 & 0,05 & 0,18 & 0,81 & 1,91 & 3,18 & 5,81 \\
\hline ago/05 & 0,00 & 0,00 & 0,00 & 0,05 & 0,26 & 1,16 & 2,49 & 5,12 & 7,84 \\
\hline Média & 0,00 & 0,00 & 0,00 & 0,07 & 0,30 & 0,92 & 2,05 & 3,84 & 6,17 \\
\hline
\end{tabular}

Porém o banco de dados de falhas de campo não é capaz de determinar o tamanho da população de veículos no campo que já tenham ultrapassado a faixa superior aos $15.000 \mathrm{~km}$ rodados, uma vez que trabalha somente com o número absoluto de falhas. Com isto é necessário utilizar um fator de correção para a determinação da população destes veículos.

Para a determinação deste fator, foram utilizados como referência os dados extraídos da pesquisa QAS, que mede a satisfação dos clientes do mercado brasileiro após os primeiros 3 meses de contato destes com os veículos comprados nos concessionários. 
Porém para se saber a quilometragem que um veículo deve ter aos 3 meses de exposição no campo para chegar aos 15.000 km em 8 meses de exposição no campo é necessário estabelecer a seguinte correlação:

$$
\begin{aligned}
8 \mathrm{MIS}> & =15.000 \mathrm{~km} \\
3 \mathrm{MIS}> & =X \mathrm{~km} \\
X & =5.600 \mathrm{~km}
\end{aligned}
$$

Com base na correlação de quilometragem na regra matemática aplicada entre as equações (8) e (9), a empresa contratada pelas montadoras responsável por realizar as entrevistas com os clientes pesquisados forneceu o percentual dos entrevistados em que os clientes já haviam ultrapassado 5.600 km em 3 meses de utilização do veículo, o que pela média fará com que o cliente venha a rodar $15.000 \mathrm{~km}$ no período de 8 meses, que corresponde a 16\% dos veículos cujos proprietários foram entrevistados.

Este fator deve ser então aplicado nos dados de custo de garantia por veículo em 8 meses, gerando assim o custo por veículo em 8 meses e 15.000 km simultaneamente.

Com isto é possível prever o custo de garantia por veículo que tenham atingido 8 meses de exposição e $15.000 \mathrm{~km}$ simultaneamente, tomando os valores da Tabela 3 e dividindo-os pelo fator 0.16 , como pode ser visto na Tabela 4 na página seguinte 
Tabela 4 - Custo de Garantia por Veículo para 8 Meses de Exposição no Campo e 15.000 km Corrigido.

\begin{tabular}{|l|c|c|c|}
\hline $\begin{array}{c}\text { Mês de } \\
\text { Produção }\end{array}$ & $\begin{array}{c}\text { CPV 8 meses } \\
\text { em Exposição } \\
\text { (UM\$) }\end{array}$ & $\begin{array}{c}\text { Fator de } \\
\text { Correlação }\end{array}$ & $\begin{array}{c}\text { CPV Corrigido } \\
\text { (UM\$) }\end{array}$ \\
\hline set/04 & $\mathbf{4 , 6 5}$ & 0,16 & 29,08 \\
\hline out/04 & $\mathbf{4 , 7 2}$ & 0,16 & 29,49 \\
\hline nov/04 & $\mathbf{5 , 5 3}$ & 0,16 & 34,55 \\
\hline dez/04 & $\mathbf{3 , 9 9}$ & 0,16 & 24,96 \\
\hline jan/05 & $\mathbf{8 , 0 5}$ & 0,16 & 50,33 \\
\hline fev/05 & $\mathbf{8 , 4 6}$ & 0,16 & 52,90 \\
\hline mar/05 & $\mathbf{6 , 3 2}$ & 0,16 & 39,50 \\
\hline abr/05 & $\mathbf{7 , 3 6}$ & 0,16 & 45,99 \\
\hline mai/05 & $\mathbf{6 , 1 7}$ & 0,16 & 38,57 \\
\hline jun/05 & $\mathbf{5 , 3 6}$ & 0,16 & 33,52 \\
\hline jul/05 & $\mathbf{5 , 8 1}$ & 0,16 & 36,30 \\
\hline ago/05 & $\mathbf{7 , 8 4}$ & 0,16 & 48,98 \\
\hline Média & $\mathbf{6 , 1 7}$ & $\mathbf{0 , 1 6}$ & $\mathbf{3 8 , 5 7}$ \\
\hline
\end{tabular}

Os valores obtidos na Tabela 4 são somados aos valores de custo de garantia em 12 meses exposição no campo da Tabela 2, para a obtenção dos valores do custo de garantia em 24 meses cujos resultados estão na Tabela 5:

Tabela 5 - Custo de Garantia por Veículo para 24 Meses de Exposição no Campo

\begin{tabular}{|l|c|c|c|}
\hline $\begin{array}{c}\text { Mês de } \\
\text { Produção }\end{array}$ & $\begin{array}{c}\text { CPV Corrigido } \\
\text { (UM\$) }\end{array}$ & $\begin{array}{c}\text { CPV 12 Meses } \\
\text { (UM\$) }\end{array}$ & $\begin{array}{c}\text { CPV 24 Meses } \\
\text { (UM\$) }\end{array}$ \\
\hline set/04 & 29,08 & 115,04 & 144,12 \\
\hline out/04 & 29,49 & 101,01 & 130,51 \\
\hline nov/04 & 34,55 & 121,01 & 155,56 \\
\hline dez/04 & 24,96 & 118,72 & 143,67 \\
\hline jan/05 & 50,33 & 124,00 & 174,32 \\
\hline fev/05 & 52,90 & 148,42 & 201,32 \\
\hline mar/05 & 39,50 & 122,58 & 162,08 \\
\hline abr/05 & 45,99 & 129,23 & 175,22 \\
\hline mai/05 & 38,57 & 122,74 & 161,31 \\
\hline jun/05 & 33,52 & 115,55 & 149,07 \\
\hline jul/05 & 36,30 & 127,61 & 163,91 \\
\hline ago/05 & 48,98 & 148,01 & 196,99 \\
\hline Média & 38,57 & 124,84 & 163,41 \\
\hline
\end{tabular}

Porém, para a determinação do custo por veículo em 36 meses de exposição é necessário definir a correlação entre 24 e 36 meses de exposição. A grande maioria das plataformas de veículos produzidos no mercado brasileiro é derivada de plataformas desenvolvidas originalmente para serem utilizadas no continente europeu. Com isto é possível utilizar os bancos de dados de falhas de campo das 
empresas no Reino Unido, onde o período de 36 meses de garantia é praticado regularmente. Estes dados mostram que o índice de reclamações por veiculo vendido aumenta em 32\%. Esta mesma observação é observada no mercado sulafricano, em torno de 31,5\%. Assim, considerando-se a pior condição de operação possível será utilizado o fator de correlação de 1,32 por mês de produção para a determinação do custo de garantia em 36 meses de exposição no mercado brasileiro. Os dados finais estão dispostos na Tabela 6 abaixo:

Tabela 6 - Custo de Garantia por Veículo para 36 Meses de Exposição no Campo

\begin{tabular}{|l|c|c|c|}
\hline $\begin{array}{c}\text { Mês de } \\
\text { Produção }\end{array}$ & $\begin{array}{c}\text { CPV 24 Meses } \\
\text { (UM\$) }\end{array}$ & $\begin{array}{c}\text { Fator de } \\
\text { Correlação }\end{array}$ & $\begin{array}{c}\text { CPV 36 Meses } \\
\text { (UM\$) }\end{array}$ \\
\hline set/04 & 144,12 & 1,32 & 190,24 \\
\hline out/04 & 130,51 & 1,32 & 172,27 \\
\hline nov/04 & 155,56 & 1,32 & 205,34 \\
\hline dez/04 & 143,67 & 1,32 & 189,65 \\
\hline jan/05 & 174,32 & 1,32 & 230,11 \\
\hline fev/05 & 201,32 & 1,32 & 265,74 \\
\hline mar/05 & 162,08 & 1,32 & 213,94 \\
\hline abr/05 & 175,22 & 1,32 & 231,29 \\
\hline mai/05 & 161,31 & 1,32 & 212,93 \\
\hline jun/05 & 149,07 & 1,32 & 196,77 \\
\hline jul/05 & 163,91 & 1,32 & 216,36 \\
\hline ago/05 & 196,99 & 1,32 & 260,03 \\
\hline Média & 163,41 & 1,32 & 215,70 \\
\hline
\end{tabular}

A partir da aplicação modelo pode-se verificar na Tabela 7 abaixo os valores dos custos de garantia por veículo dentro do período de 12, 24 e 36 meses respectivamente que deverão ser utilizados para tomada de decisão quanto a extensão do período de garantia em veículos populares: 
Tabela 7 - Custo de Garantia por Veículo para 12, 24 e 36 Meses de Exposição no Campo

\begin{tabular}{|l|c|c|c|}
\hline $\begin{array}{c}\text { Mês de } \\
\text { Produção }\end{array}$ & $\begin{array}{c}\text { CPV 12 Meses } \\
\text { (UM\$) }\end{array}$ & $\begin{array}{c}\text { CPV 24 Meses } \\
\text { (UM\$) }\end{array}$ & $\begin{array}{c}\text { CPV 36 Meses } \\
\text { (UM\$) }\end{array}$ \\
\hline set/04 & 115,04 & 144,12 & 190,24 \\
\hline out/04 & 101,01 & 130,51 & 172,27 \\
\hline nov/04 & 121,01 & 155,56 & 205,34 \\
\hline dez/04 & 118,72 & 143,67 & 189,65 \\
\hline jan/05 & 124,00 & 174,32 & 230,11 \\
\hline fev/05 & 148,42 & 201,32 & 265,74 \\
\hline mar/05 & 122,58 & 162,08 & 213,94 \\
\hline abr/05 & 129,23 & 175,22 & 231,29 \\
\hline mai/05 & 122,74 & 161,31 & 212,93 \\
\hline jun/05 & 115,55 & 149,07 & 196,77 \\
\hline jul/05 & 127,61 & 163,91 & 216,36 \\
\hline ago/05 & 148,01 & 196,99 & 260,03 \\
\hline Média & 124,84 & 163,41 & 215,70 \\
\hline
\end{tabular}

Finalmente, a Tabela 8 mostra resumidamente a seqüência de atividades descritas para a execução do modelo para a verificação quanto à extensão do período de garantia, com todos os seus respectivos dados de entrada e saída.

Tabela 8 - Fluxo de Atividades para Execução do Modelo para Extensão do Período de Garantia

\begin{tabular}{|c|c|c|c|c|}
\hline Atividade & Descrição & Dados de Entrada & Dados de Saída & Recursos Utilizados \\
\hline A & $\begin{array}{c}\text { Obtenção do custo de } \\
\text { garantia por veículo após } 12 \\
\text { meses de exposição }\end{array}$ & Dados de garantia & $\begin{array}{l}\text { Custo de garantia por veículo } \\
\text { após } 12 \text { meses de exposição }\end{array}$ & $\begin{array}{l}\text { Banco de dados de falhas } \\
\text { de campo }\end{array}$ \\
\hline B & $\begin{array}{c}\text { Obtenção do custo de } \\
\text { garantia por veículo após } 8 \\
\text { meses de exposição e } 15.000 \\
\text { km completados } \\
\end{array}$ & Dados de garantia & $\begin{array}{l}\text { Custo de garantia por veículo } \\
\text { após } 8 \text { meses de exposição e } \\
15.000 \mathrm{~km} \text { completados }\end{array}$ & $\begin{array}{l}\text { Banco de dados de falhas } \\
\text { de campo }\end{array}$ \\
\hline C & $\begin{array}{l}\text { Aplicação do fator } 0,16 \text { nos } \\
\text { dados de saída das } \\
\text { atividades A e B anteriores }\end{array}$ & $\begin{array}{l}\text { Custo de garantia por } \\
\text { veículo após } 12 \text { meses } \\
\text { de exposição + Custo de } \\
\text { garantia por veículo após } \\
8 \text { meses de exposição e } \\
15.000 \text { km completados }\end{array}$ & $\begin{array}{l}\text { Custo de garantia por veículo } \\
\text { convertido para } 8 \text { meses de } \\
\text { exposição e } 15.000 \mathrm{~km} \\
\text { completados. }\end{array}$ & $\begin{array}{l}\text { Fator obtido da pesquisa de } \\
\text { satisfação do cliente QAS }\end{array}$ \\
\hline D & $\begin{array}{c}\text { Soma do custo de garantia } \\
\text { por veículo convertido para } 8 \\
\text { meses de exposição e } 15.000 \\
\text { km obtido na atividade C } \\
\text { completados com o custo de } \\
\text { garantia por veículo após } 12 \\
\text { meses de exposição obtidos } \\
\text { na atividade A }\end{array}$ & $\begin{array}{l}\text { Custo de garantia por } \\
\text { veículo convertido para } 8 \\
\text { meses de exposição e } \\
15.000 \text { km completados } \\
\text { + Custo de garantia por } \\
\text { veículo após } 12 \text { meses } \\
\text { de exposição }\end{array}$ & $\begin{array}{l}\text { Custo projetado de garantia } \\
\text { por veículo após } 24 \text { meses de } \\
\text { exposição }\end{array}$ & $\begin{array}{l}\text { Banco de dados de falhas } \\
\text { de campo }\end{array}$ \\
\hline E & $\begin{array}{l}\text { Aplicação do fator } \mathrm{FC}=1,32 \\
\text { nos dados de saída da } \\
\text { atividade } \mathrm{D} \text { anterior }\end{array}$ & $\begin{array}{l}\text { Custo projetado de } \\
\text { garantia por veículo após } \\
24 \text { meses de exposição }\end{array}$ & $\begin{array}{l}\text { Custo projetado de garantia } \\
\text { por veículo após } 36 \text { meses de } \\
\text { exposição }\end{array}$ & $\begin{array}{l}\text { Dados de reclamações de } \\
\text { campo no Reino Unido e } \\
\text { Africa do Sul }\end{array}$ \\
\hline
\end{tabular}




\subsection{Análise Crítica do Método para Cálculo do Custo de Garantia Após 36 Meses de Exposição no Campo}

Ao iniciar a análise crítica do modelo para determinação do custo em garantia por veículo em 36 meses de exposição no campo, deve-se assumir que o maior risco assumido, é quanto à utilização do fator de conversão 1,32, utilizado pelos fabricantes do Reino Unido para a conversão dos dados de garantia de 24 para 36 meses de exposição. O que deve ser considerado neste estudo é que as condições de operação dos veículos no continente europeu são muito diferentes quando comparadas às condições de operação dentro do território brasileiro, em que as condições de pavimento, trânsito urbano e temperatura entre outros fatores, podem influenciar quanto ao desempenho e durabilidade de componentes e sistemas veiculares.

Com isto é necessário realizar uma simulação do custo de garantia por veículo, considerando diferentes fatores de conversão, obtendo os respectivos custos médios de garantia por veículo simulados de acordo com a utilização de cada fator de conversão utilizado, para que seja possível ter mais dados no processo de tomada de decisão por parte da empresa. Esta simulação foi realizada, gerando os valores que estão dispostos na Figura 13: 


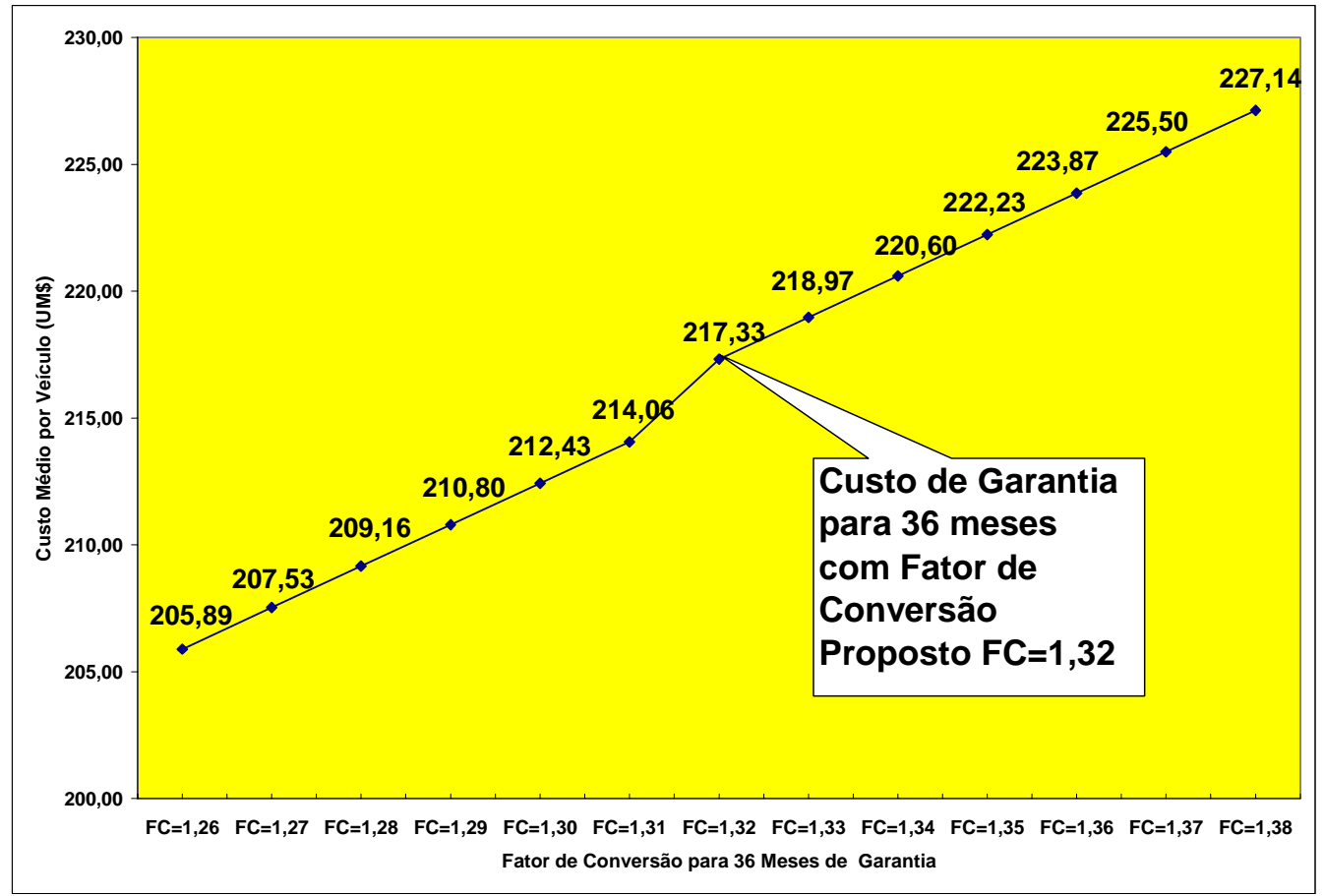

Figura 13 - Custo de Garantia x Fator de Conversão

O modelo proposto apresenta alguns riscos e desvantagens. A principal desvantagem refere-se ao fato de que não existem dados reais provenientes do banco de dados de garantia dos concessionários quanto ao tamanho da amostra de veículos que tenham atingido 15.000 km e 8 meses em exposição no campo, que representa 8 meses em exposição, o que acarretou na utilização do fator 0,16, decorrente do tamanho de amostra de clientes que são entrevistados em uma pesquisa de satisfação de clientes, cujos veículos já tenham completado a quilometragem mínima de $5.600 \mathrm{~km}$ em 3 meses de exposição no campo, que através de uma simples regra matemática gera a proporção de veículos produzidos que completarão uma quilometragem mínima de 15.000 km em 8 meses de exposição no campo.

O modelo proposto considera somente os componentes que venham a falhar dentro do período atual de garantia estipulado pelo fabricante, que é de 12 meses, o que aumenta o risco de não se conhecer todos os componentes e os respectivos modos de falha que venham a ocorrer no período de exposição no campo entre 13 e 36 meses. Isto significa que os componentes que falharão após 36 meses de exposição no campo necessariamente não serão os mesmos que falham dentro do 12 meses 
de garantia atualmente cobertos pela montadora. O mesmo deve-se aplicar ao modo de falha dos componentes, inclusive em função do maior tempo de exposição no campo, em que eventualmente os modos de falha podem ser completamente diferentes.

Porém, mesmo com as dificuldades mencionadas anteriormente, uma visualização de quais componentes do veículo teriam o maior impacto neste custo previsto mostra-se necessária, como na tabela 9 abaixo:

Tabela 9 - Dez Maiores Reclamações por Custo

\begin{tabular}{|r|l|l|r|}
\hline $\begin{array}{c}\text { SEQ. } \\
\text { CUSTO }\end{array}$ & $\begin{array}{l}\text { CODIGO } \\
\text { M.OBRA }\end{array}$ & \multicolumn{1}{|c|}{ DESCRICAO } & QTDE \\
\hline 1 & L2085 & JTA.TUBO DT.ESCAPAM. & 1189 \\
\hline 2 & J1308 & EMBOLO-BIELAIANEIS & 79 \\
\hline 3 & K0700 & ROLAMENTO EMBREAGEM & 267 \\
\hline 4 & L2584 & SILENC.CTRL.ESCAP.UN & 219 \\
\hline 5 & E3437 & SUPORTE TINANTE AL & 146 \\
\hline 6 & $\mathrm{J4} 4640$ & MOTOR PARTIDA - SUBS & 91 \\
\hline 7 & $J 0518$ & CABECOTE-MOTOR & 17 \\
\hline 8 & R3260 & ESP.RETR.EXT.MAN.LD & 109 \\
\hline 9 & L2160 & TUBO ESC.DT.(COL.AO & 40 \\
\hline 10 & $\mathrm{J4100}$ & ALTERNADOR CJT. & 24 \\
\hline
\end{tabular}

Somente com estas informações disponíveis será possível que os departamentos da empresa diretamente envolvidos com a qualidade do produto serão capazes de tomar decisões quanto as seguintes possíveis ações de melhoria, dependendo do modo de falha destes componentes, para a extensão do período de garantia:

- Mudança de especificações de projeto;

- Mudança no processo de validação do produto;

- Mudança no processo de montagem dos componentes;

- Melhorias no processo de fabricação nos fornecedores;

- Mudanças no processo de inspeção no recebimento de componentes.

Com posse destas informações, torna-se possível o acesso a estes componentes por parte dos departamentos envolvidos para a análise, pois estas peças servirão de referência para o conhecimento dos possíveis modos de falha quando submetidas a 
uma solicitação agravada, o que poderá proporcionar uma determinação mais segura das melhorias necessárias para que se tenha a extensão do período de garantia do veículo.

O modelo proposto apresenta como vantagem principal o fato de utilizar os dados de garantia dos veículos que já tenham sido expostos no campo como referência, o que proporciona o real conhecimento da performance do produto e a voz do cliente em geral. Outro ponto importante é a possibilidade de a qualquer momento, com a utilização dos dados de falhas de campo, exercitar este modelo e compará-lo com o valor atual do custo do veículo destinado a garantia por veículo como demonstrado na Figura 13.

É necessário ressaltar que a tomada de decisão depende única e exclusivamente da estratégia da empresa quanto às suas políticas de marketing e financeira, que necessitam da análise de valores e dados extremamente confidenciais que não podem ser divulgados neste estudo. Entretanto a utilização deste modelo é uma ferramenta para a tomada de decisão quanto a extensão ou não do período do garantia para veículos populares atendendo ao objetivo deste estudo proposto. 


\section{PROPOSTA DE IMPLEMENTAÇÃO DA EXTENSÃO DO PERÍODO DE GARANTIA PARA VEÍCULOS POPULARES}

Em função da análise crítica do método para cálculo do custo de garantia em 36 meses de exposição no campo e este derivar de uma seqüência de suposições de alto risco, torna-se necessária a aplicação de uma proposta de um plano de implementação da extensão do período de garantia em veículos populares, caso esta venha a ser adotada pela empresa.

A proposta será dividida de acordo com os quesitos técnicos pertinentes, assim como de acordo com as diversas possibilidades que estes quesitos permitem, o que proporcionará uma análise crítica quanto às vantagens e desvantagens de cada uma das propostas.

Finalmente após a análise crítica de cada uma das opções para a validação técnica da extensão do período de garantia para veículos populares, será proposto um plano para a implementação desta na empresa e no mercado para os clientes.

\subsection{Plano de Validação Técnica da Extensão do Período de Garantia para Veículos Populares}

A proposta para reduzir a incerteza proporcionada pelo modelo proposto, é monitorar o comportamento de alguns veículos populares produzidos pela empresa com o propósito de verificar o funcionamento de todos os componentes que possam falhar no prazo de 36 meses e que possam comprometer os objetivos financeiros e de mercado da empresa quanto à extensão de garantia em veículos populares. 


\subsubsection{Determinação do Tamanho de Amostra dos Veículos Monitorados}

Para o sucesso do plano de validação de garantia estendida será necessária a determinação do tamanho da amostra de veículos que serão monitorados. Neste trabalho será utilizada a teoria de inferência estatística para a tomada de decisão quanto à determinação do tamanho de amostra.

Segundo Brush (1988) é possível obter conclusões de uma população de que um pequeno tamanho de amostra faz parte. Porém, a suposição de que as observações são independentes é crítica e sempre deve ser verificada, pois há dois tipos de erros que podem ocorrer nestas situações: Erros devido a parcialidade e erros devidos a amostragem.

Erros devidos a parcialidade ocorrem porque os experimentos ou testes não refletem exatamente as condições de campo que a população operará. Pode-se considerar nesta categoria de erros, o exemplo de peças que são validadas em laboratório em condições que nem sempre podem ser controladas pelos clientes.

Erros devido a amostragem podem ocorrer porque os itens da amostra raramente refletem exatamente as características de uma população inteira. Erros devido a amostragem podem ser controlados especificando, com antecedência, o número de unidades a serem consideradas no teste ou experimento.

Para o plano de validação da extensão da garantia para veículos populares, diante da impossibilidade de realizar medições variáveis nos veículos que estarão retornando aos concessionários para realização da verificação dos seus componentes, será utilizado o sistema de medição por atributo onde somente as respostas "defeituosa" e "não defeituosa" poderão ser aceitas como respostas quanto à inspeção de sistemas e seus respectivos componentes.

Brush (1998) afirma que a experiência com uma grande proporção de inferências estatísticas, requer que os técnicos lidem com três situações paramétricas: 
- Proporções (Exemplos: percentual defeituoso, percentual com falhas na inspeção, etc.) Neste caso, a distribuição mais apropriada é a distribuição binomial para determinação do tamanho de amostra;

- Taxas (Exemplos: Falhas por hora, defeitos por 100 unidades). Neste caso a distribuição de Poisson é a mais apropriada para determinação do tamanho de amostra, assumindo o formato de contagem e medições da exposição das taxas de falha;

- Média e/ou variância de uma distribuição contínua. Uma distribuição normal é considerada a mais apropriada. O número de unidades e "leitura" ou "medição" das falhas devem ser as informações consideradas ao utilizar estes parâmetros.

Segundo LaMothe (2002), nas condições em que o plano de validação da extensão de garantia requer, o teste de probabilidade binomial é o mais adequado, pois um sistema de medição por variável não está disponível e um teste precisa ser realizado para entender se um método proposto é melhor que o atual, podendo ser aplicado a peças e processos.

Este teste define quantas amostras devem ser observadas ( $n$ ) a certo nível de risco ou probabilidade de aceitação $\left(P_{a}\right)$, em uma população com $c$ ou menor número de falhas, baseados em uma taxa de falhas conhecida $(p)$, ou a proporção da população que apresenta defeitos.

As regras para realizar um teste seguindo a probabilidade binomial, já utilizando o mesmo para o presente estudo são:

- Escolher um nível de confiança e determinar $P_{a}$. É importante lembrar que $P_{a}$ = 1 - nível de confiança. Na indústria automotiva usualmente utiliza-se 95\% de confiança. Portanto $P_{a}=1-0,95=0,05$;

- Determinar o número de falhas, $c$, que são toleráveis; Será tolerado $c=2$ componentes com substituição/reparo por veículo por inspeção;

- Calcular a taxa de falha atual, $p$, baseada no número de falhas e produção total. Como estes dados de IPTV são confidenciais será utilizado para 
simulação o dado 50 IPTV, que correspondem a 5 pph, consequentemente $p$ $=0,05$

- Usar a Tabela 10 para determinar o tamanho da amostra, $n$, baseado no risco assumido, número de falhas, e taxa de falhas conhecida. Cruzando os dados dos passos anteriores na Tabela, o tamanho de amostra para a validação da extensão do período de garantia para veículos populares é de no mínimo 117 veículos;

Tabela 10 - Número de Amostras por Probabilidade Binomial (La Mothe, 2002)

\begin{tabular}{|c|ccc|ccc|ccc|}
\cline { 2 - 9 } \multicolumn{1}{c|}{} & \multicolumn{3}{c|}{$c=0$} & \multicolumn{3}{c|}{$c=1$} & \multicolumn{3}{c|}{$c=2$} \\
\hline$P_{A}$ & 0,01 & 0,05 & 0,1 & 0,01 & 0,05 & 0,1 & 0,01 & 0,05 & 0,1 \\
\hline $0.01^{*}$ & 461 & 300 & 231 & 648 & 450 & 358 & 810 & 583 & 471 \\
$0.05^{*}$ & 93 & 60 & 47 & 130 & 90 & 72 & 162 & 117 & 94 \\
0,1 & 44 & 29 & 22 & 63 & 44 & 35 & 78 & 57 & 47 \\
0,2 & 21 & 14 & 11 & 30 & 21 & 17 & 38 & 28 & 23 \\
0,3 & 13 & 9 & 7 & 19 & 14 & 11 & 24 & 18 & 15 \\
0,4 & 10 & 6 & 5 & 14 & 10 & 8 & 18 & 13 & 11 \\
\hline
\end{tabular}

- Depois da determinação do tamanho de amostra deve-se executar o plano, verificando-se se o numero de falhas por inspeção é menor ou igual ao número predeterminado de falhas.

\subsubsection{Intervalo para a Inspeção Periódica dos Veículos Monitorados}

Segundo dados da Gipa (2006), o motorista brasileiro percorre com o carro em média $12.800 \mathrm{~km}$ em um ano. Com base nestes dados, a recomendação para o plano de validação é de que os veículos monitorados sejam inspecionados a cada 6 meses ou $6.500 \mathrm{~km}$, o que ocorrer antes para a verificação dos seus componentes e sistemas. 


\subsubsection{Definição de Itens a Serem Verificados nas Inspeções Periódicas}

O plano de verificação de componentes nas inspeções periódicas, que está contida no Anexo 1 deste trabalho, deverá cobrir os seguintes subsistemas dos veículos a serem verificados:

- Motor e transmissão;

- Freios;

- Direção, suspensões (dianteira e traseira) e pneus;

- Carroçaria;

- Sistema elétrico.

\subsubsection{Origem dos Veículos Inspecionados}

É necessário neste estudo determinar a origem dos veículos da amostra que serão inspecionados no plano de validação da extensão do período de garantia para veículos populares.

As diversas alternativas serão analisadas de acordo com as suas vantagens e desvantagens, viabilidade financeira, tempo de execução, assim como a facilidades e limitações para disponibilização de recursos técnicos e de pessoal qualificado.

\subsubsection{Utilização de Veículos Provenientes do Campo de Provas da Empresa}

A empresa possui um grande campo de provas para desenvolvimento e validação de novos produtos que serão lançados no mercado brasileiro e os mais diversos mercados de exportação. 
Este campo de provas possui diversos tipos de pistas que simulam as condições de terreno em que os veículos são utilizados pelos clientes, assim como laboratórios de testes que permitem a análise de todos os componentes do veículo quanto ao seu desempenho, qualidade e durabilidade.

Para este plano de validação, a estimativa é de que cada veículo percorra no campo de provas aproximadamente $8.000 \mathrm{~km}$ por mês, ao assumir que cada veículo percorra $500 \mathrm{~km}$ por dia nas pistas do campo de provas durante quatro dias por semana, e que o mesmo pare um dia por semana para manutenção. Assim torna-se possível simular a quilometragem média anual percorrida pelo motorista brasileiro em apenas dois meses. Portanto, seriam necessários seis meses para a simulação da quilometragem média percorrida em três anos pelo motorista brasileiro e que será utilizada como referência para a validação da extensão do período de garantia em veículos populares.

As principais vantagens da utilização dos veículos provenientes do campo de provas da empresa são:

- Curto período de tempo para validação do plano;

- Constante monitoramento dos veículos da amostra;

- Utilização de técnicos treinados para a avaliação e detecção de problemas;

- Proximidade física estratégica com todos os departamentos da empresa, inclusive fornecedores de componentes;

- Controle efetivo do plano de manutenção dos veículos monitorados;

- Possibilidade de utilização de veículos com o mais recente conteúdo técnico;

- Certeza de que toda a amostra será inspecionada.

As principais desvantagens da utilização do campo de provas da empresa são:

- A ausência do cliente final para retroalimentar as suas impressões quanto ao desempenho do produto;

- As pistas podem não refletir todos os tipos de terreno encontrados no território nacional; 
- O campo de provas não permite reproduzir todas as condições climáticas do país;

- O número elevado de amostras ocupará em demasia as pistas do complexo, assim como o número de técnicos que serão designados a dirigir os veículos, prejudicando assim outros programas e atividades propostas;

- O custo elevado para a disponibilização e manutenção das amostras.

\subsubsection{Utilização de Veículos Provenientes da Frota da Empresa}

A empresa possui uma grande frota de veículos para suporte aos seus diversos departamentos e disponibilização a jornalistas especializados para avaliação, e que poderiam ser utilizados dentro da amostragem necessária para a execução do plano de validação de extensão do período de garantia.

A manutenção destes veículos é realizada pelo Centro Técnico de Serviços, que exerce o papel de uma concessionária localizada dentro da própria empresa, o que permite um constante monitoramento dos veículos, assim como os percursos que serão adotados pelos seus condutores.

Não é possível estimar a quilometragem que cada veículo percorrerá neste caso, tampouco saber se será possível simular a quilometragem média anual percorrida pelo motorista brasileiro. Assim, existe um alto risco em determinar o tempo que será necessário para completar o plano de validação de extensão da garantia em veículos populares, utilizando veículos da frota da empresa.

Este alto risco pode ser amenizado através de iniciativas da empresa que incentivem os funcionários a utilizarem os veículos por longas distâncias, como por exemplo, a realização de um leilão de quilometragem entre os funcionários, disponibilizando unidades para aqueles que se oferecerem a percorrer maiores distâncias em finais de semana e períodos de férias. 
As principais vantagens da utilização de veículos provenientes da frota da empresa são:

- Constante monitoramento dos veículos da amostra;

- Utilização de funcionários e jornalistas técnicos habituados a avaliar a qualidade de veículos;

- Proximidade física estratégica com todos os departamentos da empresa, inclusive fornecedores de componentes;

- Controle efetivo do plano de manutenção dos veículos monitorados;

- Possibilidade de utilização de veículos com o mais recente conteúdo técnico;

- Certeza de que toda a amostra será inspecionada.

As principais desvantagens da utilização de veículos provenientes da frota da empresa são:

- A ausência do cliente final para retroalimentar as suas impressões quanto ao desempenho do produto;

- Os percursos que os condutores percorrerão podem não caracterizar todas as condições de tipos de terreno e condições climáticas encontrados no território nacional;

- O número elevado de amostras a serem incorporadas na frota da empresa;

- O custo elevado para a disponibilização e manutenção das amostras.

- Incerteza quanto à duração do período para execução do plano de validação.

\subsubsection{Utilização de Veículos Provenientes de Frotas de Outras Empresas}

Poderão ser utilizados veículos populares provenientes de frotas de outras empresas, que com base no histórico de revisões periódicas nos concessionários, possuam o perfil necessário de alta quilometragem em um curto espaço de tempo, para que contribuam com o plano de validação da extensão de garantia para veículos populares. 
Neste plano, os veículos seriam inspecionados de acordo com os intervalos propostos no item 5.1.2 deste trabalho, com visita pré-agendada aos concessionários da marca, cujos funcionários passariam por um treinamento técnico e de conscientização quanto ao plano de validação da extensão do período de garantia para veículos populares.

Para garantir que os clientes escolhidos para participarem da validação do modelo de extensão de garantia em veículos populares, será necessário oferecer uma série de incentivos para que estes clientes compareçam à rede de concessionários da montadora, garantindo assim que os veículos sejam inspecionados quanto ao plano de verificação. Algumas sugestões que podem ser colocadas em prática sem acarretar em um alto investimento para a montadora:

- Instalação gratuita de acessórios em geral;

- Troca gratuita de óleo e filtros;

- Alinhamento e balanceamento gratuito;

- Lavagem completa;

- Disponibilização gratuita de guincho 24 horas por dia;

- Seguro gratuito dentro do período de garantia;

- Acesso gratuito a eventos patrocinados pela empresa;

- Empréstimo de veículo da empresa em finais de semana;

- Viagens;

- Incentivos financeiros para compra de veículos no futuro (descontos no preço final, taxas de juros mais atraentes, maiores prazos para pagamento, etc.).

Porém não é possível estimar a quilometragem que cada veículo percorrerá neste caso, gerando uma grande incerteza quanto à viabilidade de simulação da quilometragem média anual percorrida pelo motorista brasileiro para toda a população da amostra. Portanto, há um alto risco em determinar o tempo que será necessário para completar o plano de validação de extensão da garantia em veículos populares utilizando-se de veículos de frotas de outras empresas.

As principais vantagens da utilização de veículos de frotas de outras empresas são: 
- Baixo custo para a inspeção periódica das amostras;

- Os motoristas representarão os clientes finais, o que permitirá a retroalimentação com a qualidade de informação esperada quanto ao desempenho do produto no campo;

- Possibilidade de utilização de veículos com o mais recente conteúdo técnico.

As principais desvantagens da utilização de veículos de frotas de outras empresas são:

- A incerteza de que toda a amostra de veículos será inspecionada;

- Necessidade de contato permanente com as empresas para a verificação de que os veículos não excedam os intervalos para a inspeção periódica;

- Os veículos das empresas podem não estar localizados em todas as regiões do país, o que pode descaracterizar as condições de terreno e climáticas encontradas no território nacional;

- Incerteza quanto à duração do período para execução do plano de validação.

\subsubsection{Utilização de Veículos Provenientes de Frotas de Empresas Locadoras de Veículos}

Poderão ser utilizados veículos populares provenientes de frotas de empresas locadoras de veículos que tenham filiais em todo o território nacional, que reconhecidamente possuem o perfil necessário de alta quilometragem em um curto espaço de tempo, para contribuírem com o plano de validação da extensão de garantia para veículos populares.

Neste plano, os veículos seriam inspecionados de acordo com os intervalos propostos no item 5.1.2 deste trabalho, com visita pré-agendada aos concessionários da montadora, cujos funcionários passariam por um treinamento técnico e de conscientização quanto ao plano de validação da extensão do período de garantia para veículos populares. 
Mesmo com a certeza de que estes veículos percorram altas distâncias, não é possível determinar um prazo exato de quando as amostras percorreriam a distância necessária, assim como também não é possível afirmar que o número total de amostras necessárias cumpra com os requerimentos necessários do plano de validação. Portanto há um alto risco em utilizar estes veículos de empresas locadoras de veículos como amostras para a validação de extensão da garantia em veículos populares utilizando-se de veículos de frotas de empresas locadoras de veículos.

As principais vantagens da utilização de veículos de frotas de empresas locadoras de veículos são:

- Baixo custo para a inspeção periódica das amostras;

- Possibilidade de utilização de veículos com o mais recente conteúdo técnico;

- Os veículos circularão por todo o território nacional, o que possibilitará a verificação do produto quanto à exposição a todos os tipos de terreno e condições climáticas do país.

As principais desvantagens da utilização de veículos de frotas de empresas locadoras de veículos são:

- A incerteza de que toda a amostra de veículos será inspecionada;

- Necessidade de contato permanente com as empresas locadoras de veículos para a verificação de que os produtos não excedam os intervalos para a inspeção periódica, visto que estes limites podem ser ultrapassados quando os veículos estiverem sendo utilizados por seus clientes;

- As empresas locadoras de veículos não representarão os clientes finais, o que não permitirá a retroalimentação com a qualidade de informação esperada quanto ao desempenho do produto no campo;

- Incerteza quanto ao tempo de execução do plano de validação. 


\subsubsection{Utilização de Veículos de Motoristas de Praça}

Outra opção para a origem da amostra de veículos a serem inspecionados é o monitoramento de veículos utilizados por motoristas de praça. Estes veículos também possuem o perfil necessário de alta quilometragem percorrida em um curto espaço de tempo, de franca contribuição para com o plano de validação da extensão de garantia para veículos populares.

Neste plano, os veículos seriam inspecionados de acordo com os intervalos propostos no item 5.1.2 deste trabalho, com visita pré-agendada aos concessionários da montadora, cujos funcionários passariam por um treinamento técnico e de conscientização quanto ao plano de validação da extensão do período de garantia para veículos populares.

Assim a empresa contará com o auxílio dos motoristas de praça, que poderão contar com os mesmos benefícios descritos no item 5.1.4.3, como incentivos para que visitem os concessionários para a inspeção periódica.

Mesmo com a certeza de que estes veículos percorrerão grandes distâncias, não é possível determinar um prazo exato de quanto tempo será necessário para que as amostras percorram a distância determinada assim como também não é possível afirmar que o número total de amostras necessárias cumpra com os requerimentos necessários do plano de validação. Portanto há um alto risco em utilizar os veículos de motoristas de praça como amostras para a validação de extensão da garantia em veículos populares.

As principais vantagens do monitoramento de veículos utilizados por motoristas de praça são:

- Baixo custo para a inspeção periódica das amostras;

- Possibilidade de utilização de veículos com o mais recente conteúdo técnico; 
- Os veículos circularão por todo o território nacional, o que possibilitará a verificação do produto quanto à exposição a todos os tipos de terreno e condições climáticas do país;

- Os motoristas de praça representam a opinião dos clientes finais.

As principais desvantagens do monitoramento de veículos utilizados por motoristas de praça são:

- A incerteza de que toda a amostra de veículos será inspecionada;

- Necessidade de contato permanente com os motoristas de praça, para que não deixem de comparecer às inspeções periódicas nos concessionários;

- Incerteza de que os motoristas de praça cumpram com o plano de manutenção preventiva de seus veículos nos concessionários;

- Incerteza quanto ao tempo de execução do plano de validação.

\subsubsection{Utilização de Veículos de Clientes da Empresa}

A última opção para a origem da amostra de veículos a serem inspecionados é a de veículos utilizados por clientes da empresa. Neste plano, os veículos seriam inspecionados de acordo com o intervalo proposto no item 5.1.2 deste trabalho, com visita pré-agendada nos concessionários da marca, cujos funcionários passariam por um treinamento técnico e de conscientização quanto ao plano de validação da extensão do período de garantia para veículos populares.

Serão utilizados para esta opção, como amostra para a validação do plano de garantia estendida, somente veículos produzidos no período entre setembro de 2004 e agosto de 2005, de acordo com o modelo proposto para a determinação do custo de garantia em 36 meses de exposição no campo, detalhado no item 4.2, e cujos proprietários tenham comprovadamente como habito a procura à rede de concessionários da montadora para manutenção preventiva de seus veículos. Estes veículos devem também nunca ter sido atendidos em oficinas mecânicas 
independentes, situação esta que pode desconfigurar as condições ideais de manutenção destes veículos.

Assim a empresa contará com o auxílio dos seus clientes em todo o território nacional, que poderão contar com os mesmos benefícios descritos no item 5.1.4.3 deste trabalho, como incentivos para que visitem os concessionários para a inspeção periódica.

A utilização de veículos de clientes da empresa apresenta alguns riscos quanto à possibilidade de incertezas na veracidade das respostas dos clientes quando questionados a respeito da disciplina requerida na manutenção dos veículos em concessionários da empresa antes da introdução do plano e durante todo o período em que este estiver sendo aplicado. Também não é possível determinar um prazo exato de quanto tempo será necessário para que as amostras percorram a distância pré-determinada assim como também não é possível afirmar que o número total de amostras cumpra com os requerimentos necessários do plano de validação. Portanto, o risco é grande ao utilizar veículos de empresas clientes da empresa como amostras para a validação de extensão da garantia.

As principais vantagens do monitoramento de veículos utilizados por clientes são:

- Baixo custo para a inspeção periódica das amostras;

- Os veículos circularão por todo o território nacional, o que possibilitará a verificação do produto quanto à exposição a todos os tipos de terreno e condições climáticas do país;

- Possibilidade de retroalimentação dos clientes finais.

As principais desvantagens do monitoramento de veículos utilizados por clientes são:

- A incerteza de que toda a amostra de veículos será inspecionada;

- Necessidade de contato permanente com os clientes para a verificação de que os produtos não excedam os intervalos para a inspeção periódica; 
- Os veículos dos clientes podem não estar localizados em todas as regiões do país, o que pode descaracterizar as condições de tipos de terreno e condições climáticas encontrados no território nacional;

- O tempo para a simulação dos 36 meses de exposição pode ser excessivo, o que pode ser um fator de risco determinante para a implementação da garantia estendida;

- Incerteza quanto à disponibilidade da amostra de veículos que atendam aos requerimentos necessários para o plano;

- Os veículos da amostra podem não refletir o mais recente conteúdo técnico do produto, que passa por modificações e por processo de melhoria contínua através do tempo;

- Incerteza quanto ao tempo de execução do plano de validação.

\subsection{Análise Crítica do Plano de Validação Técnica da Extensão do Período de Garantia para Veículos Populares}

Existem diversas alternativas para a execução do plano de validação da extensão do período de garantia em veículos populares, de acordo com o grande número de possibilidades quanto à determinação da origem dos veículos a serem monitorados no plano de validação da extensão do período de garantia para veículos populares. Portanto torna-se necessária uma análise critica de cada uma das alternativas estudadas.

O plano de validação da extensão de garantia para veículos populares necessita de alta confiabilidade nas informações colhidas das amostras que serão analisadas. Por este motivo, as opções de monitoramento de veículos que sejam utilizados por frotas de outras empresas, frotas de empresas locadoras de veículos e motoristas de praça tornam-se inapropriadas mesmo considerando o baixo investimento necessário e a possibilidade de ouvir a voz do cliente final para colocar em pratica o plano de validação da extensão da garantia ao escolher qualquer uma destas opções. 
A utilização de veículos de clientes da empresa demonstra ser uma alternativa interessante quando considerada a possibilidade das amostras representarem uma população de veículos que estarão distribuídos em todo o território nacional e que representarão à voz do cliente final. Porem, os riscos são grandes quanto à possibilidade de incertezas quanto à veracidade das respostas dos clientes quando questionados a respeito da disciplina requerida na manutenção dos veículos em concessionários da empresa antes da introdução do plano e durante todo o período em que este estiver sendo aplicado.

O uso de veículos da frota da empresa apresenta as vantagens da utilização de veículos com o mais recente conteúdo técnico e também pelo fato, por serem utilizados por funcionários e jornalistas especializados em avaliação de veículos. Porém, o alto investimento para a manutenção das amostras e o pagamento de mão de obra de funcionários mostra-se necessário para que seja garantida a confiabilidade nos resultados finais deste plano de validação. Outro ponto crítico a ser considerando nesta opção é a incerteza quanto ao tempo necessário para a execução do plano de validação.

A utilização de veículos do campo de provas da empresa surge como a alternativa mais viável para a execução do plano de validação da extensão de garantia para veículos populares por representar o maior controle sobre as amostras no tocante ao conteúdo técnico dos veículos, controle de manutenção, proximidade física com os demais departamentos da empresa e fornecedores, e principalmente, o controle efetivo da quilometragem percorrida pelas amostras no curto período estimado de seis meses para a total execução deste plano. O baixo nível de incerteza aliada às vantagens técnicas são superiores às desvantagens observadas nesta opção, mesmo quando consideradas as de nível econômico.

Eventualmente, outras opções podem ser adotadas para amenizar o impacto na utilização dos recursos técnicos e de pessoal envolvidos no campo de provas e que estejam associados a este plano de validação. Uma alternativa é estipular que cinqüenta por cento da amostra de veículos sejam monitorados no campo de provas da empresa e que os cinqüenta por cento restantes da amostra sejam de veículos provenientes da frota da empresa como já mencionado anteriormente. Nesta opção, 
embora os custos sejam menores, o grau de incerteza quanto ao plano de validação aumenta, provocando assim a vulnerabilidade do processo como um todo, certificando assim que a utilização de veículos do campo de provas da empresa é a única alternativa tecnicamente viável e de baixo risco para o plano de validação da extensão de garantia para veículos populares.

\subsection{Plano de Implementação da Extensão do Período de Garantia para Veículos Populares}

Após a execução do plano de validação técnica e posterior tomada de decisão quanto a extensão do período de garantia para veículos populares considerando-se que o número total de amostras dos veículos provenientes do campo de provas sejam aprovadas quanto à confiabilidade e durabilidade de seus componentes, é necessária a determinação de um plano de implementação por parte da empresa.

Recomenda-se a implementação progressiva da extensão do período de garantia em função do alto risco verificado neste plano, sendo este dividido em quatro fases. Portanto o plano de implementação da extensão do período de garantia para veículos populares contempla primeiramente dois anos de vigência e ao término deste período será analisada a viabilidade da adoção de três anos de acordo com os resultados obtidos.

\subsubsection{Primeira Fase - Comunicação e Treinamento}

A primeira fase do plano de implementação da extensão da garantia para veículos populares contempla as atividades de comunicação e treinamento de funcionários da

empresa, fornecedores e concessionários, assim como a divulgação da extensão da garantia junto aos clientes. 


\subsubsection{Comunicação e Treinamento dos Funcionários da Empresa}

A empresa deve comunicar os seus funcionários para que estes estejam informados quanto a decisão da empresa em ampliar o período de garantia para veículos populares como vantagem competitiva de mercado e também para manter a imagem de qualidade e robustez dos seus produtos junto aos seus clientes.

Esta comunicação deve ocorrer por ferramentas de informação visual como a colocação de faixas e cartazes nas portarias e corredores dos prédios, restaurantes e auditórios. É recomendada também a comunicação via intranet e folhetos explicativos a serem entregues para cada funcionário, explicando a importância do seu empenho no trabalho e no resultado esperado quanto à qualidade do produto.

O prazo estimado para a duração desta atividade é de aproximadamente um mês, desde o início da campanha, que prevê a instalação de faixas e cartazes na empresa até a entrega dos folhetos explicativos aos funcionários.

\subsubsection{Comunicação aos Fornecedores}

A empresa deve comunicar os fornecedores dos componentes quanto à extensão do período de garantia para veículos populares mesmo que eles tenham participado de todo o plano de validação técnica.

Esta comunicação deve ocorrer através de palestras lideradas pelos gerentes de qualidade em que os representantes dos fornecedores estejam presentes e informados quanto à sua responsabilidade em entregar peças de qualidade assegurada e que resistam aos três anos de garantia proposta.

O prazo estimado para a duração desta atividade é de aproximadamente um mês, desde o convite aos fornecedores até a realização das palestras na empresa. 


\subsubsection{Comunicação para os Concessionários}

A empresa deve comunicar os seus concessionários em todo o território nacional para que estes estejam informados quanto à decisão da empresa em ampliar o período de garantia para veículos populares como vantagem competitiva de mercado e também para manter a imagem de qualidade e robustez dos seus produtos junto aos seus clientes.

Os gerentes de vendas regionais da empresa distribuídos em todo o país reunirão os representantes dos concessionários para a comunicação do plano e como este deve ser seguido pelos concessionários.

O prazo estimado para a duração desta atividade é de aproximadamente um mês, desde o convite aos concessionários até a realização das palestras.

\subsubsection{Treinamento para os Funcionários dos Concessionários}

É necessário o treinamento de todos os funcionários dos concessionários que estejam envolvidos com a atividade de venda e manutenção de veículos populares.

Os vendedores devem ser treinados para que mostrem ao cliente as vantagens de adquirir um produto cuja qualidade e robustez sejam traduzidas em um período maior de garantia.

Os gerentes de vendas regionais da empresa distribuídos em todo o país reunirão os vendedores de todos os concessionários para o treinamento destes através de palestras.

O prazo estimado para a duração desta atividade é de aproximadamente um mês, desde o convite aos vendedores até a realização das palestras. 
Os funcionários envolvidos com a manutenção e reparo dos veículos serão treinados com o objetivo de que todos os procedimentos técnicos e administrativos de garantia sejam assegurados, desde a identificação dos veículos que possuem a garantia estendida até o envio das peças falhadas para análise do fabricante.

Este treinamento ocorrerá através de treinamentos interativos através da internet, já disponíveis atualmente para outras aplicações, em que os funcionários conseguem os seus créditos após terem acesso ao conteúdo teórico dos materiais e no final são submetidos a testes para verificação do conhecimento adquirido.

Os funcionários teriam aproximadamente o tempo limite de dois meses para a realização deste treinamento, sendo a sua certificação controlada pelo departamento de pós-vendas da empresa responsável pela administração e treinamento dos concessionários.

\subsubsection{Divulgação e Exposição na Mídia}

Após a comunicação e treinamento de todos os funcionários da empresa e certificada da prontidão de ambas as partes para o início da vigência da garantia estendida para veículos populares a empresa deve divulgar ao público que os seus produtos terão um período maior de garantia.

O departamento de marketing da empresa será responsável por gerenciar esta comunicação, que será realizada através dos mais diversos tipos de veículos de divulgação que levem as informações a seus futuros clientes como anúncios em jornais, revistas, rádios, televisão, internet entre outros. A exposição de faixas e cartazes em concessionários, assim como a exposição de veículos com estas informações em supermercados e feiras de veículos também devem ser exploradas.

O tempo para a vigência desta campanha deve iniciar aproximadamente um mês antes do lançamento da garantia estendida ao mercado e vigorar durante seis meses no seu tempo total. 


\subsubsection{Segunda Fase - Vigência da Garantia de Dois Anos}

Embora já tenham sido comunicadas nas fases anteriores deste plano, os concessionários serão comunicadas novamente através de e-mails informativos sobre a data de início das vendas dos veículos que terão 24 meses de garantia.

A partir desta data será realizado um monitoramento constante dos veículos vendidos quanto ao seu comportamento, possíveis falhas e reclamações dos clientes.

\subsubsection{Monitoramento das Falhas Ocorridas em Durabilidade Durante o Segundo Ano de Garantia}

Com o objetivo de observar o comportamento dos veículos no segundo ano de garantia, será realizado um monitoramento das falhas que ocorram neste período.

Este trabalho será coordenado pelo departamento de Administração de Qualidade da empresa, que será responsável por realizar os levantamentos no banco de dados de falhas da empresa seguindo os critérios já mencionados, entrar em contato com os concessionários para obter maiores dados a respeito das falhas, e de posse desta informação, envolver os departamentos competentes para a definição da causa raiz dos problemas e que estes sejam de potencial risco para o sucesso do programa de garantia em 24 meses.

Este monitoramento será realizado permanentemente, desde o início do segundo ano da garantia, encerrando somente após o término do período de garantia para todos os veículos vendidos. 


\subsubsection{Tomada de Decisão Quanto à Extensão do Período de Garantia para Três Anos}

Em função da introdução progressiva da extensão do período de garantia para veículos populares, ao final do segundo ano de vigência de garantia é necessária a tomada de decisão da empresa para manter o período para três anos, mediante a observação das seguintes condições:

- O valor do custo de garantia por veículo real em 24 meses de exposição no campo deverá ser comparado junto ao valor teórico demonstrado no item 4.2, deste trabalho, devendo estar igual ou abaixo do projetado;

- Não deverão existir reclamações de clientes que impactem negativamente na imagem do produto e da empresa;

- Não poderão existir altas incidências de falhas neste período;

- Não deverão existir falhas que comprometam a segurança dos clientes.

\subsubsection{Terceira Fase - Vigência da Garantia de Três Anos}

A terceira fase deste plano contempla a garantia de três anos caso esta seja implementada pela empresa diante dos resultados obtidos nos dois primeiros anos de garantia.

A comunicação quanto à extensão do período de garantia para três anos em veículos populares será realizada da mesma forma como na primeira fase deste projeto, sem haver a necessidade de treinamento de funcionários da empresa e dos funcionários dos concessionários.

Será necessário ainda um monitoramento constante dos veículos vendidos quanto ao seu comportamento, possíveis falhas e reclamações dos clientes durante o terceiro ano em que vigorar a garantia dos primeiros veículos vendidos. 


\subsubsection{Monitoramento das Falhas Ocorridas Durante o Terceiro Ano de Vigência da Garantia}

Com o objetivo de monitorar o comportamento dos veículos no terceiro ano de garantia, será realizado um monitoramento das falhas que ocorram neste período.

Este trabalho será igualmente coordenado pelo departamento de Administração de Qualidade da empresa, executado da mesma forma como para com as falhas ocorridas durante o segundo ano em garantia como já detalhado no item 5.3.2.1.

Este monitoramento será realizado permanentemente, desde o início do terceiro ano da garantia, até que todos os veículos envolvidos tenham atingido três anos de permanência no campo.

\subsubsection{Tomada de Decisão Quanto à Manutenção do Período de Garantia para Três Anos}

Ainda como parte da introdução progressiva da extensão do período de garantia para veículos populares, ao final do terceiro ano de vigência de garantia, é necessária a tomada de decisão da empresa quanto à manutenção do período de garantia em três anos, mediante a observação das seguintes condições:

- O valor do custo de garantia por veículo real em 36 meses de exposição no campo deverá ser comparado junto ao valor teórico demonstrado no item 4.2 deste trabalho, devendo estar igual ou abaixo do projetado;

- Não deverão existir reclamações de clientes que impactem negativamente imagem do produto e da empresa;

- Não poderão existir altas incidências de falhas neste período;

- Não deverão existir falhas que comprometam a segurança dos clientes. 
O processo de voltar atrás em um aspecto relevante para a imagem da empresa como a diminuição do período de garantia pode ser doloroso, porém, se por ventura uma das condições não estiver sendo atendida será necessário retroceder à condição inicial de somente dois anos de garantia. Se todas as condições forem atendidas, é possível considerar o plano de implementação bem-sucedido como um todo, reconhecendo o esforço e comprometimento de todas as partes envolvidas neste processo e permitindo o encerramento de todas as atividades do plano de implementação.

Segue na Figura 14 abaixo o cronograma consolidado de todas as fases e atividades deste plano:

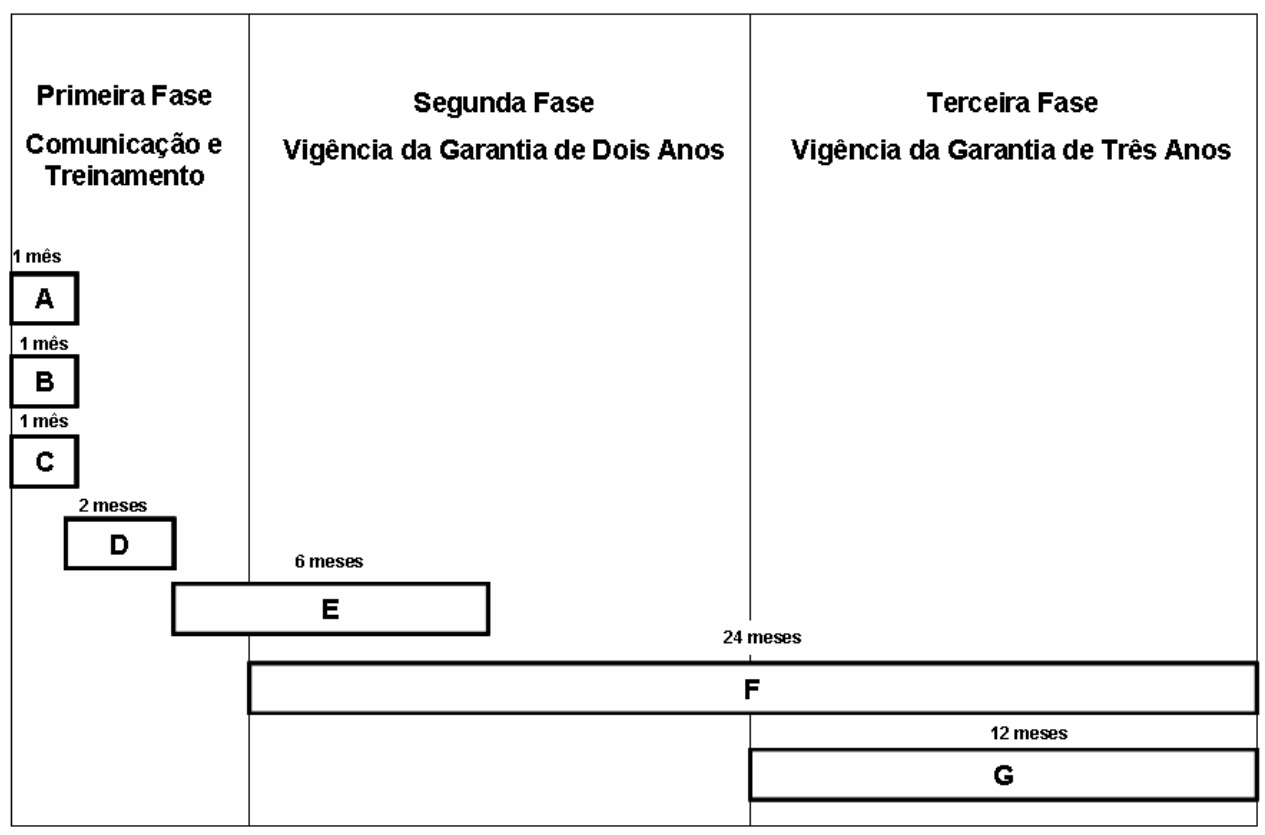

$A=$ Comunicação e Treinamento dos Funcionários da Empresa $E=$ Divulgação e Exposição na Mídia

$\begin{array}{ll}B=\text { Comunicação e Treinamento dos Fornecedores } & F=\text { Monitoramento das Falhas Ocorridas Durante o Segundo Ano da Garantia } \\ C=\text { Comunicação às Concessionárias } & G=\text { Monitoramento das Falhas Ocorridas Durante o Terceiro Ano da Garantia }\end{array}$

D = Treinamento dos Funcionários das Concessionárias

Figura 14 - Cronograma do Plano de Implementação da Extensão do Plano de Garantia Para 


\section{CONCLUSÕES E CONSIDERAÇÕES FINAIS}

Sob o prisma de gestão de garantia na empresa, verifica-se que a modalidade de garantia atualmente aplicada para o veículo é a explicita e incondicional, em que a prioridade é o foco na satisfação do cliente.

A política de substituição em garantia utilizada atualmente para o veículo popular na empresa é a política de substituição livre ilimitada, em que a empresa responsabiliza-se por todos os custos inerentes a reparo ou substituição dos componentes defeituosos dentro do período de garantia.

Assim, é recomendada a manutenção da garantia explícita e incondicional, além de manter a política substituição livre ilimitada para todos os componentes do veículo, inclusive aqueles que não estejam relacionados ao conjunto motor e transmissão.

Com a extensão do período de garantia em veículos populares, a empresa busca utilizar esta proposta como vantagem competitiva, aumentando assim a sua participação no mercado de veículos populares em um curto espaço de tempo.

A extensão da garantia para veículos populares ajudará também a consolidar a imagem da empresa no mercado como fornecedora de produtos de alta qualidade e robustez o que a fará diferenciar das outras empresas nos aspectos mercadológicos, aumentando assim a intenção de compra por parte do mercado consumidor para os produtos oferecidos pela empresa.

Outro ponto importante é que a empresa prestará o auxílio e serviços necessários aos clientes durante todo o tempo em que durar o período de garantia estendida, o que reforçará ainda mais a boa imagem da empresa no mercado.

A extensão do período de garantia reforçará a fidelização dos clientes à marca, por mantê-los em freqüente contato com os concessionários, o que proporciona oportunidades para a venda de serviços e acessórios em geral. 
Todos estes pontos devem ser explorados pelos departamentos de marketing e vendas da empresa, através da exposição das qualidades do produto em todas as formas de mídia, mostrando aos clientes todas as vantagens tangíveis ao adquirir um produto com alta qualidade e robustez, produzido e garantido por uma marca que tenha uma boa reputação e imagem no mercado brasileiro e que primará pelo bem estar de seus clientes em relação ao produto no período em que vigorar o período de garantia e colocando-se a disposição mesmo depois do término deste período.

O método para extensão do período de garantia para veículos populares apresentado neste trabalho mostrou-se apropriado e pode ser colocado em prática a qualquer momento, pois os dados de garantia, assim como os conceitos teóricos aplicados encontram-se a disposição para aplicação imediata deste estudo.

A possibilidade de utilizar dados que representam efetivamente a qualidade e confiabilidade da população de veículos em campo mostra-se como a maior vantagem do método aqui proposto, pois podem ser utilizados para a validação do plano de implementação da garantia estendida. Este método pode ser aplicado também com o propósito de obter a melhoria contínua do produto, com a utilização de peças atualizadas com o objetivo de monitorar a qualidade para o período de garantia desejado, desde que não afete a segurança do cliente.

Embora tenha sido apontada como uma vantagem, a utilização do banco de dados de falhas de campo requer uma atenção especial por parte da empresa junto aos concessionários e respectivos departamentos de garantia, pois este permite uma sucessão de erros em seu preenchimento, o que pode causar imprecisão nos dados utilizados e consequentemente um alto risco inerente nos processos de tomada de decisão empresarial.

Como principais desvantagens, os dados de garantia utilizados são restritos a somente 12 meses de exposição do veículo no campo, o que pode mascarar possíveis problemas com o tempo de vida útil de alguns componentes e diferentes modos de falha dos mesmos, quando considerados 36 meses de garantia. 
Outro ponto importante refere-se à utilização do Fator de Conversão (FC) de 24 para 36 meses. $\mathrm{O}$ valor utilizado $(\mathrm{FC}=1,32)$ tendo como referência o mercado britânico, pode ser alterado de acordo com os primeiros resultados do plano de validação da extensão de garantia proposto neste estudo. Porém, como já exposto, dependendo do valor deste fator, o custo de garantia por veículo no período proposto pode tornar inviável a extensão da garantia para veículos populares.

O plano de validação com a utilização de amostras provenientes do campo de provas da empresa é fundamental para a viabilização da proposta de extensão de garantia em veículos populares, embora com o alto custo inerente à utilização de recursos técnicos e de pessoal, pois é a proposta que apresenta a maior viabilidade técnica com execução estimada no período de seis meses, com baixo risco quando comparada a todas as outras opções estudadas quanto à incerteza no tempo de execução e monitoramento das amostras.

Para a redução de todos os riscos envolvidos nesta proposta é recomendada a introdução progressiva da extensa de garantia para veículos populares oferecendo primeiramente dois anos de garantia aos clientes e ao final deste período, se comprovada a eficiência da prática deste método, o mesmo critério pode ser aplicado para a extensão do período de garantia para veículos populares para três anos.

Para a empresa, além dos benefícios de vendas e marketing, a extensão do período de garantia para veículos populares permitirá que se conheçam as novas necessidades dos clientes através do maior tempo de relacionamento que terão durante o período proposto, redefinindo assim a necessidade de treinamento interno em todos os níveis operacionais e a redefinição dos papéis e responsabilidades de todos os membros da organização ao agregar o valor necessário às atividades que serão incorporadas nesta nova modalidade de garantia.

Finalmente, a extensão do período de garantia de veículos populares permitirá à empresa, baseada na retroalimentação por parte dos seus clientes, identificar e corrigir as falhas, melhorando os seus produtos correntes, inclusive aqueles que ainda estão por serem lançados no mercado no futuro. 


\section{ANEXO A}

\section{Plano de Verificação de Componentes nas Inspeções Periódicas}

\begin{tabular}{|c|c|}
\hline Grupo & Descrição \\
\hline \multirow{11}{*}{ Motor e Transmissão } & Verificar possíveis vazamentos. \\
\hline & Verificar o estado das velas de ignição. \\
\hline & $\begin{array}{l}\text { Verificar o estado da correia } \\
\text { dentada da distribuição. }\end{array}$ \\
\hline & Verificar correias de acessórios. \\
\hline & Verificar filtro de óleo. \\
\hline & Verificar filtro de ar. \\
\hline & $\begin{array}{l}\text { Verificar filtro de combustível externo } \\
\text { ao tanque. }\end{array}$ \\
\hline & Verificar pré-filtro de combustível. \\
\hline & $\begin{array}{l}\text { Verificar sistema de arrefecimento } \\
\text { quanto a possíveis vazamentos. }\end{array}$ \\
\hline & Verificar o nível da caixa de mudanças. \\
\hline & $\begin{array}{l}\text { Verificar quanto a teste de emissão de } \\
\text { poluentes. }\end{array}$ \\
\hline \multirow{4}{*}{ Freios } & Verificar quanto a desgaste nas pastilhas de freio. \\
\hline & Verificar quanto a desgaste nas lonas e tambores. \\
\hline & Verificar quanto a vazamento nas tubulações e mangueiras de freio. \\
\hline & Verificar freio de estacionamento. \\
\hline \multirow{6}{*}{ Direção e Suspensão } & Verificar quanto a evetuais vazamentos no sistema de direção hidraulica. \\
\hline & Verificar quanto a vazamentos e apertos no sistema de direção. \\
\hline & Verificar amortecedores \\
\hline & Verificar sistema de direção (caixa de direção). \\
\hline & Verificar guarnições e protetores de pó. \\
\hline & Verificar os pneus. \\
\hline \multirow{6}{*}{ Carroçaria } & Verificar o filtro de limpeza do condicionador de ar. \\
\hline & Verificar dobradiças, limitadores e fechaduras da porta e do motor. \\
\hline & Verificar drenos da parte inferior das portas. \\
\hline & Verificar fechaduras das portas. \\
\hline & Verificar quanto a danos de pintura e corrosão em toda a carroçaria. \\
\hline & $\begin{array}{l}\text { Verificar os cintos de segurança quanto ao estado de conservação dos cadarços, } \\
\text { torque dos parafusos de fixação e funcionamento. }\end{array}$ \\
\hline Embreagem & Verificar o curso livre do pedal. \\
\hline \multirow{3}{*}{ Elétrico } & Verificar equipamentos de iluminação e sinalização. \\
\hline & Verificar limpadores e lavadores do para-brisa. \\
\hline & $\begin{array}{l}\text { Analisar os códigos de falha do sistema elétrico arquivados na memória do ECM } \\
\text { (Engine Control Module) }\end{array}$ \\
\hline
\end{tabular}




\section{REFERÊNCIAS BIBLIOGRÁFICAS}

ALAVERDI, A.; FATHI N. Warranty Management: The Next Frontier in Cost Reduction and Product Quality Improvement. Disponível em http://www.warrantyweek.com/archive/ww20061003.html. Acesso em 31/10/2006

Anuário da Indústria Automotiva Brasileira. Publicado pela Associação Nacional dos Fabricantes de Veículos Automotores - ANFAVEA (2006). 167p.

BARKAI J.; Quality Improvement And Warranty Cost Containment: Better Answers Are In the Text, SAE 2666, 2004.

BAXTER, A. L..; TORTORELLA, M., Dealing with Real Field Reliability Data: Circumventing Incompleteness by Modeling \& Interaction. In: Proceeding Annual Reliability and Maintainability Symposium , 1984, p. 55-261.

BLASHE, M. K.; SHRIVASTAVA, B. A., Defining Failure of Manufacturing \& Equipment. In: Proceeding Annual Reliability and Maintainability Symposium , 1991, p. 326-329.

BERKE T.; ZAINO, A. N. Warranties: What Are They? What do They Really Cost? In: Proceeding Annual Reliability and Maintainability Symposium, 1991, p. 326-329.

BRALL A., A Model for Success in Implementing an R\&M Program by a Supplier of Manufacturing Machinery. In: Proceeding Annual Reliability and Maintainability Symposium , 1994, p. 59-64.

BRUSH, G. G.; How to Choose The Proper Sample Size. American Society for Quality Control. Milwaukee, Wisconsin, 1988. 115 p.

CHATERJEE S. et al, Delivery Guarantees and the Interdependence of Marketing and Operations, 2003. Disponível em http://www.findarticles.com/p/articles/mi qa3796/is 200210/ai n9087777. Acesso em $\underline{26 / 12 / 2006 .}$

COLOSIO, M. A.; ANDRADE, A. H. P.; SANTOS, J. C., Overview of Automotive Component Failures, SAE 3231, 2000. 
FIGUEIREDO, R., A Garantia Como Ferramenta de Gestão na Indústria Eletroeletrônica de Consumo, Dissertação (Mestrado em Administração), Universidade Federal do Rio de Janeiro, Brasil, 2005. 105 p.

GENERAL MOTORS DO BRASIL LTDA. Cinco Minutos da Qualidade. São Paulo: 2005. $10 \mathrm{p}$.

GIPA - Grupo Interprofissional de Produtos e Serviços Automóvel. Pesquisas Motoristas 2006. Relatório Interno.

HANSEN K. C.; THYREGOD P., Analysis of Contaminated Field Failure Data for Repairable Systems, In Proceeding Annual Reliability and Maintainability Symposium, 1991, p 604-609.

HUANG, Y \& ZHUO F., Estimation of Future Breakdowns to Determine Optimal Warranty Policies for Products with Deterioration. In Reliability Engineering \& System Safety. v. 84, n2. Maio 2004, p 163-168. Disponível em:http://www.sciencedirect.com/science?_ob=ArticleURL\&_udi=B6V4T-

4B84YRX2\&_user $=107229 \&$ coverDate $=05 \% 2 F 31 \% 2 F 2004 \&$ rdoc $=1 \&$ fmt $=$ \&_orig $=$ search\&_sort $=d \& v i e w=c \&$ acct $=C 000008279 \&$ version $=1 \&$ urlVersion=0\&_userid $=$

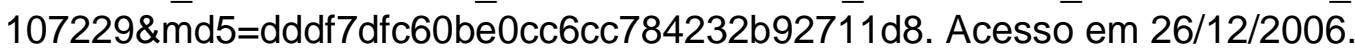

KOTLER, P., Administração de Marketing: A Edição do Novo Milênio. Tradução Bázan Tecnologia e Linguística. Revisão Técnica Arão Shapiro. São Paulo. Editora Prentice Hall, 2000.

LAMOTHE, C. P., Red X Strategies Pocket Guide, Second Edition. General Motors Corporation, 2002. $141 \mathrm{p}$.

LEI 8078/90, Código de Proteção e Defesa do Consumidor. Editora Saraiva. São Paulo. 2004.

MAJESKE D. K.; HERRIN D. G., Assessing Mixture Model Goodness of fit With An Application to Automobile Data, In: Proceeding Annual Reliability and Maintainability Symposium, 1995, p. 378-383.

Martha de Souza, G. F.: Confiabilidade de Produtos e Sistemas. (2003) Notas de Aula.

MARTHA DE SOUZA, G. F.: Confiabilidade de Produtos e Sistemas. (2003) Notas de Aula 
MICHAELIS: Minidicionário Escolar da Língua Portuguesa - São Paulo: Companhia Melhoramentos. 2000.

MIL-STD-781D, Reliability Testing for Engineering, Qualification, and Production, Department of Defense, Washington DC. 1986. Disponível em http://www.weibull.com/mil std/mil std 781d.pdf. Acesso em 03/01/2007.

MURAD, C. A., Extensão da Garantia de Veículos: Aplicação para Motor e Transmissão, Dissertação (Mestrado Profissionalizante), Escola Politécnica, Universidade de São Paulo, Brasil, 2005. 165 p.

MUTTLER D. R., A Study of How to Reduce Audio Warranty Costs While Maintaining Limited Engineering Resources, SAE 981151, 1998.

NASSER, A. L.; DEY, A.; TRYON, R., Simulation Tool for Predicting Warranty and Total Ownership Cost, SAE 0338, 2002.

O'CONNOR, P. D. T.: Practical Reliability Engineering, New York. Editora John Wiley \& Sons, 1988.

2002. $513 \mathrm{p}$.

: Practical Reliability Engineering, New York. Editora John Wiley \& Sons,

ROBINSON, P. E. \& OKOGBAA O. G., Post Warranty Distribution; A New Approach to Modeling the Reliability of Products with Built-In Obsolescence, SAE 2861 (1999).

SPRAKER G., Warranty Financial Management: Part 1: Defining Warranty Expense Management. Disponível em http://www.warrantyweek.com/archive/ww20060912.html. Acesso em 31/10/2006.

VENTURA, V. P.; VARIN, C., Development I Process and Cost Reduction Tool Application to Optimize Variable Cost on Vehicles, SAE 3448, 2002. WOLTEREC, M.; JUNG, C.; GUNTER R., How to Achieve Functional Safety and What Safety Standards and Risk Assessment Can Contribute, SAE 1662, 2004.

WIRTZ, J., Development of a Service Guarantee Model. Asia Pacific Journal of Management, v. 15, n. 1, p. 84-102, 1998. 
WOLTEREC, M.; JUNG, C.; GUNTER R., How to Achieve Functional Safety and What Safety Standards and Risk Assessment Can Contribute, SAE 1662, 2004. 